\title{
REVIEW
}

\section{Lipid storage in marine zooplankton}

\author{
Richard F. Lee ${ }^{1, *}$, Wilhelm Hagen ${ }^{2}$, Gerhard Kattner ${ }^{3}$ \\ ${ }^{1}$ Skidaway Institute of Oceanography, 10 Ocean Science Circle, Savannah, Georgia 31406, USA \\ ${ }^{2}$ Marine Zoologie, Universität Bremen (NW2), Postfach 330440, 28334 Bremen, Germany \\ ${ }^{3}$ Alfred-Wegener-Institut für Polar- und Meeresforschung, Postfach 120161, 27515 Bremerhaven, Germany
}

\begin{abstract}
Zooplankton storage lipids play an important role during reproduction, food scarcity, ontogeny and diapause, as shown by studies in various oceanic regions. While triacylglycerols, the primary storage lipid of terrestrial animals, are found in almost all zooplankton species, wax esters are the dominant storage lipid in many deep-living and polar zooplankton taxa. Phospholipids and diacylglycerol ethers are the unique storage lipids used by polar euphausiids and pteropods, respectively. In zooplankton with large stores of wax esters, triacylglycerols are more rapidly turned over and used for short-term energy needs, while wax esters serve as long-term energy deposits. Zooplankton groups found in polar, westerlies, upwelling and coastal biomes are characterized by accumulation of large lipid stores. In contrast, zooplankton from the trades/tropical biomes is mainly composed of omnivorous species with only small lipid reserves. Diapausing copepods, which enter deep water after feeding on phytoplankton during spring/summer blooms or at the end of upwelling periods, are characterized by large oil sacs filled with wax esters. The thermal expansion and compressibility of wax esters may allow diapausing copepods and other deep-water zooplankton to be neutrally buoyant in cold deep waters, and they can thus avoid spending energy to remain at these depths. Lipid droplets are often noted in zooplankton ovaries, and a portion of these droplets can be transferred to developing oocytes. In addition to lipid droplets, zooplankton eggs have yolks with lipovitellin, a lipoprotein with approximately equal amounts of protein and lipid. The lipovitellin lipid is predominantly phosphatidylcholine, so during reproduction females must convert a portion of their storage lipid into this phospholipid. Developing embryos use their lipovitellin and lipid droplets for energy and materials until feeding begins. The various functions storage lipids serve during the different life history stages of zooplankton are very complex and still not fully understood and hence offer a multitude of fascinating research perspectives.
\end{abstract}

KEY WORDS: Zooplankton · Lipids · Wax esters · Triacylglycerols · Diapause · Reproduction · Ontogeny $\cdot$ Biomes

Resale or republication not permitted without written consent of the publisher

\section{INTRODUCTION}

This review will concentrate on the accumulation and utilization of storage lipids by zooplankton from different ocean biomes. Storage lipids provide energy for reproduction, periods of low food supply, obtaining food, escaping predation and for vertical migration. The high-energy content of lipids (ca. $39 \mathrm{~kJ} \mathrm{~g}^{-1}$ ) offers an advantage over proteins and carbohydrates (both ca. 17 to $18 \mathrm{~kJ} \mathrm{~g}^{-1}$ ). We will discuss various types of storage lipids in different tissues, including dietary markers, and techniques used for lipid quantification.
Lipids are also important components of membranes (phospholipids, cholesterol), as hormones regulating various processes (ecdysone), as antioxidants (tocopherol, pigments) and for buoyancy (neutral lipids).

One of the earliest mentions in the scientific literature of zooplankton lipid accumulation is a description by Claus (1863) of the fat sac and fat droplets in the copepod Calanus sp. collected from the island of Helgoland, Germany. Seventy years later Marshall et al. (1934) described the buildup of lipids in C. finmarchicus copepodite stage 5 and adults associated with a spring phytoplankton bloom off the coast of Scotland. 
Lovern (1935) reported high amounts of lipid and longchain alcohols in $C$. finmarchicus from the North Sea, which suggested the presence of wax esters. In the 1950s and 60s there were several papers showing the accumulation of lipids by zooplankton, but these papers reported only total lipid and not the type of lipid present. Nakai (1955) and Blumer \& Mullin (1964) noted that lipid accounted for more than $50 \%$ of the dry mass (\%DM) of C. finmarchicus from the Gulf of Maine and C. cristatus from the North Pacific. Petipa (1964a) showed that the oil sac volume in C. helgolandicus in the Black Sea changed during diurnal migrations, while Ikeda (1974) described oil sacs with different shapes and sizes in copepods from various ocean biomes. Littlepage (1964) found lipid accumulation in the Antarctic euphausiid Euphausia crystallorophias in summer followed by utilization during the long dark Antarctic winter. Lee et al. (1970) reported that $C$. helgolandicus (= C. pacificus) from the California coast had high lipid contents, primarily wax esters contained within a prominent oil sac. Thus, there was good evidence by the 1970s that copepods, as well as other zooplankton groups, were able to accumulate large amounts of storage lipid.

A major part of this review will summarize the extensive studies over the past 3 decades showing the important role played by storage lipids in the life history of many zooplankton species, especially those from high latitudes. It is advantageous, particularly in herbivorous zooplankton from these oceanic areas, to accumulate large lipid stores during the relatively short phytoplankton blooms. The lipid stores can be utilized during the long winter, and for many species the storage lipid provides both energy and materials for reproduction before the onset of the spring phytoplankton bloom. Longhurst (1998) divided the ocean into 4 major biomes, referred to as polar, westerlies, trades/tropical and coastal biomes. Herbivorous copepods from polar and westerlies biomes go through a fall and winter diapause at great depths and use accumulated lipid stores, largely wax esters, for energy and reproductive needs. Because of their thermal expansion and compressibility properties, wax esters have an advantage for zooplankton in cold deep water (Yayanos et al. 1978, Køgeler 1987, Visser \& Jónasdóttir 1999). Owing to these properties, zooplankton with large stores of wax esters become neutrally buoyant in cold deep water, so energy is not required to maintain them at these depths. In upwelling coastal biomes herbivorous copepods diapause at depths during nonupwelling periods. Until upwelling returns these diapausing copepods utilize wax ester stores. Instead of lipid accumulation in the late stages, some copepod species form diapause eggs during low food periods (Marcus 1996 and references therein). In contrast to species from high latitudes or upwelling areas, zooplankton from tropical biomes generally do not accumulate large lipid stores; however, lipid droplets have been noted in gonads of tropical copepods. Gelatinous zooplankton species belonging to the phyla Cnidaria, Ctenophora and Tunicata do not accumulate large lipid stores, and extensive feeding results in rapid growth, but not in lipid accumulation (Madin et al. 1981, Youngbluth et al. 1988, Deibel et al. 1992, Nelson et al. 2000, Ju et al. 2004), although there may be exceptions in polar regions (Falk-Petersen et al. 2002).

While freshwater zooplankton are not covered in this review, there are studies showing the importance of storage lipids, both triacylglycerols and wax esters, for reproduction, growth and survival of zooplankton in freshwater ecosystems (Tessier \& Goulden 1982, Boudier \& Amblard 1989, Cavaletto et al. 1989, Butler 1994, Brett \& Müller-Navarra 1997, Vanderploeg et al. 1998, Ackman 1999, Arts 1999).

\section{TECHNIQUES FOR ANALYZING STORAGE LIPIDS}

\section{Chemical analysis}

Many analytical methods have been described for the characterization of lipids. Therefore, we only briefly touch this topic in our review. Zooplankton storage lipids are extracted along with other lipids by organic solvents, e.g. methanol and chloroform (more recently the less toxic dichloromethane), mostly based on procedures of Folch et al. (1957) or Bligh \& Dyer (1959). After extraction the different lipid classes can be separated by silicic acid thin-layer chromatography and quantified by thin-layer chromatography-densitometry methods (Armenta 1964, Sargent et al. 1977, Olsen $\&$ Henderson 1989). Another approach used to quantify the different types of lipids is the thin-layer chromatography/flame-ionization detection (TLC-FID) method (Ackman 1981, Parrish \& Ackman 1983, 1985, Fraser et al. 1985, Volkman et al. 1986, Parrish 1987 , 1999, Bergen et al. 2000, Hagen 2000). In this method lipid extracts are applied to quartz rods coated with a thin layer of silica, and the passage of solvent mixtures separates different lipid classes, which are quantified with a flame ionization detector. Separation by silicic acid column chromatography with gravimetrical quantification and confirmation of lipid classes by nuclear magnetic resonance (NMR spectroscopy) is used by Saito \& Kotani (2000). Separation and quantification of lipids has also been carried out by high performance liquid chromatography (HPLC) combined with evaporative light-scattering detection (Christie 1997, Nordbäck \& Lundberg 1999). A spectrofluorometric method has been developed, which allows quantitation of 
neutral and polar lipids after water extraction of tissues (Hentschel 1998, Alonzo \& Mayzaud 1999).

Collection of lipid classes from silicic acid columns or silicic acid thin-layer plates can be followed by analysis of constituent fatty acids and fatty alcohols. The derivatives of fatty acids and fatty alcohols can be analyzed by gas-liquid chromatography using capillary columns and flame ionization detection. Kattner \& Fricke (1986) developed a procedure in which fatty acid methyl esters and free alcohols are simultaneously analyzed. A suite of authentic standard fatty acids and alcohols are used to help in the identification of the individual fatty acids and alcohols. Gas-liquid chromatography-mass spectrometry (GC-MS) allows structural confirmation of fatty acids, fatty alcohols, 1-alkylglycerols and double-bond positions (for GC and GC-MS techniques see Lee et al. 1971b, Christie 1982, 1989, Kattner \& Fricke 1986, Tande \& Henderson 1988, Kattner et al. 1998 as well as many other references on slightly modified methods). Intact wax esters not hydrolyzed to constituent fatty acids and alcohols are applied to gas-liquid chromatography to determine the total chain length and structure of the wax esters (Lee et al. 1971b, 1974, Kattner et al. 1990). For example, major wax esters of the Arctic copepod Calanus hyperboreus were 40:2,42:2 and 44:2, which are composed of 20:1 and 22:1 fatty acids combined with the corresponding alcohols (Graeve \& Kattner 1992).

\section{Microscopic analysis}

Because many copepods have oil sacs filled with storage lipids, several techniques have been developed to quantify the oil volume under the microscope. Petipa (1964b) determined oil sac volumes and oil mass, assuming lipid density of $0.91 \mathrm{~g} \mathrm{ml}^{-1}$, in Calanus helgolandicus from the Black Sea. Using this technique she noted large increases in oil sac lipid mass from 0.6 to $45.4 \mu \mathrm{g}$, when copepodids developed from stage 2 to 5. Miller et al. (1998) quantified the oil sac volume of $C$. finmarchicus using a video image of live animals and found that storage lipid determined by the TLC-FID method correlated well with oil sac volume. Corkett \& McLaren (1969) developed an oil sac index to indicate the amount of assimilable food available to Pseudocalanus spp. with a calibration curve based on laboratory studies, where copepods were fed on different food concentrations. As Pseudocalanus spp. was fed increasing concentrations of phytoplankton food, there was a corresponding increase in the oil sac index (Corkett \& McLaren 1978). Oil sac volumes in Pseudocalanus spp. collected in the North Atlantic (Scotian shelf) were related to recent trophic history (Reiss et al. 1999). Paffenhöfer \& Harris (1976) noted well- developed oil sacs in copepodids and adults of Pseudocalanus spp. at food concentrations of 50, 100 and $200 \mu \mathrm{g}$ carbon $\mathrm{l}^{-1}$, but no evidence of oil sacs at a food concentration of $25 \mu \mathrm{g}$ carbon $\mathrm{l}^{-1}$. The seasonal moulting pattern of $C$. finmarchicus has been related to body size and oil sac volume (Arashkevich et al. 2004)

Many zooplankton species fed high food amounts do not develop well-defined oil sacs but rather accumulate oil droplets. Costlow (1982) suggested that the lipid reserves in barnacle nauplii could be estimated from the total volume of the 'oil cells', which were attached to the outer surface of the midgut. Goulden \& Hornig (1980) counted the number and size of oil droplets in a freshwater daphnid. Arts \& Evans (1991) developed a simple optical-digital method, which was used to follow changes in seasonal patterns of lipid droplets, i.e. triacylglycerols, in the freshwater copepod Diaptomus sicilis. Lipid-specific staining in combination with microscopy/photometry has been used to quantify storage lipid in zooplankton larvae derived from benthic adults, such as barnacle nauplii and bivalve veligers (Gallager \& Mann 1981, 1986). Some of the stains which can be used for such studies include Oil Red O, Sudan IV, Sudan Black B, Phosphine 3R and Nile Red (Croll 1972a,b, Gallager \& Mann 1981, 1986, Carman et al. 1991, Locke \& Sprules 1993).

\section{TYPES OF STORAGE LIPIDS}

\section{Lipid classes}

Four principal types of storage lipid have been found in marine zooplankton: triacylglycerols, wax esters, phospholipids and diacylglycerol ethers (1-alkyldiacylsn-glycerols) (Fig. 1). Triacylglycerols, composed of a glycerol backbone esterified with 3 fatty acids, are the most common storage lipid in animals. While triacylglycerols are present in almost all zooplankton, wax esters are major storage lipids in high-latitude species. Wax esters consist of simple esters of long-chain primary alcohols and long-chain fatty acids. The nomenclature used here for alcohols and fatty acids gives the carbon length, the number of double bonds and the position of the first double bond in relation to the terminal methyl group.

Phospholipids are a key component of biomembranes. In zooplankton these polar lipids consist of 3 major fatty acids, 22:6 (n-3), 20:5 (n-3) and 16:0, largely independent of dietary changes (Lee et al. 1971b, FalkPetersen et al. 2000). However, one of the important phospholipids, phosphatidylcholine, also appears to serve as a storage lipid in high-latitude euphausiids, e.g. Euphausia superba, E. crystallorophias and Thysanoessa macrura (Hagen et al. 1996, Mayzaud 1997). 

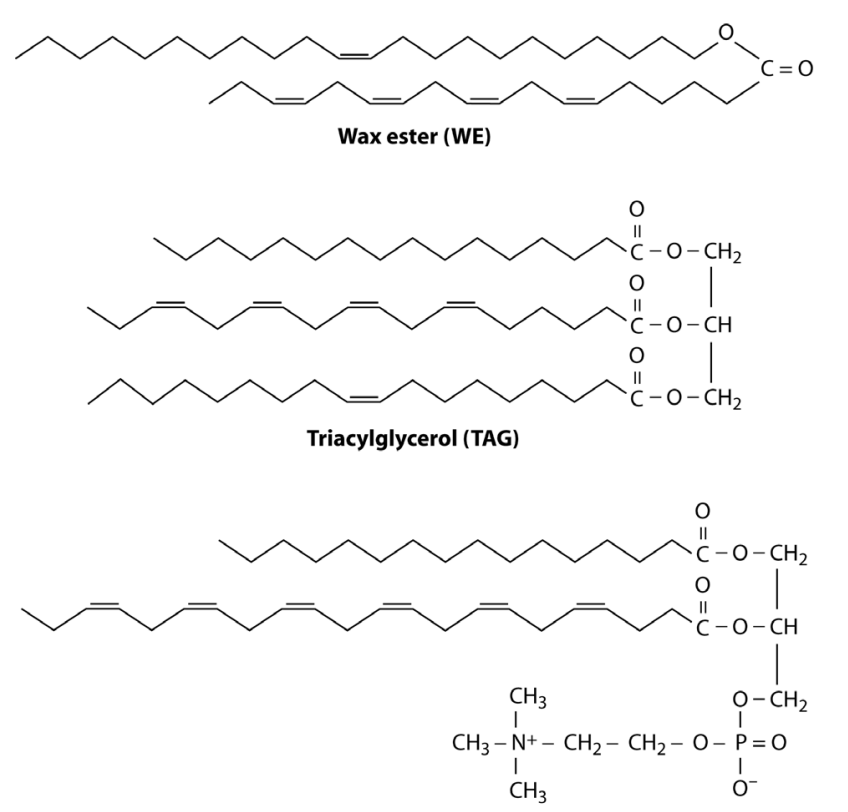

Phosphatidylcholine (PC)

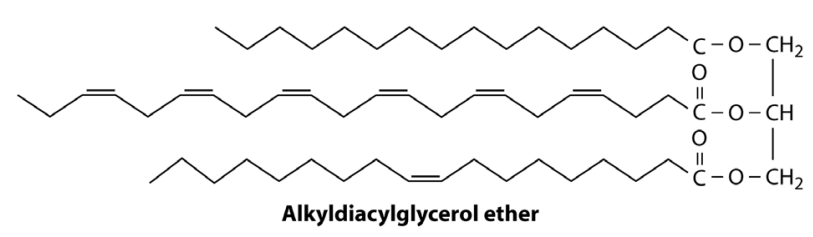

Fig. 1. Chemical structures of different storage lipids in zooplankton. Wax ester (22:1 alcohol; 18:4 fatty acid); triacylglycerol (16:0, 18:4 and 18:1 fatty acids); phosphatidylcholine (16:0 and 22:6 fatty acids); alkyldiacylglycerol ether (16:0 alcohol; 22:6 and 17:1 fatty acids)

Phosphatidylcholine is composed of a glycerol backbone with fatty acids at positions 1 and 2 and cholinephosphate on position 3. It is unusual for this lipid to serve for energy storage. This function is only suggested for phosphatidylcholine, but not for phosphatidylethanolamine, the other important marine zooplankton phospholipid. Membrane phospholipids generally have an asymmetric fatty acid distribution, where there is an unsaturated fatty acid at position 2 and a saturated fatty acid at position 1 (Hadley 1985). This asymmetric fatty acid distribution is thought to be of major importance in the functional and structural roles of membranes. Zooplankton phospholipids differ from this scheme since polyunsaturated fatty acids are in excess of saturates (Albers et al. 1996). Thus, polyunsaturated fatty acids are also in position 1, particularly 20:5(n-3) in phosphatidylcholine (Kattner 1991). Since the principal lipid of crustacean lipovitellin is phosphatidylcholine, we propose a possible transfer of phosphatidylcholine to euphausiid lipovitellin during reproduction.

The 4th type of storage lipid reported in marine zooplankton are diacylglycerol ethers, which have been reported as a major storage lipid in the pteropod genus Clione from polar and temperate regions (Lee 1974a, 1975, Phleger et al. 1997, Kattner et al. 1998, FalkPetersen et al. 2001, Böer et al. 2005). Up to $41 \%$ of the lipid of the pteropod C. limacina in polar oceans can be diacylglycerol ethers (Kattner et al. 1998). They are characterized by one ether-linked alkyl chain and 2 fatty acid esters at the glycerol backbone. These lipids are not found in the diet of this pteropod and are presumed to be made de novo from the diet, consisting exclusively of the pteropod Limacina helicina. The diacylglycerol ethers of $C$. limacina are unique with up to $1 / 3$ of their total fatty acids being odd-chain fatty acids, mainly 17:1(n-8), 15:0 and 17:0. It is not yet clear why pteropods store high amounts of diacylglycerol ethers with odd-chain fatty acids, in addition to the more commonly occurring triacylglycerols.

\section{Dietary fatty acids}

There is a large body of literature showing that fatty acid compositional changes can be used to determine the contribution of different microalgae groups in the food of herbivorous zooplankton and how these phytoplankton fatty acid patterns are modified in omnivorous and carnivorous zooplankton species (see the recent review by Dalsgaard et al. 2003). Since our review deals with storage lipids, we have restricted the discussion to fatty acids and fatty alcohols found in triacylglycerols and wax esters and how such compositional lipid data can be related to the diet. Principal fatty acids of triacylglycerols and fatty acids and alcohols of wax esters of selected copepods and euphausiids are presented in Tables $1 \& 2$.

Generally, phytoplankton fatty acids are incorporated unmodified into zooplankton storage lipids. The 16:1(n-7) and 20:5(n-3) are the principal diatom fatty acids (Kates \& Volcani 1966), while 18:4(n-3) and 22:6(n-3) are typical of dinoflagellates (Harrington et al. 1970, Graeve 1993). The presence of 16:1(n-7) and $18: 4(n-3)$ in storage lipids was used by Graeve et al. (1994b) and Scott et al. (1999) to indicate the relative importance of diatoms and dinoflagellates in the zooplankton diet. Other studies supported this observation, finding high concentrations of 16:1(n-7) and 18:4(n-3) in storage lipids of copepods and euphausiids after feeding in phytoplankton blooms, with 16:1 and 18:4 accounting for up to 45 and $23 \%$ of the total fatty acids, respectively (Sargent et al. 1985, Kattner \& Krause 1987, Kattner 1989, Norrbin et al. 1990, Kattner \& Hagen 1998, Miller et al. 1998, Falk-Petersen et al. 2000). The relatively high levels of $16: 4(n-1), 18: 4(n-3)$ and phytanic acid in the triacylglycerols of Euphausia superba have been used as an indicator of the impor- 
Table 1. Major fatty acids of storage lipids including wax ester alcohols in copepods from different biomes (mass\% of total fatty acids and alcohols, respectively). Neocalanus tonsus (Ohman et al. 1989), N. plumchrus (Lee 1974a, Lee \& Nevenzel 1979), other data from Albers et al. (1996). TAG = triacylglycerols; WE = wax esters

\begin{tabular}{|c|c|c|c|c|c|c|c|c|c|c|c|c|c|c|}
\hline & \multicolumn{2}{|c|}{$\begin{array}{l}\text { Calanoides } \\
\text { acutus } \\
\text { Antarctic }\end{array}$} & \multicolumn{2}{|c|}{$\begin{array}{l}\text { Metridia } \\
\text { gerlachei } \\
\text { Antarctic }\end{array}$} & \multicolumn{2}{|c|}{$\begin{array}{l}\text { Euchaeta } \\
\text { antarctica } \\
\text { Antarctic }\end{array}$} & \multirow{2}{*}{$\begin{array}{c}\text { Neocalanus } \\
\text { tonsus } \\
\text { Subantarctic } \\
\text { WE }\end{array}$} & \multicolumn{2}{|c|}{$\begin{array}{c}\text { Calanus } \\
\text { finmarchicus } \\
\text { Arctic }\end{array}$} & \multirow{2}{*}{$\begin{array}{c}\text { Metridia } \\
\text { longa } \\
\text { Arctic } \\
\text { WE }\end{array}$} & \multicolumn{2}{|c|}{$\begin{array}{c}\text { Calanus } \\
\text { hyperboreus } \\
\text { Arctic }\end{array}$} & \multicolumn{2}{|c|}{$\begin{array}{c}\text { Neocalanus } \\
\text { plumchrus } \\
\text { North Pacific }\end{array}$} \\
\hline & TAG & WE & TAG & WE & TAG & WE & & TAG & $\mathrm{WE}$ & & TAG & WE & TAG & WE \\
\hline \multicolumn{15}{|l|}{ Fatty acids } \\
\hline $14: 0$ & 8 & 4 & 13 & 1 & 13 & 1 & 14 & 12 & 26 & 1 & 7 & 6 & 8 & 11 \\
\hline $16: 0$ & 9 & 2 & 20 & 4 & 16 & 1 & 11 & 30 & 10 & 2 & 26 & 6 & 18 & 12 \\
\hline $16: 1(n-7)$ & 6 & 8 & 11 & 13 & 12 & 24 & 6 & 4 & 7 & 21 & 6 & 12 & 10 & 8 \\
\hline $16: 4(n-1)$ & 6 & 3 & 2 & 3 & 0.2 & 1 & - & - & 1 & 1 & - & 2 & 3 & 5 \\
\hline $18: 0$ & 1 & 4 & 4 & 0.3 & 2 & 0.2 & 2 & 6 & 1 & 1 & 12 & 1 & 7 & 0.2 \\
\hline 18:1(n-9) & 6 & 4 & 12 & 34 & 19 & 48 & $7^{a}$ & 10 & 5 & 30 & 18 & 6 & $8^{a}$ & $3^{a}$ \\
\hline $18: 1(n-7)$ & 1 & 1 & 6 & 1 & 9 & - & & 2 & 0.3 & 1 & 2 & 2 & & \\
\hline $18: 4(n-3)$ & 9 & 13 & 8 & 9 & 1 & 2 & 1 & 6 & 14 & 1 & 1 & 6 & 3 & 7 \\
\hline $20: 1(n-9)$ & 13 & 24 & 1 & 1 & 9 & 2 & 23 & - & 8 & 20 & 1 & 19 & 6 & 14 \\
\hline 20:5(n-3) & 15 & 17 & 9 & 17 & 4 & 8 & 5 & 9 & 11 & 7 & 2 & 7 & 17 & 21 \\
\hline 22:1(n-11) & 5 & 8 & 0.1 & - & 1 & 0.1 & 19 & 2 & 7 & 9 & - & 17 & & 9 \\
\hline $22: 6(n-3)$ & 9 & 6 & 6 & 8 & 3 & 7 & 2 & 6 & 2 & 1 & 3 & 2 & 2 & 2 \\
\hline \multicolumn{15}{|l|}{ Alcohols } \\
\hline $14: 0$ & & 11 & & 51 & & 64 & 1 & & 4 & 46 & & 4 & & 1 \\
\hline $16: 0$ & & 10 & & 46 & & 27 & 2 & & 15 & 18 & & 11 & & 5 \\
\hline $16: 1(n-7)$ & & 2 & & 4 & & 3 & 0.2 & & 3 & 1 & & 2 & & 7 \\
\hline 20:1(n-9) & & 56 & & - & & 4 & 57 & & 39 & 16 & & 28 & & 33 \\
\hline $22: 1(n-11)$ & & 21 & & - & & 1 & 25 & & 39 & 20 & & 55 & & 44 \\
\hline
\end{tabular}

Table 2. Major fatty acids of storage lipids including wax ester alcohols in euphausiids from different biomes (mass\% of total fatty acids and alcohols, respectively). Thysanoessa inermis collected during bloom conditions, Balsfjord, Norway (Falk-Petersen et al. 1990), T. inermis Kongsfjord, Svalbard (Falk-Petersen et al. 2000), Euphausia crystallorophias (Kattner \& Hagen 1998), E. superba

(Hagen et al. 2001), T. macrura (Hagen \& Kattner 1998), E. pacifica (Lee 1974a). TAG = triacylglycerols; WE = wax esters

\begin{tabular}{|c|c|c|c|c|c|c|c|c|c|c|c|c|c|}
\hline & \multirow{2}{*}{\multicolumn{2}{|c|}{$\begin{array}{c}\text { Thysanoessa } \\
\text { inermis } \\
\text { Northern Norway } \\
\text { Adults }\end{array}$}} & \multirow{2}{*}{\multicolumn{2}{|c|}{$\begin{array}{c}\text { Thysanoessa } \\
\text { inermis } \\
\text { Svalbard } \\
\text { Adults }\end{array}$}} & \multirow{2}{*}{\multicolumn{2}{|c|}{$\begin{array}{c}\text { Euphausia } \\
\text { superba } \\
\text { Antarctic } \\
\text { Furciliae Females }\end{array}$}} & \multicolumn{4}{|c|}{$\begin{array}{c}\text { Euphausia } \\
\text { crystallorophias } \\
\text { Antarctic }\end{array}$} & \multicolumn{2}{|c|}{$\begin{array}{c}\text { Thysanoessa } \\
\text { macrura } \\
\text { Antarctic }\end{array}$} & \multirow{3}{*}{$\begin{array}{c}\text { Euphausia } \\
\text { pacifica } \\
\text { North Pacific } \\
\text { Juveniles } \\
\text { TAG }\end{array}$} \\
\hline & & & & & & & \multicolumn{2}{|c|}{ Furciliae } & \multicolumn{2}{|c|}{ Adults } & Furciliae & Adults & \\
\hline & TAG & $\mathrm{WE}$ & TAG & WE & TAG & TAG & TAG & WE & TAG & WE & WE & WE & \\
\hline \multicolumn{14}{|l|}{ Fatty acids } \\
\hline $14: 0$ & 3 & 1 & 5 & 1 & 7 & 21 & 4 & 2 & 9 & 0.4 & 32 & 38 & 9 \\
\hline $16: 0$ & 29 & 4 & 30 & 3 & 27 & 23 & 10 & 5 & 19 & 1 & 23 & 26 & 18 \\
\hline $16: 1(n-7)$ & 8 & 4 & 30 & 14 & 5 & 9 & 9 & 5 & 15 & 8 & 5 & 6 & 13 \\
\hline $18: 0$ & 5 & 2 & 2 & 51 & 9 & 2 & 3 & 3 & 2 & 0.2 & 2 & 1 & 1 \\
\hline 18:1(n-9) & 10 & 59 & 8 & 14 & 8 & 24 & 13 & 34 & 20 & 65 & 11 & 17 & $12^{\mathrm{a}}$ \\
\hline $18: 1(n-7)$ & 11 & 10 & 13 & 3 & 3 & 6 & 6 & 16 & 7 & 20 & 3 & 5 & \\
\hline $18: 4(n-3)$ & 10 & 2 & 2 & 0.1 & 11 & 4 & 15 & 7 & 7 & 1 & 8 & - & 5 \\
\hline 20:1(n-9) & 1 & 2 & 1 & 2 & 3 & 1 & 4 & - & 1 & 3 & 6 & 1 & 0.2 \\
\hline 20:5(n-3) & 6 & 8 & 3 & 4 & 13 & 1 & 17 & 18 & 9 & 0.3 & 6 & 2 & 8 \\
\hline $22: 1(n-11)$ & 1 & 1 & 1 & 1 & - & - & 0.4 & - & 0.1 & - & - & 0.2 & - \\
\hline $22: 6(n-3)$ & 2 & 1 & 0.1 & 0.1 & 2 & 1 & 6 & 5 & 5 & 0.1 & 1 & 0.5 & 1 \\
\hline \multicolumn{14}{|l|}{ Alcohols } \\
\hline $14: 0$ & & 12 & & 22 & & & & 74 & & 63 & - & - & \\
\hline $16: 0$ & & 51 & & 58 & & & & 26 & & 34 & - & - & \\
\hline $16: 1(n-7)$ & & 4 & & 14 & & & & - & & - & - & - & \\
\hline $18: 1(n-9)$ & & - & & 0.1 & & & & - & & - & 40 & 40 & \\
\hline $18: 1(n-7)$ & & - & & 0.1 & & & & - & & - & 34 & 41 & \\
\hline 20:1(n-9) & & - & & 2 & & & & - & & 2 & 23 & 16 & \\
\hline $22: 1(n-11)$ & & - & & 2 & & & & - & & 0.2 & 1 & 4 & \\
\hline Phytol & & 23 & & - & & & & - & & - & - & - & \\
\hline
\end{tabular}


tance of diatoms in the diet of this Antarctic euphausiid (Clarke 1980, 1984, Clarke \& Morris 1983) (Table 2).

In zooplankton with large wax ester stores, the fatty acids of triacylglycerol may be more reflective of recent food, whereas wax ester fatty acids and alcohols reflect both dietary influences and de novo synthesis. Triacylglycerols are utilized more rapidly than wax esters, which serve as energy reserves during longer fasting periods. Assimilation of dietary fatty acids and de novo biosynthesis are rapid processes (Graeve et al. 2005). The wax esters of many herbivorous copepods are characterized by considerable amounts of the long-chain monounsaturated fatty acids 20:1(n-9), 20:1(n-11), and 22:1(n-11) (Tables 1 \& 2), which are not present in significant amounts in their phytoplankton diet. The 20:1 and 22:1 fatty acids are reduced to the corresponding alcohols, which are the principal alcohols of these zooplankters. Omnivorous and carnivorous zooplankton species are characterized by wax esters with high amounts of the 18:1(n-9) fatty acid (Tables 1 \& 2). Carnivorous zooplankton feeding on wax-ester-rich herbivorous copepods have triacylglycerols with high amounts of 20:1(n-9) and 22:1(n-11) fatty acids. These are assumed to be derived from the 20:1 and 22:1 alcohols and fatty acids in their copepod diet (Ackman et al. 1970, Ratnayake \& Ackman 1979a,b, Sargent \& Falk-Petersen 1981).

\section{Fatty alcohols}

Since wax esters are usually absent in marine phytoplankton lipids, wax ester alcohols in herbivorous zooplankton originate either from reduction of phytoplankton fatty acids or from de novo synthesis from phytoplankton protein and carbohydrate. The biosynthesis of fatty alcohols and esterification with a fatty acid to wax esters results in rapid lipid accumulation since there is both de novo synthesis and incorporation of dietary lipids (Sargent et al. 1981, Sargent \& Henderson 1986, Graeve et al. 2005).

There are major differences between the principal alcohols of different zooplankton species (Tables 1 \& 2). The most important wax ester alcohols are 14:0, $16: 0, \quad 18: 1(n-9), \quad 18: 1(n-7), 20: 1(n-9), 20: 1(n-11)$ and 22:1(n-11). The 20:1(n-9) and 22:1(n-11) are the most common alcohols of the wax esters found in herbivorous zooplankton, while omnivorous and carnivorous zooplankton have a predominance of 14:0 and 16:0 alcohols. However, in the Antarctic euphausiid Euphausia crystallorophias and the copepod Rhincalanus gigas, which are considered to be herbivorous or omnivorous, the 14:0 and 16:0 accounted for 90\% of the wax ester alcohols. It appears that the 20:1(n-9) and 22:1(n-11) alcohols only occur in copepods that undergo diapause (Graeve et al. 1994a, Kattner et al. 1994a, Kattner \& Hagen 1998). A principal wax ester alcohol of the north Atlantic euphausiids Thysanoessa raschii and T. inermis at one collection site in northern Norwegian waters was phytol, which was hypothesized to be due to feeding on phytoplankton detritus (Falk-Petersen 1981, Falk-Petersen et al. 1981, 1982, Sargent \& FalkPetersen 1981). However, T. raschii and T. inermis collected from another fjord did not have phytol in their wax esters (Table 2). In addition, E. crystallorophias also contained considerable amounts of phytol at one under-ice location in Antarctica (Falk-Petersen et al. 1999). The fatty alcohol composition of the Antarctic euphausiid Thysanoessa macrura is unique because it has both 18:1(n-9) and (n-7) as its principal alcohols (Kattner et al. 1996, Hagen \& Kattner 1998).

Kattner \& Krause (1989) reported 22:1 alcohol to account for 43 to $72 \%$ of the alcohols in Calanus finmarchicus from the North Sea, whereas Miller et al. (1998) reported an absence of this alcohol in C. finmarchicus from the Gulf of Maine. This is the only report where the 20:1 alcohol in herbivorous copepods was not accompanied by large amounts of the 22:1 alcohol.

\section{LIPID STORAGE IN DIFFERENT TISSUES}

Marine zooplankton accumulates storage lipids in oil sacs, oil droplets, hepatopancreas/fat bodies, digestive tracts and gonadal tissues. The location of storage lipids is best observed in photomicrographs of sections from fixed tissues.

\section{Oil sac}

Many species of the copepod genera Calanus, Euchaeta, Paraeuchaeta, Eucalanus, Rhincalanus and Pseudocalanus are characterized by large oil sacs that can occupy a large part of the body cavity. Ultrastructure studies have shown oil sacs filled with triacylglycerols or wax esters, to be surrounded by a single layer of epithelial cells (Figs. 2 \& 3a) (Lee et al. 1970, Benson et al. 1972, Bauermeister \& Sargent 1979, Henderson \& Sargent 1980, Blades-Eckelbarger 1991). In Euchaeta japonica the alimentary canal, which produces triacylglycerols, lies in close proximity to an oil sac containing only wax esters. Since membrane preparations from oil sacs of this copepod form wax esters from fatty acids, it seems likely that triacylglycerols formed in the alimentary canal are converted to wax esters by oil sac membrane cells (Henderson \& Sargent 1980). Similarly, Holtz et al. (1973) found that oil sac membrane cells from C. pacificus carried out wax ester synthesis. Sev- 

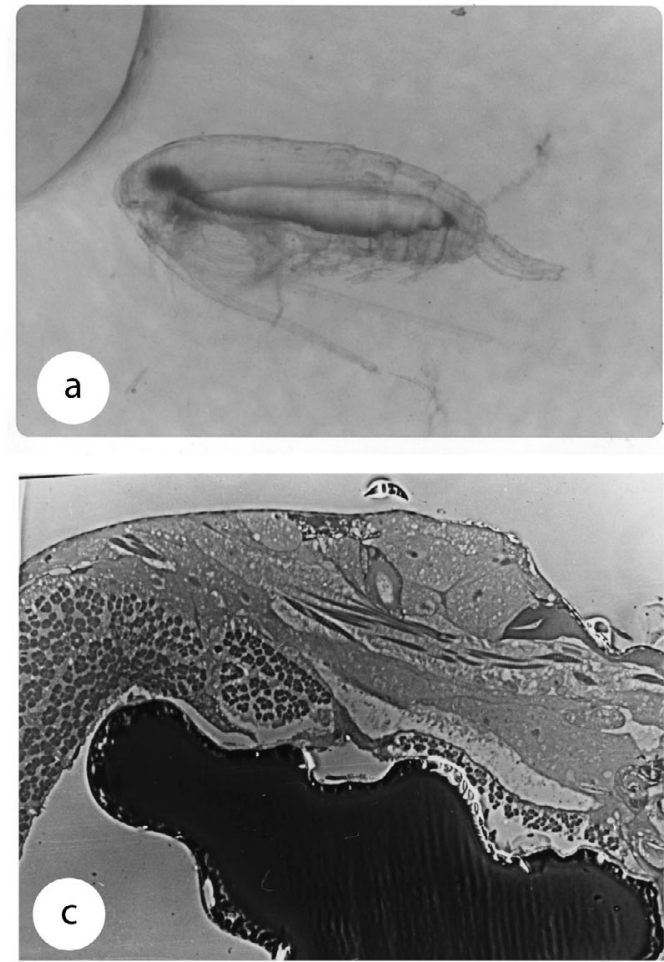
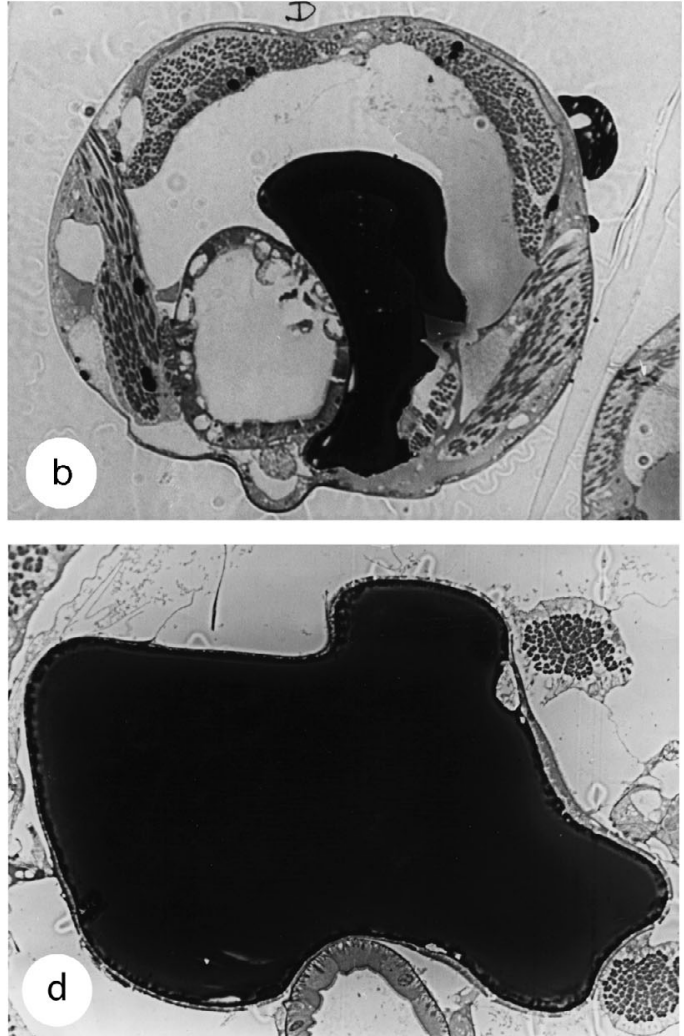

Fig. 2. Calanus plumchrus. (a) Photomicrograph of a living specimen with large oil sac; (b) section of fixed tissues from C5 with large dark oil sac adjacent to digestive lumen; (c) section showing large dark oil sac and adjacent muscle tissues; (d) electron micrograph showing membrane surrounding oil sac and section of lumen
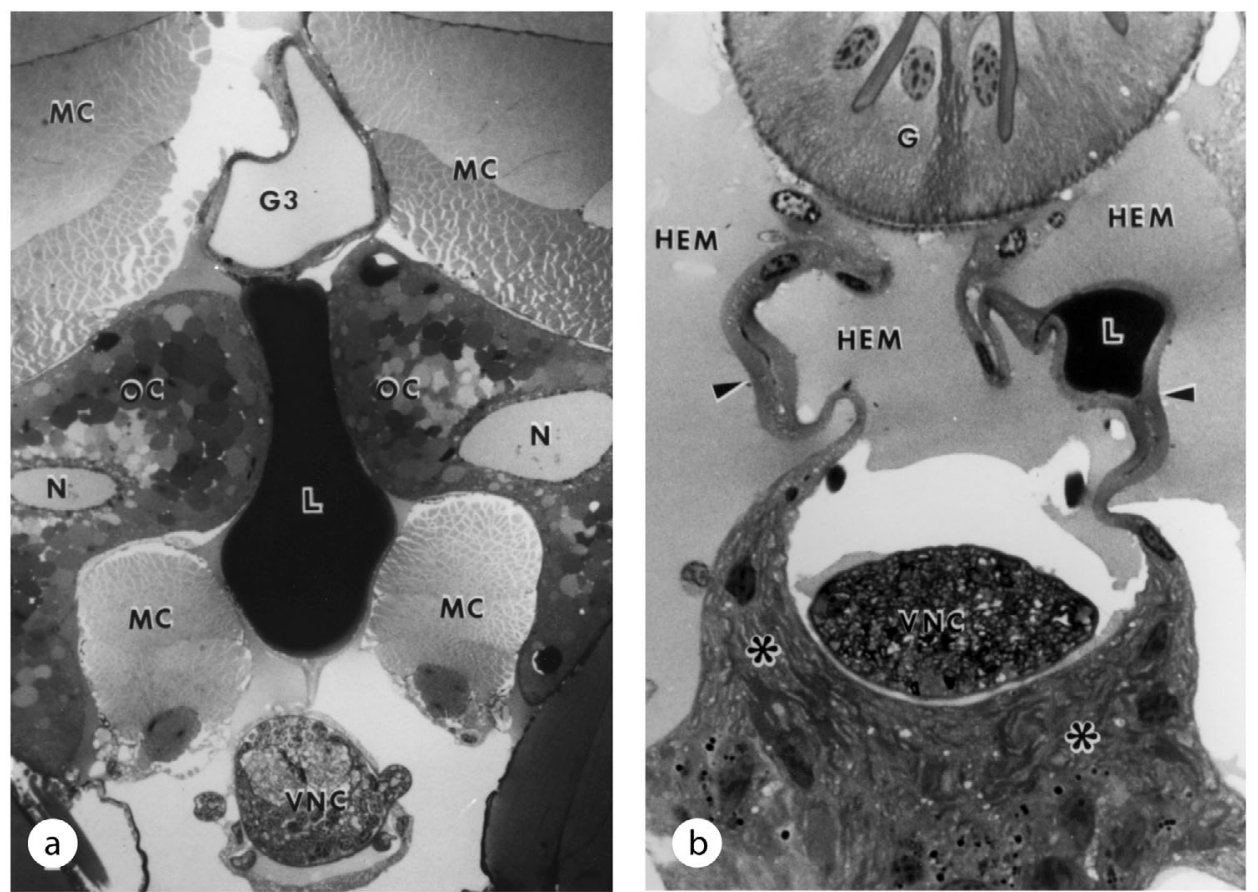

Fig. 3. Euchaeta marina from subtropical region of Gulf Stream. Light micrograph section showing (a) lipid sac (L), midgut (G3), musculature (MC), ventral nerve cord (VNC), oocytes (OC) with nucleus (N) (magnification 260×); (b) small lipid inclusion (L), midgut (G), ventral nerve cord (VNC) and hemolymph (HEM). Arrowheads indicate end of lipid sac; branches of the lipid sac extend around VNC and border on an unidentified gland (*). Lipid inclusion is closely connected to midgut and surrounded by hemolymph (magnification 600×). With permission from Blades-Eckelbarger (1991) 
eral investigators have commented on the similarity of copepod oil sacs to adipose tissue cells of higher vertebrates. Electron micrographs of oil sacs of Euchaeta norvegica and $C$. finmarchicus showed membranous structures within the oil sac. This led Sargent \& Henderson (1986) to conclude that copepod oil sacs are similar to higher animal adipose tissues, which are composed of adipocytes or fat cells. Blades-Eckelbarger (1986), based on light microscopy studies, suggested that the cells surrounding the oil sac in Euchaeta marina (Fig. 3b) resembled mammalian white adipose tissue cells. These oil sacs also show similarity to the adipocytes of fish tissues (Zhou et al. 1996).

During reproduction or periods of low food, oil sac wax esters or triacylglycerols are used for energy and materials. Blades-Eckelbarger (1991) noted the presence of micropinocytotic activity and invaginations along the membrane surrounding the oil sac, which along with many mitochondria suggested active lipid metabolism at the surface of the lipid in the oil sacs. In vertebrate animals a protein, perilipin, plays an important role in regulating utilization of triacylglycerol oil droplets in the adipocytes (Greenberg et al. 1991), and we suggest a perilipin-like protein may play a role in regulating storage and utilization of the storage lipids found in many zooplankton species.

\section{Oil droplets}

In addition to lipids within oil sacs, oil droplets and so-called lipid inclusions have been found distributed throughout the body cavity in zooplankton, particularly in those from higher latitudes and deeper waters (Figs. 3b \& 4) (Lee \& Hirota 1973, Bauermeister \& Sargent 1979, Defaye et al. 1985, Larson \& Harbison 1989, Blades-Eckelbarger 1991). Electron micrographs of these lipid droplets show the close proximity of mitochondria, suggesting that lipids within the droplets can be rapidly metabolized (Fig. 4b). In copepods with oil sacs filled with wax esters, the lipid droplets were found to be composed of triacylglycerols (Bauermeister \& Sargent 1979). Studies on copepods, where triacylglycerols and wax esters are spatially separated, have shown that triacylglycerols serve as rapidly used energy stores, while wax esters are more slowly used over longer periods (Lee et al. 1971a, Lee \& Barnes 1975, Håkanson 1984, Sargent \& Henderson 1986).

\section{Hepatopancreas and fat bodies}

The different cell types found in crustacean hepatopancreas tubules, including crustacean zooplankton, are E-, F-, R- and B-cells, where the F-, R- and B-cells are derived from embryonic or E-cells. The R-cells are the primary storage cells and can contain large accumulations of lipid droplets and lipoproteins (Arnaud et al. 1978, 1980, Halberg \& Hirche 1980, Robinson \& Dillaman 1985, Al-Mohanna \& Nott 1987, 1989, Sagrista \& Durfort 1991, Vogt 1994, Wright \& Ahearn 1997). Hepatopancreas or digestive glands of many zooplankton groups, including copepods and euphausiids, are characterized by lipid droplets and high lipid contents (Herring 1973, Raymont et al. 1974, Arnaud et al. 1980, Henderson et al. 1981, Sargent et al. 1981, Saether et al. 1983, Blades-Eckelbarger 1991, Virtue et al. 1993, Pond et al. 1995). The hepatopancreas of the euphausiid Thysanoessa inermis had a high wax ester content, possibly associated with lipid droplets (Sargent et al. 1981). For the decapod Notostomus auriculatus, $93 \%$ of the lipid in the animal's body is associated with the hepatopancreas (Herring 1973). In contrast, in Euphausia superba, less than $2 \%$ of its lipids are located in this organ (Clarke 1980).
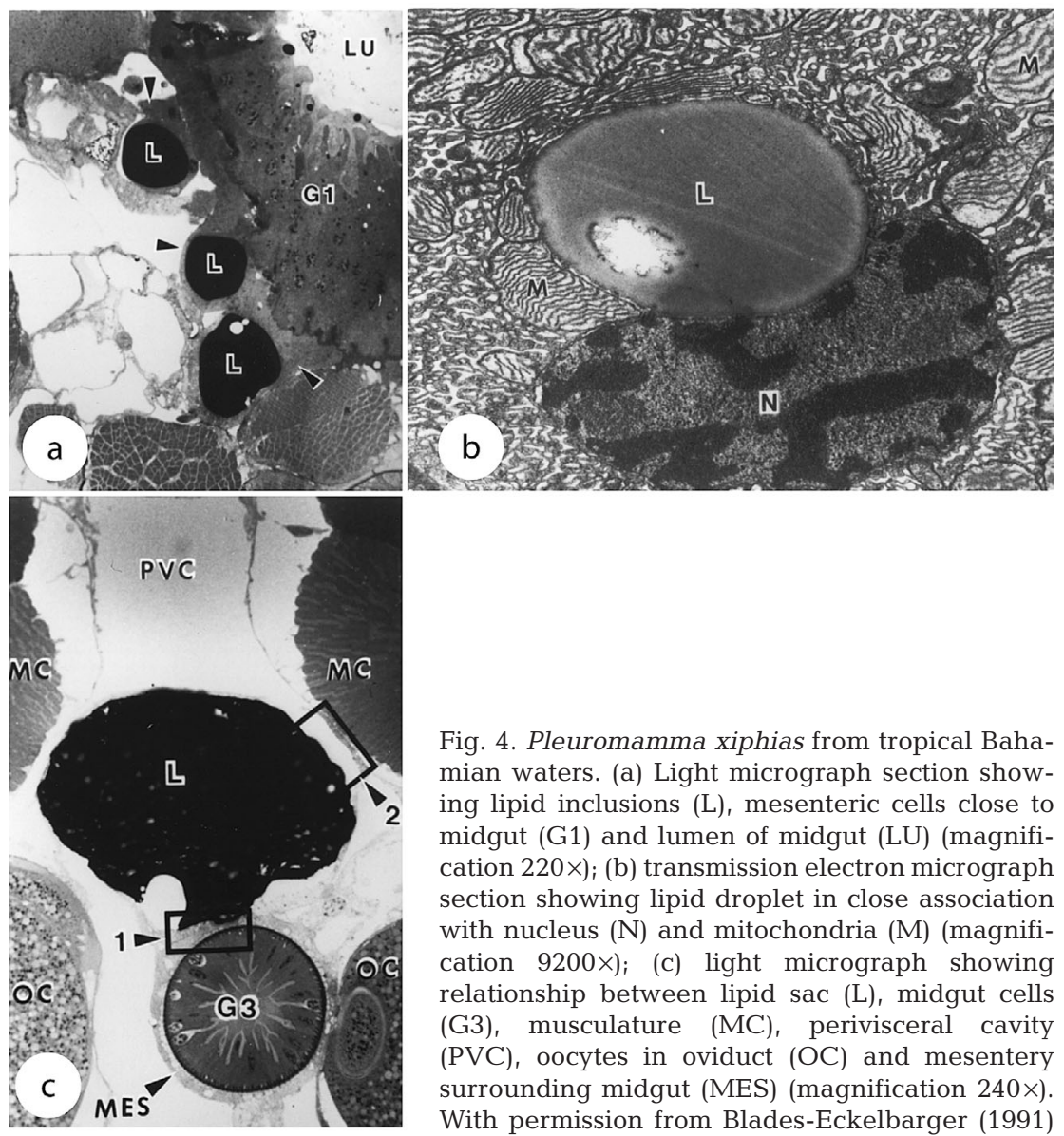

Fig. 4. Pleuromamma xiphias from tropical Bahamian waters. (a) Light micrograph section showing lipid inclusions (L), mesenteric cells close to midgut (G1) and lumen of midgut (LU) (magnification $220 \times)_{i}$ (b) transmission electron micrograph section showing lipid droplet in close association with nucleus $(\mathrm{N})$ and mitochondria $(\mathrm{M})$ (magnification 9200 $\times$ ); (c) light micrograph showing relationship between lipid sac (L), midgut cells (G3), musculature (MC), perivisceral cavity (PVC), oocytes in oviduct (OC) and mesentery surrounding midgut (MES) (magnification 240×). With permission from Blades-Eckelbarger (1991) 
Various polar euphausiids appear to utilize phosphatidylcholine as a storage lipid (Hagen 1988, Hagen et al. 1996, Mayzaud 1997). Phosphatidylcholine is the major lipid in high-density lipoproteins found in arthropod hemolymph (Lee \& Puppione 1988, Lee 1991, Walker et al. 2003). These lipoproteins play an important role in transporting lipids from different tissues, e.g. hepatopancreas/liver to muscle. Some euphausiids may store phosphatidylcholine in lipoproteins within a storage tissue. In vertebrates, liver parenchymal cells and the Golgi apparatus carry out the synthesis and assembly of plasma lipoproteins (Dolphin 1985, Havel 1987). In decapod crustaceans lipoproteins are assembled in the hepatopancreas (Walker et al. 2003), while in insects and isopods they are assembled in the fat body (Picaud 1980, Kanost et al. 1990).

Since the hepatopancreas of Euphausia superba is not an important tissue for lipid storage, other euphausiid tissues have been examined as lipid storage sites. Recently Stübing (2004) found evidence of phosphatidylcholine storage within the cephalothorax of E. superba, possibly within tissues similar to the fat bodies of insects and isopods. Phospholipid staining showed a relatively uniform distribution of phosphatidylcholine within the fat body cells. Sucrose gradients of extracts from E. superba indicated that much of the phosphatidylcholine was not associated with the membrane fraction but was found in a less dense supernatant fraction. One possibility is that phosphatidylcholine-rich lipoproteins accumulate in the cytosol of the euphausiid storage tissue. Since phosphatidylcholine is the principal lipid component of crustacean lipovitellin, phosphatidylcholine-rich particles in euphausiid storage tissues may be used in the assembly of E. superba lipovitellins for developing oocytes.

\section{Ovary}

Oil droplets, composed of triacylglycerols or wax esters, have been observed in ovarian sections of euphausiids and copepods (Fig. 5a) (Saether et al. 1983, Blades-Eckelbarger 1991). Oil sacs, when present, are often in close proximity to developing oocytes (Fig. 4c). Lipovitellin, the major constituent of yolks in crustaceans, polychaetes and molluscs, consists of 30 to $50 \%$ lipid. Lipovitellins are utilized for energy and materials by the newly hatched larvae. Phosphatidylcholine is generally the major lipid component of lipovitellin with lesser amounts of cholesterol and triacylglycerols (Lee 1991). In Artemia salina, and presumably in other crustacean zooplankton, the lipovitellin is associated with egg-yolk granules (deChaffoy \& Kondo 1980).

\section{ACCUMULATION AND UTILIZATION OF STORAGE LIPIDS}

\section{Reproduction}

A great deal of energy and materials are required for reproduction processes. After copepod reproduction is completed the female has a lower lipid content and smaller oil sac than the copepodite stage 5 (Figs. 6 \& 7). A feature of reproduction is the accumulation of lipid droplets and yolk lipovitellin in the developing ovary and oocytes (Fig. 5) (Hilton 1931, Ross et al. 1982, Blades-Eckelbarger \& Youngbluth 1984, Blades-Eckelbarger 1986, Cuzin-Roudy \& Amsler 1991, Ianora \& Santella 1991, Laabir et al. 2001). Lipovitellins are associated with yolk spheres or granules within the oocytes. Lipid droplets (wax esters or triacylglycerols) and lipovitellins are utilized by zooplankton embryos for energy, membranes and hormones (Lee \& Walker 1995). Females with large stores of wax esters or triacylglycerols convert a portion of these lipids into phospholipids, and these newly formed phospholipids are used to assemble lipovitellin in the developing oocytes. A schematic diagram is presented in Fig. 6 showing a female copepod with a large oil sac produc-

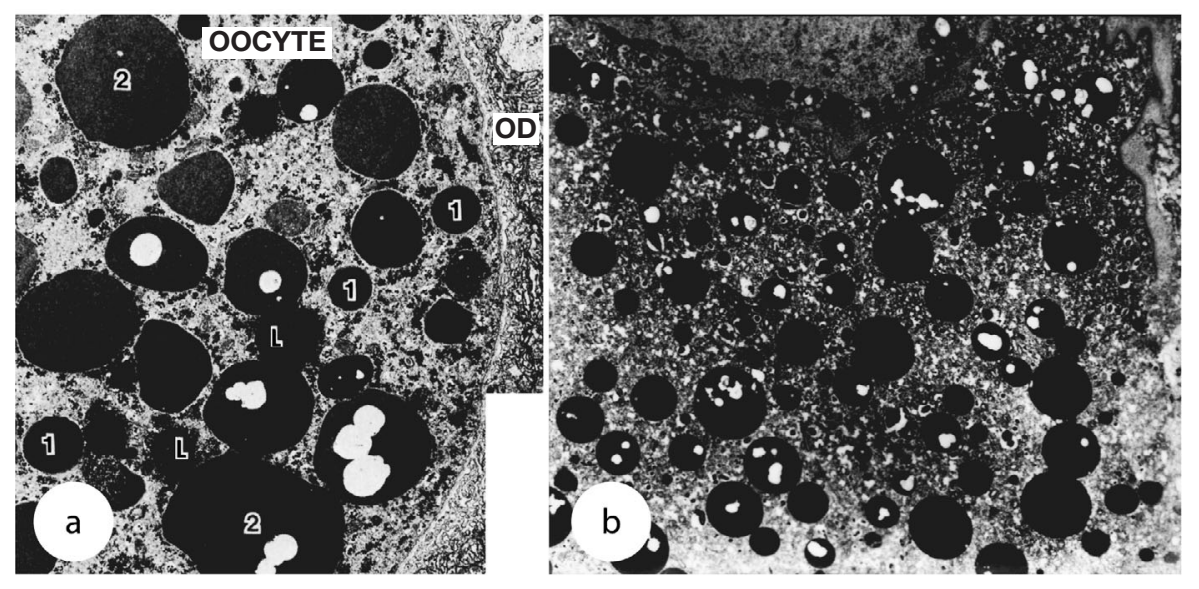

Fig. 5. Transmission electron micrographs. (a) Labidocera aestiva from subtropical south Florida waters showing poration of mature oocytes that have passed through the oviduct (OD); lipid droplet (L), type 1 yolk sphere (1) and type 2 bodies (2) (magnification 3200×). With permission from Blades-Eckelbarger \& Youngbluth (1984). (b) Temora stylifera from Bay of Naples showing large number of yolk spheres filled with lipovitellin (magnification $1800 \times)$. With per-mission from Laabir et al. (2001) 


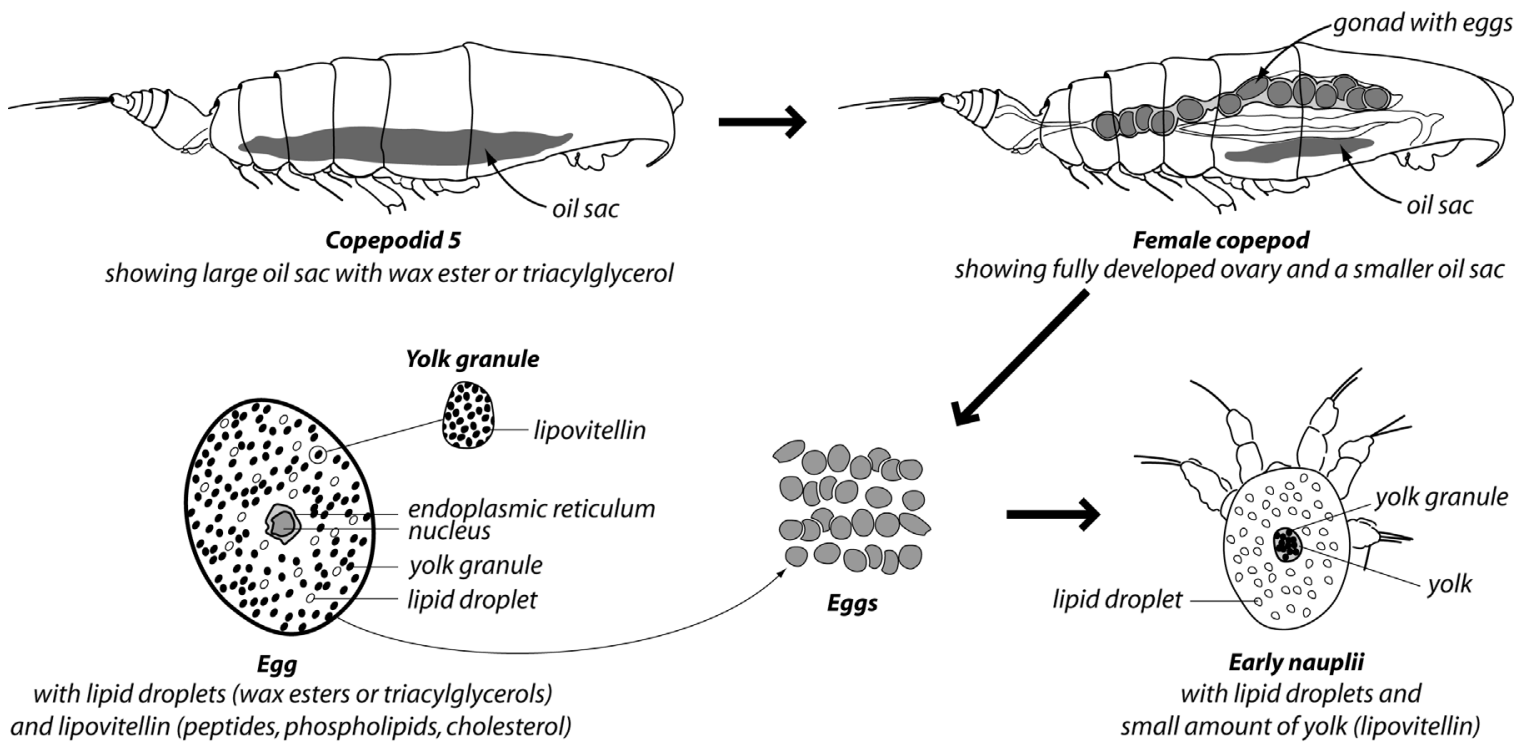

Fig. 6. Formation of eggs in oil sac containing copepod with lipid droplets (wax esters or triacylglycerols) and lipovitellin associated with yolk granules; note reduction of oil sac size from C5 to female as lipid in oil sac is utilized to provide lipid for assembly of lipid droplets and lipovitellin. Early nauplii utilize lipid droplets and lipovitellin for energy and to form membranes and organelles

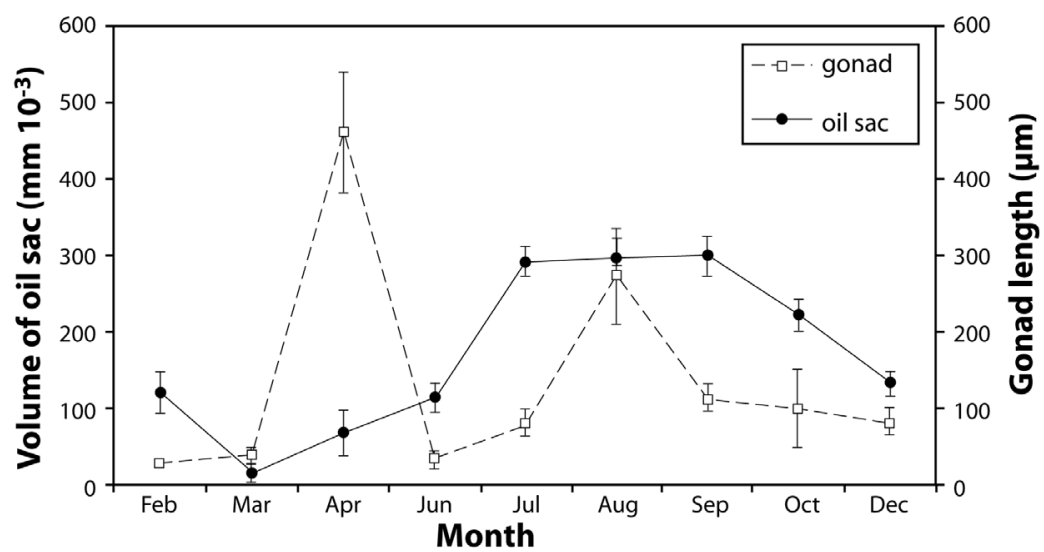

Fig. 7. Calanus hyperboreus (C5) off northern Norway. Seasonal changes in oil sac volume and gonad length. Modified from Pasternak et al. (2001)

E. media and Euphausia crystallorophias, while triacylglycerols in lipid droplets are the important neutral lipid class of the eggs of $C$. helgolandicus, C. pacificus and Euphausia superba (Table 3) (Lee et al. 1972, 1974, Lee \& Hirota 1973, Herring \& Morris 1975, Gatten et al. 1980, Conover 1988, Kattner \& Hagen 1998, Hagen \& Auel 2001). The importance of egg lipid droplets is likely related to the amount of energy required by the early developmental stages. Eggs of the shrimp species Penaeus setiferus, Crangon crangon and C. allemanni lack or have only trace amounts of storage lipids (Kattner et al. 1994b, Lee \& Broudy

ing lipid-rich eggs, which hatch into nauplii that have lipid droplets and yolk granules with lipovitellin. Female northern krill Meganyctiphanes norvegica undergoing oogensis and vitellogenesis were found to accumulate large amounts of phospholipids synthesized in the digestive gland and fat body (Cuzin-Roudy \& Buchholz 1999, Cuzin-Roudy et al. 1999, Albessard et al. 2001). The eggs of this species are rich in phospholipids containing $75 \%$ phospholipids and 9\% triacylglycerols, and we suggest that the egg phospholipids are associated with egg lipovitellin.

Wax esters in the form of lipid droplets are the major storage lipid of eggs of Acanthephyra pelagica, Calanus hyperboreus, Euchaeta japonica, E. marina, unpubl. data). Their eggs hatch soon after release, and the naupliar stages immediately start feeding. In contrast, the eggs of the copepods Euchaeta japonica and C. plumchrus are full of lipid droplets, and feeding does not begin until the late naupliar stages, i.e. after 20 to 30 d (Lee et al. 1974, Saito \& Tsuda 2000).

Based on the time of reproduction and the amount of storage lipid accumulated for reproduction, zooplankton can be separated into 3 groups (Fig. 8). Group 1 comprises zooplankton with large lipid stores, which are able to reproduce during a period when food is either not available or at very low concentrations. This group consists of copepods and euphausiids in polar and westerlies biomes including Calanus hyperboreus, 
Table 3. Total lipids (mass per egg or ind.)and lipid class compositions of eggs and females of copepods, euphausiids, decapods and mysids (n: number of eggs per female)

\begin{tabular}{|c|c|c|c|c|c|c|c|}
\hline & $\begin{array}{l}\text { Lipid } \\
\text { mass }(\mu g)\end{array}$ & $\begin{array}{l}\text { Lipid } \\
(\% \mathrm{DM})\end{array}$ & $\begin{array}{l}\text { WE } \\
(\% \mathrm{TL})\end{array}$ & $\begin{array}{l}\text { TAG } \\
(\% \mathrm{TL})\end{array}$ & $\begin{array}{c}\mathrm{PL} \\
(\% \mathrm{TL})\end{array}$ & Location & Source \\
\hline \multicolumn{8}{|l|}{ Copepoda } \\
\hline C. carinatus eggs $(\mathrm{n}=1400)$ & 0.6 & 75 & - & - & - & Benguela Current & Borchers \& Hutchings (1986) \\
\hline C. carinatus $\mathrm{C} 5$ & 131 & 71 & - & - & - & & Borchers \& Hutchings (1986) \\
\hline C. finmarchicus eggs $(\mathrm{n}=600)$ & 0.07 & 15 & 17 & 15 & 69 & Gulf of St. Lawrence & Ohman \& Runge (1994) \\
\hline C. finmarchicus female & 105 & 31 & 71 & 2 & 25 & & Diel \& Tande (1992) \\
\hline E. japonica eggs $(\mathrm{n}=14)$ & 40 & 64 & 58 & 19 & 21 & Strait of Georgia, & Lee et al. (1974) \\
\hline E. japonica female & 600 & 52 & 60 & 17 & 20 & Canada & Lee et al. (1974) \\
\hline$N$. tonsus eggs $(\mathrm{n}=285)$ & 0.14 & 66 & 11 & 6 & 66 & New Zealand & Ohman et al. (1989) \\
\hline N. tonsus female & 150 & 30 & 88 & 1 & 9 & & \\
\hline$P$. antarctica eggs $(\mathrm{n}=60)$ & 6.2 & 36 & - & - & - & Antarctic & Alonzo et al. $(2000 a, b)$ \\
\hline$P$. antarctica female & 2800 & 47 & 94 & 3 & 3 & Antarctic & Alonzo et al. $(2000 a, b)$ \\
\hline \multicolumn{8}{|l|}{ Euphausiacea } \\
\hline $\begin{array}{l}\text { E. crystallorophias eggs } \\
(\mathrm{n}=135)\end{array}$ & 23 & 51 & 62 & - & - & Weddell Sea & Kattner \& Hagen (1998) \\
\hline E. crystallorophias female & 28000 & 50 & 56 & 6 & 34 & & $\begin{array}{l}\text { Hagen (1988), Hagen \& } \\
\text { Auel (2001) }\end{array}$ \\
\hline E. superba eggs ( $\mathrm{n}=14500)$ & 9.4 & 35 & - & 31 & 29 & South Georgia & Clarke \& Morris (1983) \\
\hline E. superba female & 98000 & 35 & 1 & 29 & 29 & & Clarke $(1980,1983,1984)$ \\
\hline Decapoda & & & & & & & Clarke (1983) \\
\hline A. pelagica eggs $(n=132)$ & 390 & 49 & 11 & 47 & 23 & North Sea & $\begin{array}{l}\text { Herring (1973), Herring \& } \\
\text { Morris (1975) }\end{array}$ \\
\hline A. pelagica female & 115000 & 33 & 7 & 73 & 16 & & $\begin{array}{l}\text { Herring (1973), Herring \& } \\
\text { Morris (1975) }\end{array}$ \\
\hline \multicolumn{8}{|l|}{ Mysidacea } \\
\hline $\begin{array}{l}\text { Gnathophausia sp. eggs } \\
\text { (n = 220) }\end{array}$ & 2700 & 82 & 11 & 71 & 6 & North Pacific & Lee (unpubl. data) \\
\hline Gnathophausia sp. female & 2200000 & 42 & 12 & 69 & 16 & & $\begin{array}{l}\text { Lee et al. (1971a), Lee } \\
\text { (unpubl. data) }\end{array}$ \\
\hline
\end{tabular}

C. cristatus, Neocalanus plumchrus, Euchaeta japonica, E. norvegica and Thysanoessa macrura. These zooplankters reproduce in winter and early spring before phytoplankton has appeared, and they utilize lipid accumulated from the previous spring/summer feeding period (Fig. 9a) (Hagen 1988, Conover \& Siferd 1993, Kattner \& Hagen 1998, Falk-Petersen et al. 2000, Hagen \& Auel 2001, Ringuette et al. 2002). In the Antarctic euphausiid Thysanoessa macrura, lipids decreased from 40 to $9 \% \mathrm{DM}$ (Sep to Nov) after reproduction was completed. The lipid utilized was not replaced until the phytoplankton bloom later in the year (Hagen et al. 1996, Hagen \& Kattner 1998). Similarly, female $C$. hyperboreus had a winter/early spring spawn during which lipids decreased from 50 to $25 \%$ DM (Conover \& Corner 1968). The importance of storage lipids for late winter reproduction in C. hyperboreus is illustrated in Fig. 7, where there was a decrease in the oil sac volume followed by an increase in gonad size (Pasternak et al. 2001). After reproduction was completed and a summer phytoplankton bloom had begun, the oil sac increased in size.
Eggs of group 1 zooplankton are characterized by large yolks, many lipid droplets, lower density than seawater (except Euchaeta) and non-feeding by early larval stages (Nakai 1969, Conover 1988, Hagen \& Auel 2001, Auel et al. 2003). Since Calanus hyperboreus, Neocalanus cristatus, $N$. plumchrus and $N$. flemingeri discharge their eggs in deep waters, the early nauplii may ascend more quickly to surface waters due to the positive buoyancy as a result of many lipid droplets. Both $E u-$ chaeta japonica and E. norvegica have major spawns in winter, when little food is available (Hopkins 1977, Båmstedt 1979, Hopkins et al. 1982). The egg yolk allows development without feeding through all naupliar stages and the first copepodite stage (Fig. 9) (Lee et al. 1974). E. norvegica females decreased from 1800 to $600 \mu \mathrm{g}$ lipid/individual after spawning with each egg sac containing $500 \mu \mathrm{g}$ lipid, while E. japonica females used most of their lipids for reproduction, since an egg sac and a gravid female had 560 and $600 \mu \mathrm{g}$ lipid, respectively (Table 3) (Båmstedt \& Matthews 1975). C. glacialis seems to have an intermediate position between groups 1 and 2, since it appears to have enough lipid to carry out 


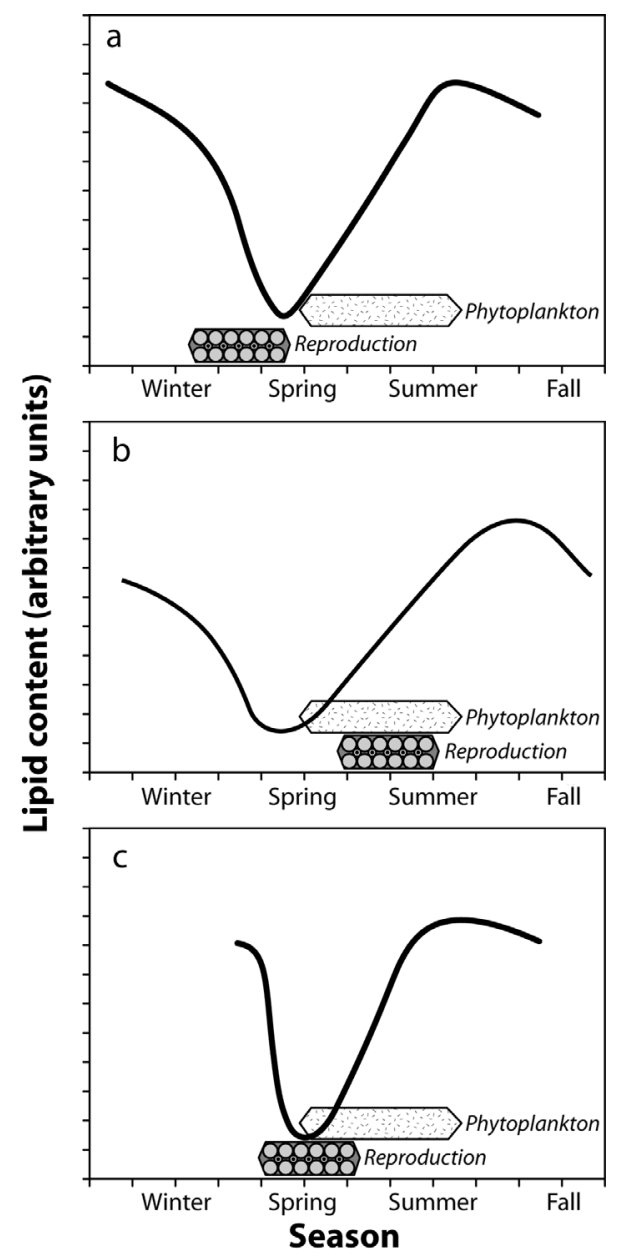

Fig. 8. Changes in lipid content during reproduction of different zooplankton groups. (a) Group 1 zooplankton with reproduction fueled by accumulated lipid; (b) Group 2 zooplankton with reproduction fueled by diet due to insufficient lipid stores; (c) Group 3 zooplankton with reproduction possible before and during phytoplankton bloom. Modified from FalkPetersen et al. (2000)

reproduction without additional food, although egg production rates increased up to 6 times when food was offered (Hirche \& Kattner 1993).

In contrast, group 2 females need to feed for successful reproduction because they have insufficient amounts of storage lipids. Species including Calanus australis, C. finmarchicus, Calanoides carinatus, and Euphausia superba utilize stored lipids during winter but must feed on the spring/summer phytoplankton blooms to produce large amounts of eggs (Fig. 8b) (Hirche \& Kattner 1993, Hagen et al. 1996, FalkPetersen et al. 2000, Hagen \& Auel 2001, Quetin \& Ross 2001, Niehoff 2004). C. finmarchicus egg production has been shown to depend on the concentration of phytoplankton with 600 eggs per female produced under bloom conditions but much lower egg produc-

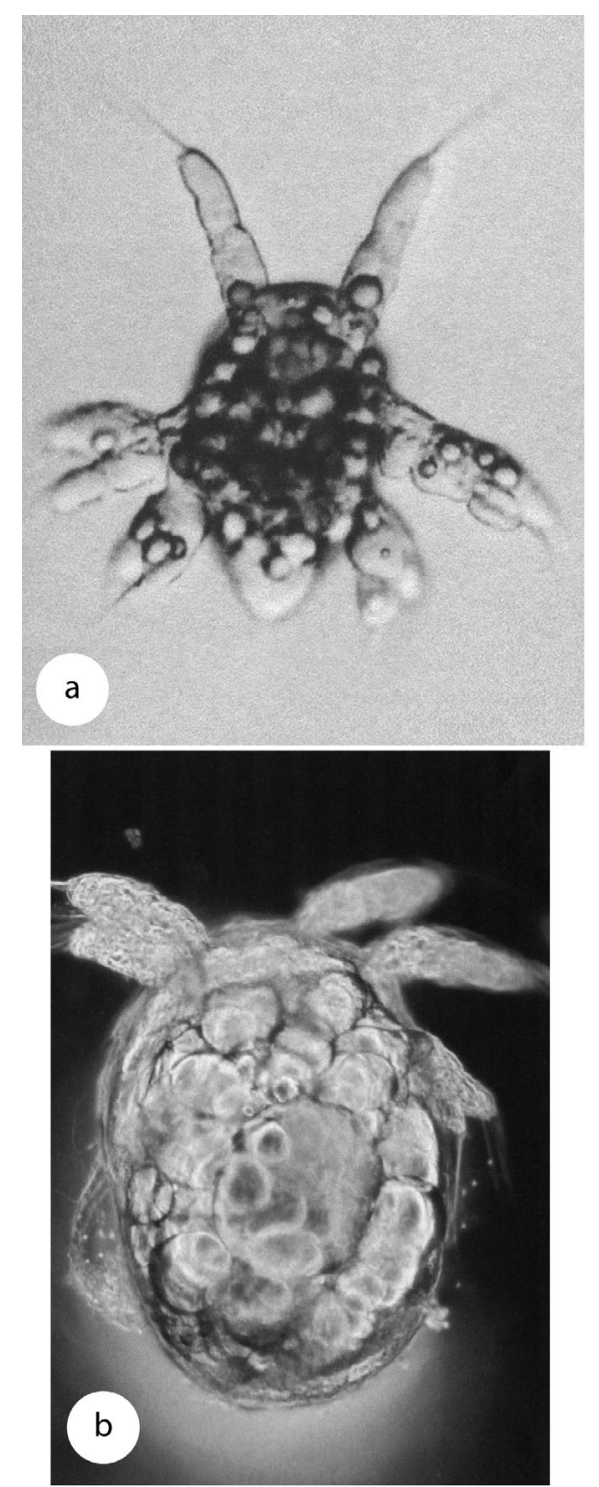

Fig. 9. Light photomicrograph of nauplii. (a) Neocalanus flemingeri with large number of lipid droplets (magnification $28 x_{i}$ with permission from Saito \& Tsuda 2000); (b) Euchaeta japonica with yolk still present in center of nauplius (magnification $70 \times 1$

tion under low food concentrations (Diel \& Tande 1992, Nielsen \& Hansen 1995). A female with $105 \mu \mathrm{g}$ of lipid would need to transfer $42 \mu \mathrm{g}$ of this lipid into 600 eggs (Table 3). Early in the season a few gravid C. finmarchicus females enter surface waters before the phytoplankton bloom, and these early females use lipid stores for egg production (Richardson et al. 1999). However, most females require phytoplankton food for successful reproduction. E. superba has 136 and $98 \mathrm{mg}$ lipid in eggs and females, respectively (Table 3 ). Thus, E. superba reproduction takes place during summer, 
when phytoplankton concentrations are high enough to provide sufficient energy for successful reproduction.

Group 3 zooplankton (Fig. 8c) are species in which some of the females have sufficient lipid for reproduction while other females require additional food to reproduce successfully. Examples of group 3 include Euphausia crystallorophias and Neocalanus tonsus. Female $N$. tonsus in deep water in winter $(145 \mu \mathrm{g}$ lipid/female) spawned in the absence of food, but spring females (47 $\mu \mathrm{g}$ lipid/female) in surface waters required food before spawning (Ohman 1987). Based on the amount of lipid per female it was calculated that deep-living females would have a predicted reproductive potential of 285 eggs, as compared to females at the surface in spring with only 4 eggs. In E. crystallorophias first spawning takes place before the phytoplankton bloom but the final spawning overlaps with the beginning of the phytoplankton bloom (Kattner \& Hagen 1998). E. crystallorophias collected before the bloom had 3.1 and $28 \mathrm{mg}$ lipid in eggs and female, respectively, so these females had sufficient lipid stores to supply lipids for the eggs (Table 3 ).

Most work on the utilization of stored lipids for spawning has been done on zooplankton from polar or westerlies biomes since these animals often build up large lipid stores before reproduction (Båmstedt \& Matthews 1975, Herring \& Morris 1975, Corkett \& McLaren 1978, Båmstedt 1979, Clarke 1980, Gatten al. 1980, Falk-Petersen et al. 1981, 2000, Sargent \& Henderson 1986, Hirche 1989, Nicol et al. 1995). Small lipid sacs and lipid droplets in the ovaries during oogenesis have been observed in several tropical and subtropical zooplankters, including Euchaeta marina, Pleuromamma xiphias, Anomalocera patersoni and Labidocera aestiva (Figs. 4c \& 5a) (Blades-Eckelbarger 1991, Ianora \& Santella 1991). Such studies suggest that storage lipids can also play an important role in tropical and subtropical zooplankton reproduction.

\section{Ontogeny}

Some zooplankton species produce larvae which must begin feeding soon after hatching (planktotrophic), but others have non-feeding larval stages (lecithotrophic) which rely on yolk lipid stores. In addition, coastal and estuarine benthic invertebrates often produce planktonic larvae which depend on lipid droplets and lipovitellin in their yolks. For example, the non-feeding cyprid larvae of the barnacle Balanus balanoides contain numerous large triacylglycerol droplets, which are gradually consumed until the larvae have found a suitable settlement substrate (Holland \& Walker 1975, Lucas et al. 1979). Oyster larvae
(Ostrea edulis) rely on oil droplets, which can have up to $12 \% \mathrm{DM}$ as triacylglycerols (Holland \& Spencer 1973, Holland \& Hannant 1974).

Euphausiids have a long and complex larval sequence with 2 naupliar, 1 metanaupliar, 3 calyptopis and 6 furcilia stages before metamorphosis into juveniles. Euphausia superba eggs descend to great depth below $1000 \mathrm{~m}$ (Marr 1962), and the nauplii and metanauplii must utilize lipids as they migrate to the surface. Krill start feeding with the first calyptopis stage, 20 to $40 \mathrm{~d}$ after spawning, so that development from egg to this stage relies on stored lipids. Freshly spawned embryos, gastrulae and limb bud stages of E. superba contained 9.4, 7.7 and $5.9 \mu \mathrm{g}$ of lipid per individual, respectively, showing lipid utilization by the early larval stages of this Antarctic euphausiid (Clarke 1984, Amsler \& George 1985). Development of the non-feeding stages from egg to calyptopis, which takes 20 to $40 \mathrm{~d}$ in E. superba, E. crystallorophias and Thysanoessa longicaudata, must rely on stored lipids (Fevolden 1980, Clarke \& Morris 1983, Hagen 1999). In E. crystallorophias the amount of wax esters increases from larvae to adults, as shown in Fig. 10. The role of phosphatidylcholine for energy storage in E. superba was discussed above.

Most of the triacylglycerols found in eggs may have been converted from phosphatidylcholine in the storage tissues of the female. The calyptopis and furcilia stages feed in surface waters on the summer phytoplankton bloom, and immature stages, emerging from the furcilia, can accumulate large lipid stores by the end of summer (Kattner \& Hagen 1998). However, the furciliae have only a relatively short period in summer to accumulate enough storage lipids if they are to survive as furciliae over winter. The lipids of furcilia III larvae of E. superba were $15 \%$ DM (early autumn col-

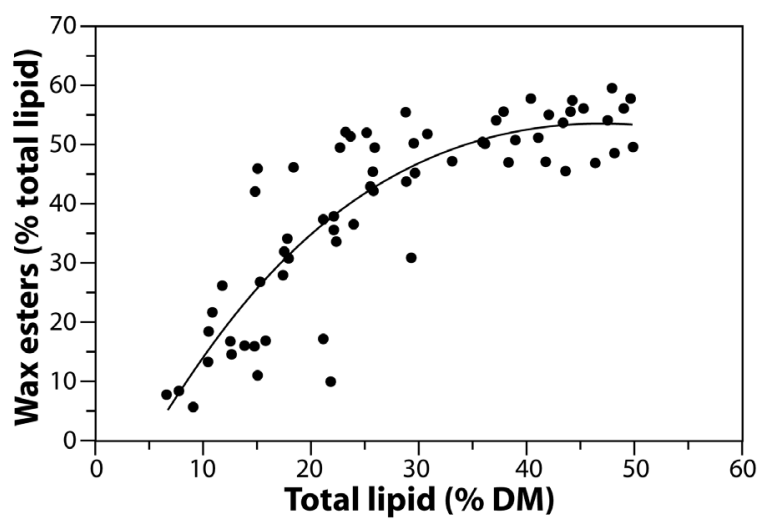

Fig. 10. Antarctic euphausiid Euphausia crystallorophias. Increases in wax esters levels (\%total lipid) and total lipid (\%DM) from larvae to adults. With permission from Kattner \& Hagen (1998) 
lection) with lipids consisting of 70 and $25 \%$ triacylglycerols and phospholipids, respectively (Meyer et al. 2002). Because of their relatively low lipid content, Hagen (1988) calculated that furcilia may last only 9 to $18 \mathrm{~d}$ without food. It has been suggested that, because of their relatively low lipid stores and their inability to withstand starvation, overwintering furciliae need to feed on ice algae to survive the winter (Daly 1990, Ross \& Quetin 1991, Hagen et al. 1996, 2001, Hagen 1999, Meyer et al. 2002).

Calanoid copepods undergo 12 molts between egg and adult, including 6 naupliar stages (N1 to N6) and, following metamorphosis, 6 copepodite stages, $\mathrm{C} 1$ to C5 plus C6, the adult male and female. The first feeding stages for the copepods Oithona davisae and Acartia spp. are N1 and N2, respectively (Landry 1983, Uchima \& Hirano 1986), while N3 is the first feeding stage of Pseudocalanus spp., Calanus hyperboreus, C. finmarchicus and C. marshallae (Conover 1967, Marshall \& Orr 1972, Corkett \& McLaren 1978, Peterson 1986, Williams et al. 1987). In the North Pacific copepod Euchaeta japonica and in the Antarctic copepod E. antarctica, there are sufficient resources in the egg yolk to allow development through 6 naupliar stages and the 1st copepodite stage before feeding is required (Lee et al. 1974, Yen unpubl. data).

The Arctic copepod Calanus hyperboreus reproduces continuously at depth in winter before the spring/summer phytoplankton bloom. The non-feeding stages, N1 \& N2, full of lipid droplets (B. Hansen pers. comm.), swim to the surface utilizing their storage lipids. The first feeding stages, N3 to N6, reach the surface with the onset of phytoplankton production (Conover \& Huntley 1991, Hirche \& Niehoff 1996). It is likely that naupliar and early copepodite stages, which first enter surface waters before phytoplankton is present, will die because they have depleted both lipid droplets and lipovitellin. Similarly, the eggs of the subarctic copepods Neocalanus cristatus, N. plumchrus and $N$. flemingeri are discharged in deep waters (500 to $2000 \mathrm{~m}$ ), and the nauplii migrate to the surface (Miller et al. 1984, Miller \& Nielsen 1988, Kobari \& Ikeda 1999). Photomicrographs of early naupliar stages show that these stages are full of lipid droplets (Fig. 10a), and as result of their lipid stores N. cristatus nauplii can develop to $\mathrm{C} 1$ without feeding (Saito \& Tsuda 2000). In contrast, photomicrographs of early naupliar stages of Calanus finmarchicus and C. pacificus indicate a relatively small number of lipid droplets, and thus these species must begin feeding by N3 (Hygum et al. 2000a, Lee unpubl. data). Fernandez (1979) found that N3 and N4 of C. pacificus could withstand starvation for only 4 to $6 \mathrm{~d}$.

Yolk lipid is utilized while copepods are in their naupliar and early copepodite stages. Lipid does not accu- mulate during this part of the life history even during extensive feeding. Håkanson (1984) noted that Calanus pacificus nauplii did not accumulate storage lipids even in the presence of excess phytoplankton. Similarly, the first 2 copepodite stages did not increase their very low wax ester content when fed higher food concentrations. Pseudocalanus minutus early copepodite stages lacked a visible oil sac, while late copepodite stages showed a distinct oil sac (Corkett \& McLaren 1969, Klein Breteler \& Gonzalez 1988).

High-latitude copepods have low levels of wax esters and triacylglycerols in the first 2 copepodite stages with a gradual increase of these lipids as development proceeds to later copepodite stages (C3 to C5) (Lee et al. 1972, 1974, Håkanson 1984, Kattner \& Krause 1987, Hygum et al. 2000b). Fig. 11a shows the accumulation of wax esters in Calanus finmarchicus C3 while feeding on a diatom bloom (Hygum et al. 2000c). The study showing increased accumulation of wax esters and triacylglycerols as C. finmarchicus developed from C3 to C5 stages was followed by Hygum et al. (2000c) during a spring/summer bloom near Tromsø, northern Norway (Fig. 11b). In mesocosms with different phytoplankton concentrations $(100,200$ and $688 \mu \mathrm{g}$ phytoplankton carbon $\mathrm{l}^{-1}$ ) there were corresponding increases in $C$. finmarchicus lipids as these copepods developed from C3 to C5 (Fig. 12) (Hygum et al. 2000c, Marker et al. 2003). Phytoplankton concentrations of 100, 300 and $900 \mu \mathrm{g}$ carbon $\mathrm{l}^{-1}$ fed to C. pacificus (C4 to C5) corresponded to wax ester contents of 1, 3.2 and $5.5 \mu \mathrm{g}$ per copepodid, respectively (Fig. 13).

An exception to the gradual accumulation of lipid in later copepodite stages is described for the Antarctic copepod Paralabidocera antarctica. It spends much of its life in the sea ice and is an example of copepods with nauplii that accumulate storage lipid. The early naupliar stages of this species enter the sea ice in early autumn, feed on ice algae, build up large stores of triacylglycerols and spend the winter as lipid-rich N4 in the ice (Swadling et al. 2000). In addition, Gannefors et al. (2005) found that the Arctic pteropod Limacina helicina overwinters as triacylglycerol-rich veligers.

\section{Coping with food scarcity}

The utilization of storage lipids allows zooplankton to survive periods of low food supply. Table 4 gives examples of zooplankton species from 2 groups separated by their differences with respect to lipid accumulation and the ability to withstand starvation. Species of group 1 have little or no storage lipid and can withstand only short periods of starvation, while species of group 2 accumulate large lipid stores to survive long starvation periods. 

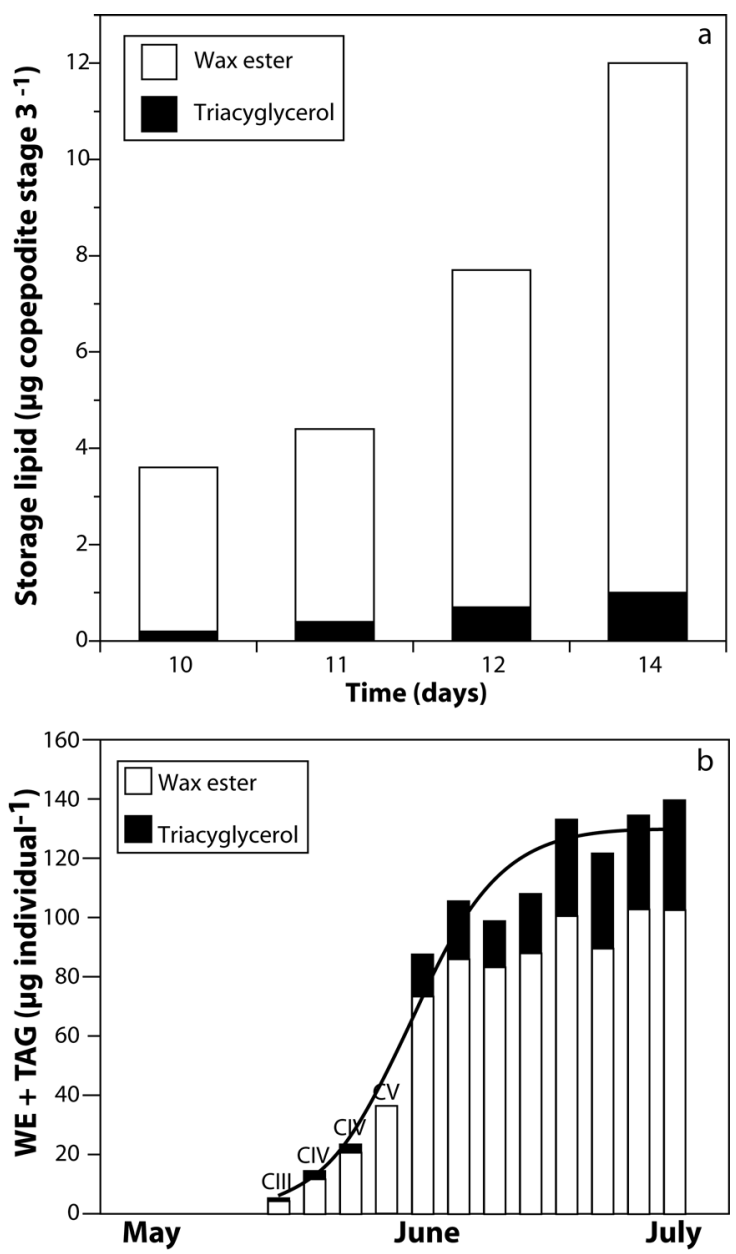

Fig. 11. Calanus finmarchicus. (a) Increases in wax ester and triacylglycerol levels of C3 (reared from C1) fed mainly on diatoms in Norwegian fjord mesocosm; modified from Hygum et al. (2000c). (b) Accumulation of wax esters and triacylglycerols ( $\mu \mathrm{g} /$ copepodite) by C3-C5 during summer (Tromsø, Norway). Unmarked bars are C5 stages. With permission from Marker et al. (2003)

Lipid-poor species include some inshore and estuarine copepods, epipelagic chaetognaths, cnidarians, ctenophores and tunicates. They grow rapidly during high food periods, but excess food is not converted into large lipid stores. Many of these copepods (Acartia spp., Labidocera acuta, L. aestiva, Pontella mediterranea, Tortanus forcipatus, Anomalocera patersoni) produce resting eggs during low food periods (Fleminger 1957, Zillioux \& Gonzalez 1972, Uye et al. 1979, Grice \& Marcus 1981, Heinle 1981, Matsuo \& Marumo 1982, Miller 1983, Uye 1985, Sullivan \& McManus 1986, Marcus 1989, Marcus \& Fuller 1989, Lindley 1990, Ianora \& Santella 1991). Low food concentrations are generally available year round to zooplankton in tropical or subtropical waters. Zooplankton from these warm-water areas is characterized by low amounts of

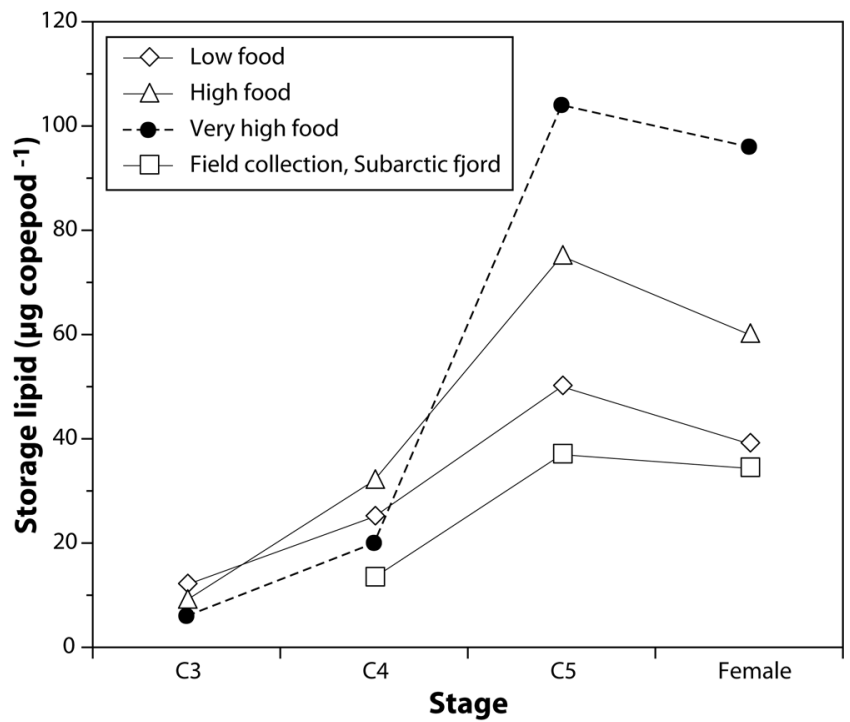

Fig. 12. Calanus finmarchicus from field and mesocosms located in Bergen, Norway. Changes in wax ester content from C3 to female. The mesocosms contained different phytoplankton concentrations, primarily diatoms, but dinoflagellates and ciliates were also present. Low, high and very high food concentrations comprised 100, 200 and $688 \mu \mathrm{g}$ phytoplankton $\mathrm{Cl}^{-1}$, respectively (Hygum et al. 2000c, Marker et al. 2003). Field-collected sample came from a subarctic Norwegian fjord (Scott et al. 2000)

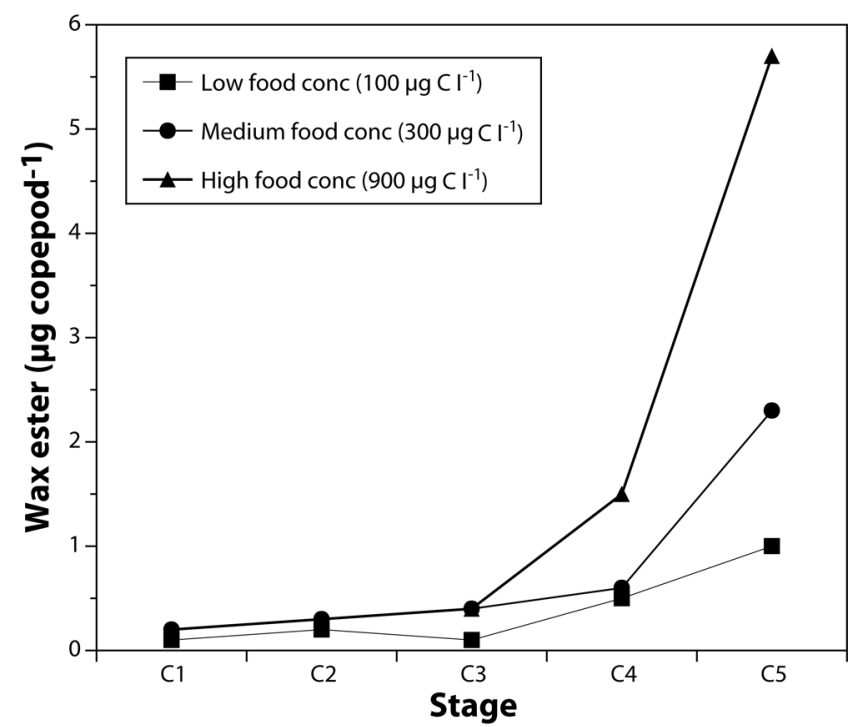

Fig. 13. Calanus pacificus. Changes in wax ester levels in C1-C5 fed on different concentrations of diatom Thalassiosira weissflogii. With permission from Håkanson (1984)

storage lipids and generally cannot withstand more than a few days of starvation (Reeve et al. 1970, Nival et al. 1974, Cosper \& Reeve 1975, Uye 1981, Gardner \& Paffenhöfer 1982, Feigenbaum \& Maris 1984, Feigenbaum 1991). 
Table 4. Total lipid data in relation to starvation tolerance of lipid-poor (group 1) and lipid-rich zooplankton species (group 2)

\begin{tabular}{|c|c|c|c|c|c|}
\hline & $\begin{array}{l}\text { Lipid mass } \\
\left(\mu \mathrm{g} \text { ind } .^{-1}\right)\end{array}$ & $\begin{array}{l}\text { Lipid } \\
(\% \mathrm{DM})\end{array}$ & $\begin{array}{l}\text { Starvation } \\
\quad \text { (d) }\end{array}$ & Location & Source \\
\hline \multicolumn{6}{|l|}{ Group 1} \\
\hline \multicolumn{6}{|l|}{ Copepoda } \\
\hline A. clausi & 1.4 & 3 & $3-6$ & N Atlantic/N Pacific & $\begin{array}{l}\text { Mayzaud (1976), Harris et al. (1977), } \\
\text { Kayama \& Mankura (1980), Uye (1981) }\end{array}$ \\
\hline A. tonsa & 2 & $16-19$ & $6-10$ & Inshore \& estuarine & $\begin{array}{l}\text { Lee \& Hirota (1973), Dagg (1977), Houde } \\
\text { \& Roman (1987) }\end{array}$ \\
\hline C. typicus & 7.8 & 13 & $3-6$ & Mediterranean estuaries & $\begin{array}{l}\text { Dagg (1977), Harris et al. (1977), Nival } \\
\text { et al. (1990) }\end{array}$ \\
\hline E. pileatus & - & - & 8 & NW Atlantic shelves & Gardner \& Paffenhöfer (1982) \\
\hline L. trispinosa & 30 & 14 & $2-3$ & California Current & Lee \& Hirota (1973), Lee (unpubl. data) \\
\hline T. stylifera & - & - & 27 & Mediterranean Sea & Nival et al. (1990) \\
\hline \multicolumn{6}{|l|}{ Ctenophora } \\
\hline Mnemiopsis leidyi & - & 4 & 5 & Tropical Caribbean Sea & $\begin{array}{l}\text { Kremer \& Reeve (1989), Lee (unpubl. } \\
\text { data) }\end{array}$ \\
\hline Pleurobrachia pileus & IS 300 & $2-9$ & $2-14$ & N Pacific & Lee (1974a), Hoeger (1983) \\
\hline \multicolumn{6}{|l|}{ Chaetognatha } \\
\hline Sagitta hispida & 100 & 4 & 7 & Caribbean Atlantic & Reeve et al. (1970), Lee (unpubl. data) \\
\hline \multicolumn{6}{|l|}{ Group 2} \\
\hline \multicolumn{6}{|l|}{ Copepoda } \\
\hline C. australis & 31 & 17 & $>10$ & Benguela Current & Attwood \& Peterson (1989) \\
\hline C. carinatus & 131 & 70 & $12-21$ & Benguela Current & Borchers \& Hutchings (1986) \\
\hline C. finmarchicus & 220 & 50 & $>21$ & N Atlantic & Dagg (1977), Sargent \& Henderson (1986) \\
\hline C. glacialis & 400 & 56 & $>270$ & Boreal Arctic & $\begin{array}{l}\text { Lee (1975), Hirche (1989), Hirche \& } \\
\text { Kattner (1993) }\end{array}$ \\
\hline C. pacificus & 140 & 45 & $>21$ & N Pacific & $\begin{array}{l}\text { Lee \& Hirota (1973), Runge (1984), } \\
\text { Hassett \& Landry (1990) }\end{array}$ \\
\hline C. hyperboreus & 1700 & 74 & $>90$ & High Arctic & Conover (1964), Lee (1974b) \\
\hline C. plumchrus & 410 & 59 & $>50$ & N Pacific & Benson et al. (1972) \\
\hline E. norvegica & 1400 & 46 & $>90$ & N Atlantic & $\begin{array}{l}\text { Båmstedt \& Matthews (1975), Sargent \& } \\
\text { Henderson (1986) }\end{array}$ \\
\hline G. princeps & 760 & 28 & $>60$ & California Current & Lee \& Barnes (1975) \\
\hline P. minutus & 2.1 & 17 & $>14$ & NW, NE Atlantic shelves & $\begin{array}{l}\text { Corkett \& McLaren (1969), Dagg (1977), } \\
\text { Fraser et al. (1989), Båmstedt et al. (1990) }\end{array}$ \\
\hline \multicolumn{6}{|l|}{ Euphausiacea } \\
\hline E. superba & 98000 & 35 & $>211$ & Antarctic & Clarke $(1980,1984 a)$, Ikeda \& Dixon (1982) \\
\hline \multicolumn{6}{|l|}{ Pteropoda } \\
\hline Clione limacina & 4400 & 31 & $>90$ & N Pacific & Lee $(1974 a)$ \\
\hline Clione limacina & 12000 & 19 & 356 & Arctic, Svalbard & Böer et al. (2005) \\
\hline
\end{tabular}

Lipid-rich taxa, such as copepods, euphausiids, decapods and certain pteropods from polar and temperate regions, accumulate large lipid stores during periods of high food availability followed by long starvation periods. The starvation survival times given in Table 4 for these taxa may be underestimates since bacterial infections and other factors make long laboratory starvation studies difficult to carry out. Such studies were undertaken by Ikeda \& Dixon (1982) and Hirche (1989), where Euphausia superba and Calanus glacialis were starved for 211 and 270 d, respectively. Each year diapausing polar copepods have to cope with 270 or more days of starvation since they enter deep waters in summer and do not reenter surface waters until the following spring. The starvation survival times given in Table 4 are for adults or near adults, since the larval stages often cannot survive more than a few days without food (Fernandez 1979, Ikeda \& Dixon 1982, Ikeda 1984, Borchers \& Hutchings 1986). However, some species, e.g. Neocalanus cristatus and Euchaeta japonica, have larval forms with large lipid stores to withstand long starvation periods (Lee et al. 1974, Saito \& Tsuda 2000). 


\section{Diapause}

Lipid accumulation of many herbivorous copepods is closely linked to phytoplankton blooms. They feed extensively during blooms and accumulate large lipid stores. As a result of excess food these copepod species build up lipid stores and migrate to deep waters for diapause (Fig. 14, Table 5). Some species with insufficient storage lipids remain at the surface and overwinter with an omnivorous feeding strategy.

The best characterized of these copepods are species of the genera Calanus, Calanoides and Neocalanus from various ocean regions (Fig. 15). In polar regions, Calanus hyperboreus and Calanus glacialis exist in the Arctic and Calanoides acutus in the Antarctic. In boreal and temperate regions Calanus finmarchicus and Calanus helgolandicus occur in the North Atlantic, Calanoides carinatus in the South Atlantic/Northwest Indian and northwestern Arabian upwelling regions, Neocalanus plumchrus/N. cristatus in the North Pacific and N. tonsus

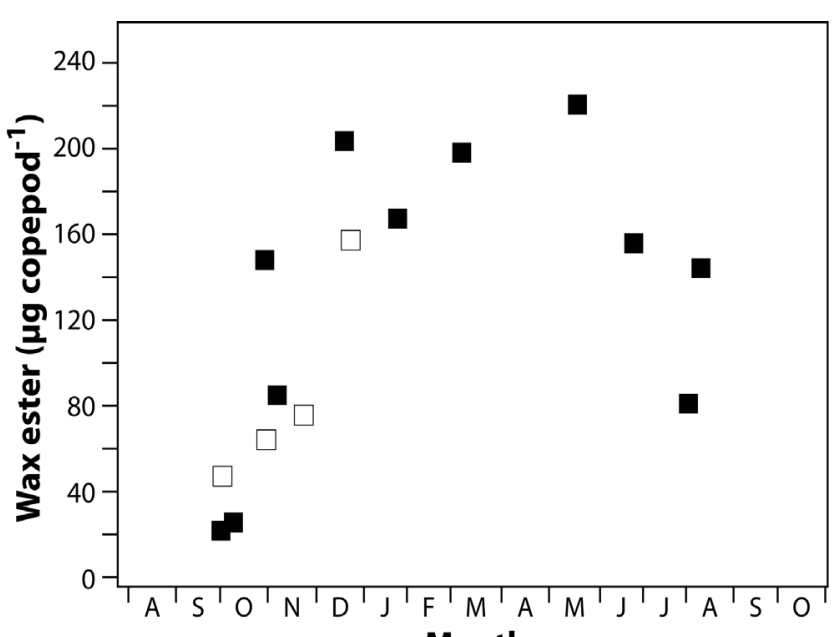

Fig. 14. Neocalanus tonsus (C5). Seasonal changes in wax ester levels ( $\mu \mathrm{g} / \mathrm{copepod})$. Animals collected $(\square)$ in surface waters $(0-105 \mathrm{~m}) ;(\boldsymbol{\square})$ in deep waters $(500-1000 \mathrm{~m})$. With permission from Ohman et al. (1989)

Table 5. Calanus spp., Calanoides spp. and Neocalanus spp. Total lipid, storage lipid classes and related data of copepods that undergo deep-water diapause in various biomes

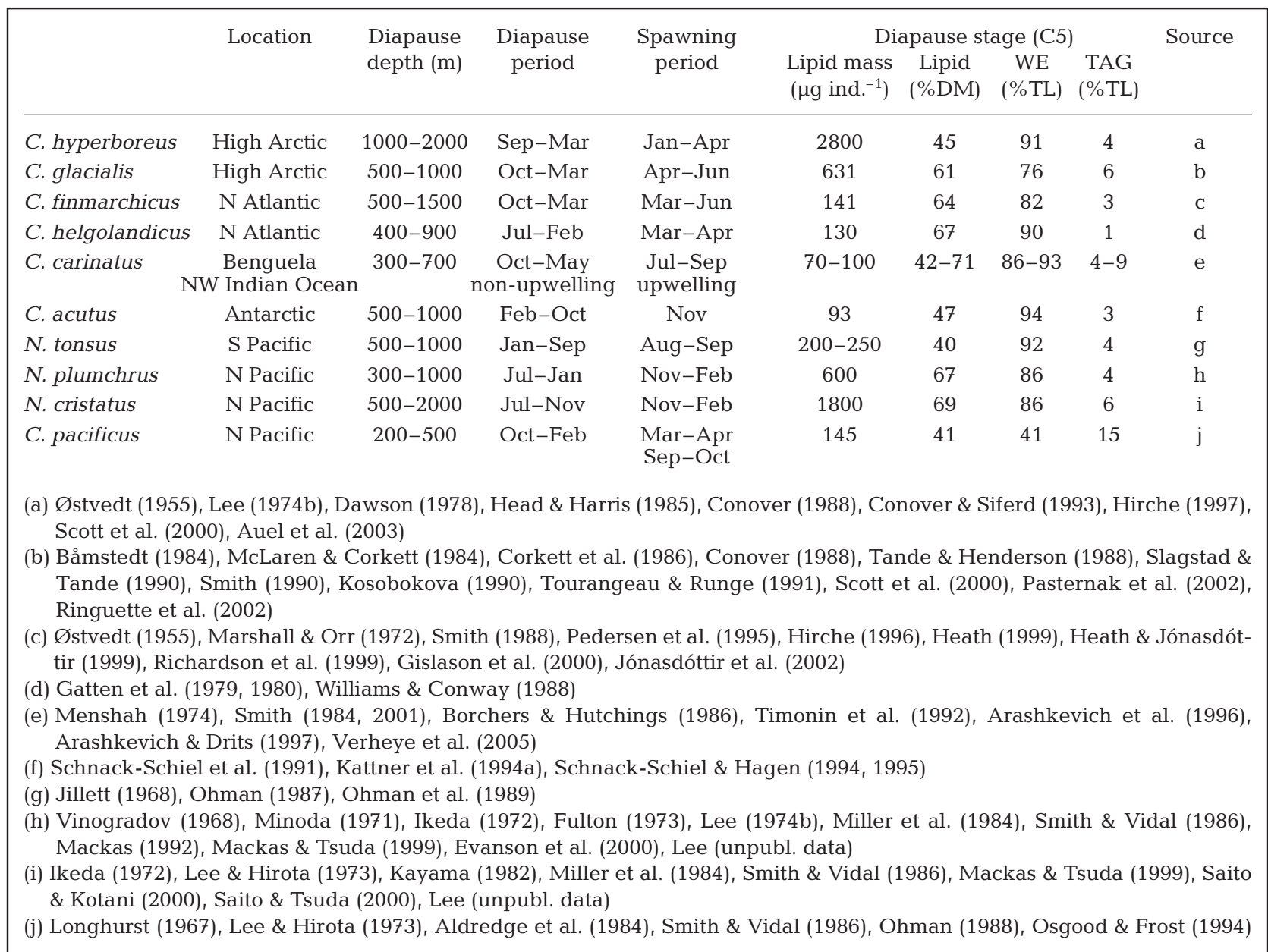




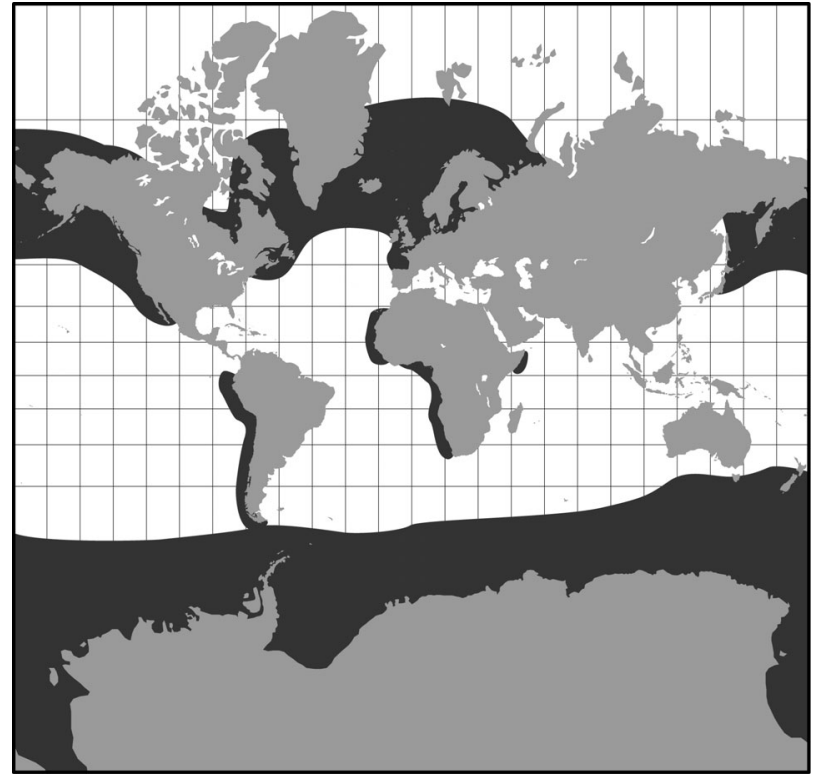

Fig. 15. Ocean regions (shaded in black), where various Calanidae (C5) undergo diapause after accumulation of large wax ester stores. The species include Calanoides carinatus (South Africa, Gulf of Aden), Calanus pacificus (California, USA), C. marshallae (Oregon, Washington, USA), C. chilensis, C. australis (South America), C. finmarchicus (north Atlantic), C. hyperboreus, C. glacialis (Arctic), Neocalanus cristatus, N. plumchrus (north Pacific), Calanoides acutus (Antarctic), $N$. tonsus (subantarctic)

in the subantarctic. In coastal waters Calanus pacificus is found in the North Pacific. Although storage lipid data are not available, it is likely that Calanus sinicus in the coastal China Sea builds up storage lipids since this species diapauses during summer and can withstand more than $30 \mathrm{~d}$ of starvation (Sun et al. 2002).

The presence of oil sacs filled with wax esters are a distinctive feature of diapausing copepods (Figs. 2 \& 3a) so that more than half of the dry mass can be lipid. The reason for the use of wax esters in deep diapausing copepods is perhaps due to the fact that the thermal expansion and compressibility of wax esters is higher than that of seawater (Yayanos et al. 1978). Visser \& Jónasdóttir (1999) suggested that a copepod, which is positively buoyant in warm surface waters, can become neutrally buoyant in cold deep water. As a result, even though the copepods are full of lipids, they should require minimal energy to maintain themselves in deep cold waters. Campbell \& Dower (2003) discussed the difficulty of maintaining neutral buoyancy by these lipid-rich zooplankton species. In addition to diapausing copepods, most deep-water zooplankters, independent of latitude, have high amounts of wax esters (Lee et al. 1971a, Lee \& Hirota 1973). The neutral buoyancy provided by wax esters in cold deep water may be advantageous to these deep-water zooplankton species.
The life cycle of high-latitude diapausing copepods has a strong linkage to the spring/summer phytoplankton blooms. Reproduction often occurs just before or during the phytoplankton bloom. At some point nauplii, after hatching, begin feeding on phytoplankton. They then undergo metamorphosis and exhibit highest lipid accumulation in C5 or adult (Figs. 11b \& 16, Table 5). Many species migrate into deep waters after the accumulation of large wax ester stores. This can even occur when phytoplankton is still available; hence, maximum lipid accumulation may provide a signal for C5 to descend to deep waters (Irigoien 2004). Much larger lipid deposits are present in deeperdwelling copepods as compared to those in upper layers (Båmstedt 1984) (Fig. 17a). Jónasdóttir (1999) found a linear relationship between the amount of storage lipid in Calanus finmarchicus and the depth of capture (Fig. 17b). Similarly, Pasternak et al. (2001) noted a much larger oil sac volume for deep-water $C$. finmarchicus C5 compared to the same stage in upper layers. A small percentage of $C$. finmarchicus developed into C5 late in the season. We hypothesize that these copepods do not receive the signal to descend because of insufficient lipid stores and thus spend the winter in surface waters. It seems likely that many of

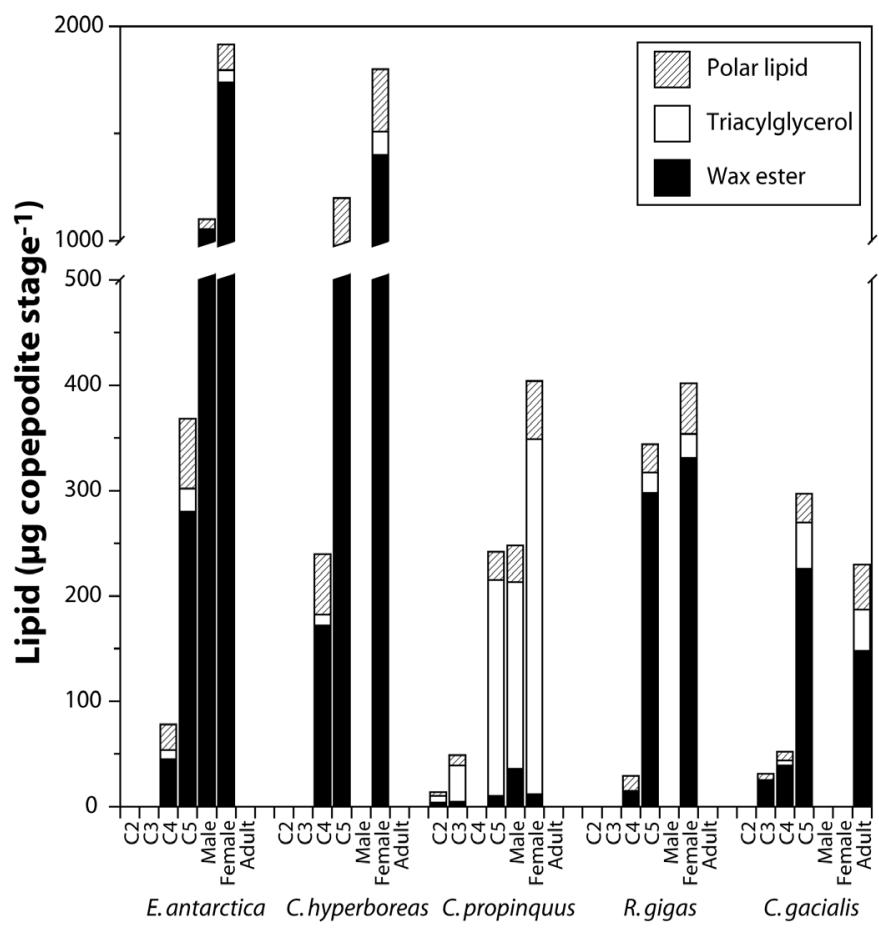

Fig. 16. Wax ester, triacylglycerol and polar lipid levels ( $\mu \mathrm{g}$ per copepodid) of various copepodite stages and adults of Antarctic (Euchaeta antarctica, Calanus propinquus, Rhincalanus gigas) and Arctic copepods (C. hyperboreus, C. glacialis). Data from Hagen (1988), Tande \& Henderson (1988), Kattner et al. (1994a), Scott et al. (2000) 

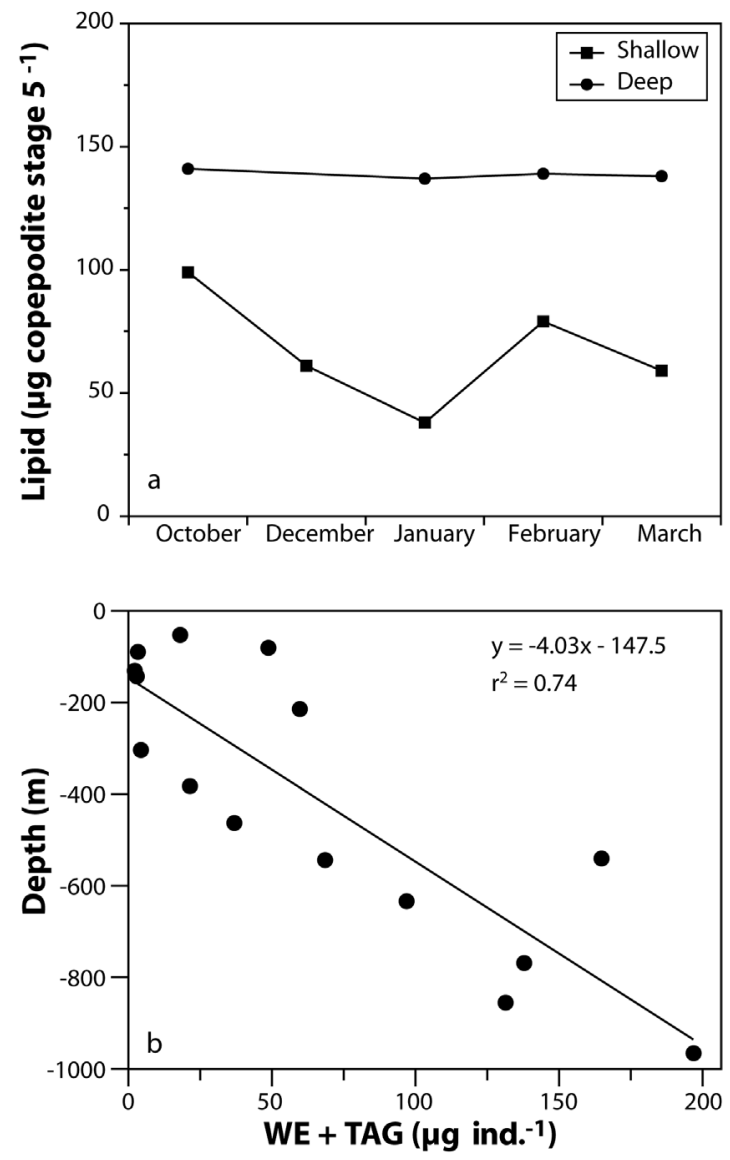

Fig. 17. Calanus finmarchicus (C5). (a) Lipid levels ( $\mu \mathrm{g}$ ind. ${ }^{-1}$ ) of specimens collected from October to March in shallower waters $(<400 \mathrm{~m})$ and deeper waters $(>400 \mathrm{~m})$. (b) Correlation of wax ester plus triacylglycerol level $(\mu \mathrm{g} / \mathrm{C} 5)$ with capture depth (specimens collected in January). Data from Jónasdóttir (1999)

these copepods will die due to poor resources for overwintering.

Another copepod, the North Pacific Neocalanus cristatus, reaches adulthood in deep water during winter, and its reproduction peak occurs in November. The hatched nauplii ascend to the surface utilizing lipid reserves. The late naupliar and early copepodite stages feed on the spring bloom. After extensive feeding, the summer $\mathrm{C} 5$ is full of wax esters and descends into deep waters from July through October, completing the life cycle (Miller et al. 1984). N. plumchrus C5 stages enter deep waters in July and remain in diapause from July to January, followed by deep-water reproduction in January and February, and ascend as nauplii to surface waters (Fulton 1973). Campbell et al. (2004) observed that $N$. plumchrus C5 stages, collected in the Strait of Georgia, use approx. 1/4 of their wax ester stores for overwintering prior to moulting. In both Neocalanus species C5 stages enter deep cold water, while phytoplankton concentrations in the surface waters are still high. A somewhat different situation occurs in the Arctic copepods Calanus hyberboreus and C. glacialis, since the spring/summer phytoplankton bloom is very short, and many of the copepodids do not develop into C5 during the 1st year. C3 and C4 stages usually have sufficient wax ester stores at the end of the phytoplankton bloom to descend into deep waters for winter diapause. These C3 and C4 stages develop into C5 during the following summer (Conover 1967, Båmstedt 1984, Corkett et al. 1986, Kosobokova 1990, Conover \& Huntley 1991, Hirche \& Kattner 1993). C. hyperboreus C5 specimens can accumulate up to $2800 \mu \mathrm{g}$ lipid per individual before descending to deep waters (Head \& Harris 1985).

\section{Wax esters vs. triacylglycerols}

In herbivorous copepods with large amounts of wax esters stored in oil sacs, triacylglycerols and wax esters are utilized and accumulated at very different rates. Triacylglycerol content is generally an order of magnitude lower than wax ester content (Fig. 18). The oil sacs in these copepods contain only wax esters (Benson et al. 1972), whereas triacylglycerols are stored in other body regions, likely in the form of lipid droplets (Sargent \& Henderson 1986).

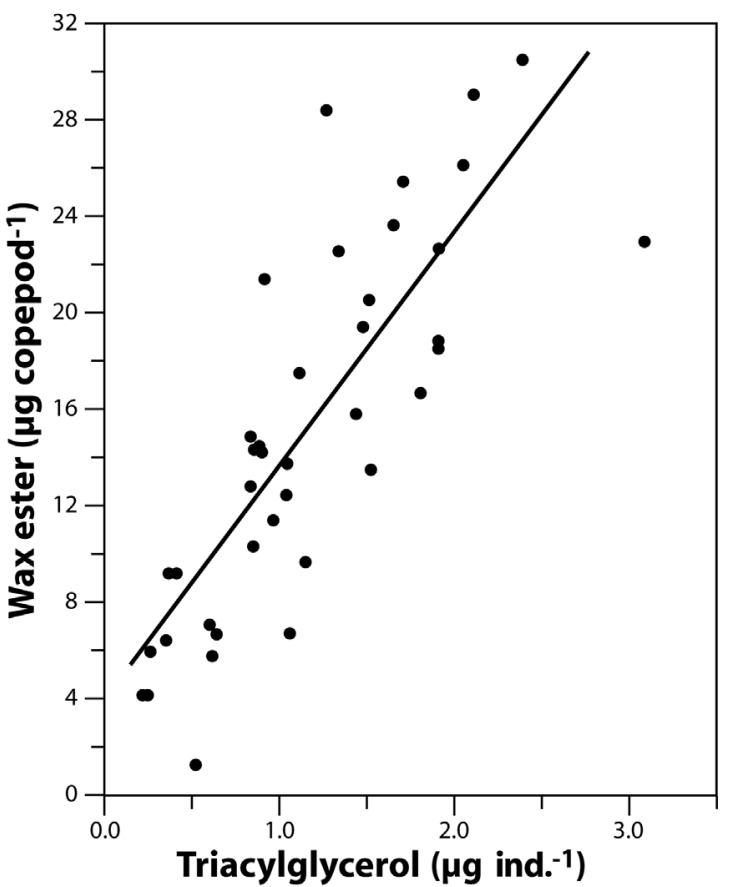

Fig. 18. Calanus pacificus (C5) from different stations in California Current. Mean wax ester vs. triacylglycerol levels $(\mu \mathrm{g} / \mathrm{C} 5)$. With permission from Håkanson (1987) 
A pathway can be described where copepods, provided with an excess of food, assemble storage lipids in 2 phases. The initial phase is the synthesis and storage of triacylglycerol droplets; the second phase is the synthesis and storage of wax esters in an oil sac (Miller et al. 1998). Starvation of wax-ester-rich copepods (Calanus pacificus, C. helgolandicus, Euchaeta japonica, Gaussia princeps) resulted in preferential utilization of triacylglycerols, followed by a slower rate of wax ester utilization (Lee et al. 1974, Lee \& Barnes 1975, Sargent et al. 1977, Håkanson 1984). Because triacylglycerols and wax esters are utilized at very different rates, 2 different lipases may be responsible for the catabolism of triacylglycerols and wax esters. Triacylglycerols can be quickly hydrolyzed to provide energy for short-term needs. In contrast, wax esters are carefully regulated by wax ester lipases, allowing for their slower utilization rates during diapause and reproduction.

Sargent \& Henderson (1986) hypothesized that wax esters are mobilized by a hormone-sensitive lipase. It seems likely that hormones play an important role in the regulation of wax ester utilization, particularly during reproduction, when there is a high energy demand. Triacylglycerols can account for up to $20 \%$ of total lipid in wax-ester- rich herbivorous copepods during their active feeding period, but during diapause they become a minor lipid component. When copepods leave diapause in late winter or spring to begin reproduction, triacylglycerol content again increases, suggesting that wax esters are converted to triacylglycerols for reproductive needs (Sargent \& Henderson 1986, Heath \& Jónasdóttir 1999, Jónasdóttir 1999, Richardson et al. 1999).

\section{LIPID STORAGE IN DIFFERENT OCEAN BIOMES}

Since lipid storage patterns strongly differ in various regions it is important to compare lipid levels and compositions of zooplankton collected in different ocean biomes and provinces. Based on a number of ecological factors, Longhurst (1998) divided the ocean into 4 major biomes: polar, westerlies, trades/tropical and coastal biomes. These major biome categories are further subdivided into smaller units, e.g. the polar biome includes the Atlantic, Pacific and Antarctic biomes. Within each biome are a number of provinces with different biogeochemical characteristics, which led Longhurst (1998) to partition the ocean into 51 provinces. Estuaries within the coastal biome are somewhat different from other provinces of this biome since they are characterized by large numbers of meroplanktonic larvae with lipid stores (Holland \& Walker 1975, Lucas et al. 1979). Sufficient studies have been carried out to allow general statements on the importance of storage lipids in the major biomes. However, zooplankton from a number of provinces has not been investigated with respect to lipid accumulation, especially within the Indian Ocean biomes.

\section{Polar biome}

Characteristic features of provinces within the polar biome are winter ice cover, seasonally migrating marginal ice zones, ice algae and a relatively short spring/ summer primary production period. In general, a variety of zooplankton groups, e.g. crustaceans and pteropods, show a pronounced lipid accumulation during summer phytoplankton blooms (Hagen 1988, Hagen \& Schnack-Schiel 1996, Falk-Petersen et al. 2000, Gannefors et al. 2005, Böer et al. 2005). There is some evidence of lipid accumulation in the boreal chaetognaths Parasagitta elegans and Eukrohnia hamata during the spring/summer phytoplankton blooms (Båmstedt 1978, Choe et al. 2003) and in Arctic ctenophores during feeding on copepods (Falk-Petersen et al. 2002, Lundberg 2003). While the Arctic is characterized by large populations of diapausing copepods, which overwinter in deep waters, Antarctic waters are usually inhabited by large euphausiid populations, which do not undergo diapause but remain in surface waters during winter (Falk-Petersen et al. 2000).

Antarctic euphausiids accumulate different storage lipids (Tables $3 \& 8$ ) and do not reach the very high lipid levels found in many polar copepods (Tables 5 to 7). In addition to the copepods, most Arctic planktonic crustaceans, such as the amphipods Themisto libellula and $T$. abyssorum, have large lipid stores, up to $42 \% \mathrm{DM}, 41$ to $43 \%$ of them being wax esters (Auel et al. 2002). While wax esters are the predominant storage lipid in most polar zooplankton (Conover \& Huntley 1991, Albers et al. 1996), triacylglycerols are an

Table 6. Total lipid and storage lipid class data of Arctic copepods (C4 to females [f]; Svalbard, Aug-Sept) (Scott et al. 2000)

\begin{tabular}{|lccccc|}
\hline Species & Stage & $\begin{array}{c}\text { Lipid mass } \\
\left(\mu g \text { ind. }^{-1}\right)\end{array}$ & $\begin{array}{c}\text { Total lipid } \\
(\% \mathrm{DM})\end{array}$ & $\begin{array}{c}\text { WE } \\
(\% \mathrm{TL})\end{array}$ & $\begin{array}{r}\text { TAG } \\
(\% \mathrm{TL})\end{array}$ \\
\hline Calanus & $\mathrm{C} 4$ & 20 & 53 & 44 & 10 \\
finmarchicus & $\mathrm{C} 5$ & 50 & 34 & 68 & 5 \\
& $\mathrm{f}$ & 50 & 24 & 62 & 6 \\
& & & & & \\
Calanus & $\mathrm{C} 4$ & 40 & 56 & 68 & 2 \\
glacialis & $\mathrm{C} 5$ & 400 & 62 & 72 & 6 \\
& $\mathrm{f}$ & 480 & 70 & 68 & 8 \\
Calanus & $\mathrm{C} 4$ & 240 & 54 & 72 & 4 \\
hyperboreus & $\mathrm{C} 5$ & 1200 & 65 & 75 & 8 \\
& $\mathrm{f}$ & 1800 & 62 & 75 & 6 \\
\hline
\end{tabular}


Table 7. Total lipid and storage lipid class data of copepod genera from different biomes (+: trace amounts)

\begin{tabular}{|c|c|c|c|c|c|c|}
\hline Species and stage $\mathrm{L}$ & $\begin{array}{l}\text { Lipid mass } \\
\left(\mu \mathrm{g} \text { ind } .^{-1}\right)\end{array}$ & $\begin{array}{l}\text { Total lipid } \\
\text { (\%DM) }\end{array}$ & $\begin{array}{l}\text { WE } \\
(\% \mathrm{TL})\end{array}$ & $\begin{array}{l}\text { TAG } \\
(\% \mathrm{TL})\end{array}$ & Location & Source \\
\hline \multicolumn{7}{|l|}{ Rhincalanus } \\
\hline R. gigas C5 & 390 & 30 & 75 & 2 & Antarctic $\left(64^{\circ} \mathrm{S}\right)$ & $\begin{array}{l}\text { Kattner et al. (1994), Schnack-Schiel \& } \\
\text { Hagen (1994) }\end{array}$ \\
\hline$R$. gigas $\mathrm{f}$ & 400 & 69 & 92 & 1 & Antarctic $\left(53^{\circ} \mathrm{S}\right)$ & Lee \& Hirota (1973) \\
\hline$R$. nasutus $\mathrm{f}$ & 120 & 42 & 69 & 9 & N Pacific $\left(31^{\circ} \mathrm{N}\right)$ & Lee \& Hirota (1973) \\
\hline R. nasutus $\mathrm{f}$ & 68 & 31 & 87 & 3 & Red Sea $\left(21-28^{\circ} \mathrm{N}\right)$ & Sommer et al. (2002), Hagen (unpubl. data) \\
\hline \multicolumn{7}{|l|}{ Metridia } \\
\hline M. gerlachei C5 & 33 & 16 & 27 & 19 & Antarctic $\left(72-78^{\circ} \mathrm{S}\right)$ & Graeve et al. (1994a) \\
\hline M. gerlacheif & 59 & 19 & 42 & 22 & Antarctic $\left(72-78^{\circ} \mathrm{S}\right)$ & Graeve et al. (1994a) \\
\hline M. longa f & 200 & 57 & 76 & 10 & $\operatorname{Arctic}\left(84-88^{\circ} \mathrm{N}\right)$ & Lee $(1975)$ \\
\hline M. princeps $\mathrm{f}$ & 100 & 12 & 41 & 4 & N Pacific $\left(31^{\circ} \mathrm{N}\right)$ & Lee et al. (1971a) \\
\hline M. okhotensis f & 367 & 75 & 91 & 3 & N Pacific $\left(38^{\circ} \mathrm{N}\right)$ & Saito \& Kotani (2000) \\
\hline \multicolumn{7}{|l|}{ Euchirella } \\
\hline E. rostromagna C5 & 1600 & 45 & 89 & 7 & Antarctic $\left(72-78^{\circ} \mathrm{N}\right)$ & Hagen et al. (1995) \\
\hline E. rostromagna f & 1900 & 42 & 94 & 3 & Antarctic $\left(72-78^{\circ} \mathrm{N}\right)$ & Hagen et al. (1995) \\
\hline E. rostrata $\mathrm{f}, \mathrm{m}$ & 140 & 21 & 0 & 37 & N Pacific $\left(31^{\circ} \mathrm{N}\right)$ & Lee et al. (1971a) \\
\hline E. galeata f & 60 & 4 & 0 & 14 & N Pacific $\left(31^{\circ} \mathrm{N}\right)$ & Lee et al. (1971a) \\
\hline E. pulchra f & 50 & 12 & 2 & 18 & N Pacific $\left(31^{\circ} \mathrm{N}\right)$ & Lee et al. (1971a) \\
\hline E. brevis C5 & 70 & 27 & 7 & 16 & S Pacific $\left(24^{\circ} \mathrm{S}\right)$ & Lee \& Hirota (1973) \\
\hline E. brevis $\mathrm{f}$ & 60 & 17 & + & 11 & S Pacific $\left(24^{\circ} \mathrm{S}\right)$ & Lee \& Hirota (1973) \\
\hline \multicolumn{7}{|c|}{ Euchaeta, Paraeuchaeta } \\
\hline E. antarctica C5 & 1600 & 45 & 89 & 7 & Antarctic $\left(72-75^{\circ} \mathrm{S}\right)$ & Hagen et al. (1995) \\
\hline E. antarctica f & 2000 & 42 & 94 & 3 & Antarctic $\left(72-75^{\circ} \mathrm{S}\right)$ & Hagen et al. (1995) \\
\hline E. norvegica C5 & 1040 & 43 & 60 & 15 & $\mathrm{~N}$ Atlantic $\left(60^{\circ} \mathrm{N}\right)$ & Sargent et al. (1974) \\
\hline E. norvegica f & 1410 & 47 & & & N Atlantic $\left(60^{\circ} \mathrm{N}\right)$ & Båmstedt \& Matthews (1975) \\
\hline E. japonica C5 & 520 & 50 & 81 & 2 & N Pacific $\left(50^{\circ} \mathrm{N}\right)$ & Lee et al. (1974) \\
\hline E. japonica f & 600 & 52 & 60 & 17 & N Pacific $\left(50^{\circ} \mathrm{N}\right)$ & Lee et al. (1974) \\
\hline P. barbata f & 1800 & 48 & 68 & 9 & $\operatorname{Arctic}\left(83-88^{\circ} \mathrm{N}\right)$ & Lee (1975) \\
\hline P. glacialis $\mathrm{f}$ & 500 & 43 & 72 & 9 & Arctic $\left(83-88^{\circ} \mathrm{N}\right)$ & Lee (1975) \\
\hline P. rubra f & 1600 & 57 & 65 & 11 & N Pacific $\left(31^{\circ} \mathrm{N}\right)$ & Lee et al. (1971a) \\
\hline E. marina $\mathrm{f}, \mathrm{m}$ & 30 & 29 & 31 & 4 & S Atlantic $\left(24^{\circ} \mathrm{S}\right)$ & Lee \& Hirota (1973) \\
\hline \multicolumn{7}{|c|}{ Calanus, Neo-, Eucalanus } \\
\hline C. propinquus $\mathrm{f}$ & 720 & 45 & 3 & 91 & Antarctic $\left(70-75^{\circ} \mathrm{S}\right)$ & $\begin{array}{l}\text { Kattner et al. (1994a), Falk-Petersen } \\
\quad \text { et al. (1999) }\end{array}$ \\
\hline C. hyperboreus $\mathrm{f}$ & 2100 & 66 & 91 & 4 & $\operatorname{Arctic}\left(88^{\circ} \mathrm{N}\right)$ & Lee $(1974 b)$ \\
\hline C. hyperboreus $\mathrm{f} 1$ & 1800-2000 & $47-62$ & 75 & 6 & $\operatorname{Arctic}\left(78-79^{\circ} \mathrm{N}\right)$ & Scott et al. (2000), Auel et al. (2003) \\
\hline C. glacialis $\mathrm{f}$ & 480 & 70 & 68 & 8 & $\operatorname{Arctic}\left(78^{\circ} \mathrm{N}\right)$ & Scott et al. $(2000)$ \\
\hline C. finmarchicus $\mathrm{f}$ & 50 & 31 & 62 & 6 & $\operatorname{Arctic}\left(78^{\circ} \mathrm{N}\right)$ & Scott et al. (2000) \\
\hline C. finmarchicus $\mathrm{f}$ & 80 & 40 & 60 & 10 & $\mathrm{~N}$ Atlantic $\left(60^{\circ} \mathrm{N}\right)$ & Jónasdóttir (1999) \\
\hline C. pacificus $\mathrm{f}$ & 70 & 27 & 20 & 2 & $\mathrm{~N}$ Pacific $\left(50^{\circ} \mathrm{N}\right)$ & Lee \& Hirota (1973) \\
\hline N. plumchrus f & 410 & 59 & 86 & 7 & N Pacific $\left(50^{\circ} \mathrm{N}\right)$ & Lee \& Hirota (1973) \\
\hline N. flemingeri C5 & 287 & 53 & 88 & 6 & N Pacific $\left(38^{\circ} \mathrm{N}\right)$ & Saito \& Kotani (2000) \\
\hline E. bungiif & 352 & 32 & 10 & 80 & N Pacific $\left(38^{\circ} \mathrm{N}\right)$ & Saito \& Kotani (2000) \\
\hline C. pacificus C5 & 15 & 20 & 50 & 5 & N Pacific $\left(33^{\circ} \mathrm{N}\right)$ & Håkanson (1984) \\
\hline C. gracilis $\mathrm{f}$ & 80 & 26 & 21 & 17 & N Pacific $\left(33^{\circ} \mathrm{N}\right)$ & Lee \& Hirota (1973) \\
\hline C. robustior $\mathrm{f}$ & 30 & 8 & 21 & 3 & N Pacific $\left(33^{\circ} \mathrm{N}\right)$ & Lee \& Hirota (1973) \\
\hline C. gracilis $\mathrm{f}$ & 30 & 11 & 31 & 8 & S Pacific $\left(24^{\circ} \mathrm{S}\right)$ & Lee \& Hirota (1973) \\
\hline C. minor $\mathrm{f}$ & 1 & 3 & + & 3 & S Pacific $\left(24^{\circ} \mathrm{S}\right)$ & Lee \& Hirota (1973) \\
\hline N. tonsus f & 162 & 34 & 90 & 1 & S Pacific $\left(45^{\circ} \mathrm{S}\right)$ & Ohman (1987), Ohman et al. (1989) \\
\hline
\end{tabular}


Table 8. Total lipid and storage lipid class data of euphausiids from different biomes

\begin{tabular}{|c|c|c|c|c|c|c|}
\hline Species & 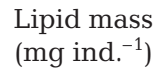 & $\begin{array}{c}\text { Total lipid } \\
\text { (\%DM) }\end{array}$ & $\begin{array}{c}\text { WE } \\
(\% \mathrm{TL})\end{array}$ & $\begin{array}{l}\text { TAG } \\
(\% \mathrm{TL})\end{array}$ & Location & Source \\
\hline \multicolumn{7}{|l|}{ Euphausia } \\
\hline E. superba & 34.9 & 27 & - & 49 & Antarctic $\left(73^{\circ} \mathrm{S}\right)$ & Hagen (1988) \\
\hline E. superba & 74.0 & 44 & - & 51 & Antarctic $\left(69^{\circ} \mathrm{S}\right)$ & Atkinson et al. (2002) \\
\hline E. crystallorophias & 10.5 & 34 & 47 & 6 & Antarctic $\left(73^{\circ} \mathrm{S}\right)$ & Hagen (1988) \\
\hline E. crystallorophias & 8.4 & 34 & 47 & 6 & Antarctic $\left(70^{\circ} \mathrm{S}\right)$ & Falk-Petersen et al. (1999) \\
\hline E. lucens & 0.9 & 5 & - & 2 & N Atlantic $\left(15^{\circ} \mathrm{N}\right)$ & Kattner et al. (unpubl. data) \\
\hline E. gibboides & 1.8 & 10 & - & 8 & S Atlantic $\left(18^{\circ} \mathrm{S}\right)$ & Kattner et al. (unpubl. data) \\
\hline E. pacifica & 2.3 & 19 & 1 & 17 & $\mathrm{~N}$ Pacific $\left(50^{\circ} \mathrm{N}\right)$ & Lee $(1974 a)$ \\
\hline E. recurva & 0.4 & 7 & + & 21 & S Pacific $\left(24^{\circ} \mathrm{S}\right)$ & Lee \& Hirota (1973) \\
\hline E. americana & 0.1 & & - & - & Gulf of Mexico & Morris \& Hopkins (1983) \\
\hline \multicolumn{7}{|l|}{ Thysanoessa } \\
\hline T. macrura & 6.3 & 37 & 56 & 2 & Antarctic $\left(73^{\circ} \mathrm{S}\right)$ & Hagen (1988) \\
\hline T. raschii & - & 23 & - & - & $\mathrm{N}$ Pacific $\left(50^{\circ} \mathrm{N}\right)$ & Sargent \& Lee (1975) \\
\hline T. raschii & - & 38 & 10 & 44 & N Atlantic $\left(70^{\circ} \mathrm{N}\right)$ & Falk-Petersen (1981) \\
\hline T. inermis & - & 47 & 40 & 28 & $\mathrm{~N}$ Atlantic $\left(70^{\circ} \mathrm{N}\right)$ & Falk-Petersen (1981) \\
\hline
\end{tabular}

important storage lipid in Antarctic species such as Euphausia superba, Calanus propinquus, C. simillimus, Stephos longipes and Euchirella rostromagna (Tables 7 \& 8) (Hagen 1988, Schnack-Schiel et al. 1991, Hagen et al. 1993, Ward et al. 1996).

Most ice-associated zooplankton in polar regions are high in triacylglycerols rather than wax esters. Cryopelagic amphipods (Gammarus wilkitzkii, Apherusa glacialis, Onisimus nanseni, O. glacialis) and copepods (Jaschnovia brevis), which live in the Arctic sea ice, have lipid contents ranging from 28 to $51 \%$ DM (Scott et al. 1999, 2001, 2002, Scott 2000). This appears to be also true for the Antarctic ice-associated copepods Stephos longipes and Paralabidocera antarctica (Schnack-Schiel et al. 1995, Swadling 2000). Species with large triacylglycerol stores do not undergo a winter diapause.

In addition to wax esters and triacylglycerols, the polar biomes have zooplankton with 2 unusual storage lipids, diacylglycerol ethers and phosphatidylcholine. Large amounts of diacylglycerol ethers have been found in the pteropod Clione limacina from both Arctic and Antarctic waters (Phleger et al. 1997, Kattner et al. 1998, Falk-Petersen et al. 2001, Böer et al. 2005). The Antarctic euphausiids Euphausia superba, E. triacantha and Thysanoessa macrura use phospholipids, primarily phosphatidylcholine, as a storage lipid (Hagen et al. 1996, Stübing 2004). Thus, E. superba has stores of both triacylglycerols and phosphatidylcholine. There is also some evidence that phospholipids play a storage function in the subarctic and Arctic euphausiids Thysanoessa inermis and T. raschii (Saether et al. 1986).

While most crustacean species in polar provinces have high lipid concentrations, several groups including cnidarians, ctenophores and tunicates do not accumulate significant amounts of storage lipids (Table 4).
However, oil droplets have been observed in the gastrovascular system of polar medusae and ctenophores (Larson \& Harbison 1989). It was suggested that these oil droplets were obtained from their prey, e.g. lipidrich Calanus, since the oil droplets were absent from non-digestive tissues and rapidly disappeared during starvation. Salps grow rapidly and reproduce asexually during phytoplankton blooms but do not convert excess food into storage lipids. Salpa thompsoni from the Antarctic contained only 0.9\%DM lipid (Hagen 1988, Phleger et al. 1998). A year with high abundance of $S$. thompsoni is generally a year with relatively low numbers of Euphausia superba (Loeb et al. 1997). Large salp populations are associated with winters of low ice cover, which results in an early spring bloom, and this allows an early and rapid increase of the salp population (Longhurst 1998). In contrast, large populations of E. superba occurred during heavy ice winters, which is associated with intensive spawning. It is interesting that these 2 zooplankton groups, both of which are primarily herbivorous, differ markedly in their different strategies with respect to lipid storage. Ohman et al. (1998) found very different seasonal dormancy patterns for 4 copepod species (Eucalanus californicus, Rhincalanus nasutus, Calanus pacificus, Metridia pacifica) in the California Current Province. C. pacificus in winter had dormant adults in deep water with more wax esters than actively reproducing adults in surface waters. The authors described this species as having a biphasic life history. In contrast, $M$. pacifica adult females with relatively low wax esters and triacylglycerols showed no evidence of dormancy. Adults and copepodid stage $\mathrm{V}$ of wax-ester-rich $R$. nasutus and triacylglycerol-rich E. californicus were dormant in winter but responded rapidly to changes in food availability. 


\section{Coastal boundary zone biome}

It is difficult to generalize about this biome since its provinces are quite diverse. They range from coral reefs in the tropical coastal areas to the relatively shallow Baltic Sea in the North Atlantic coastal zones. Upand downwelling is a feature of several provinces in this biome, including the Alaska Downwelling Coastal Province, the California Current Province, the Northwest Arabian Upwelling Province and the Benguela Current Coastal Province. Coastal zone province species and their lipid data are listed in Tables 4, 5, 7 \& 8 and Fig. 19. Upwelling of nutrient-rich waters results in phytoplankton blooms, followed by phytoplankton decreases after depletion of nutrients. There is a buildup of storage lipids by Calanus spp. during upwelling followed by descent and diapause during non-upwelling periods (Table 5). Experimental evidence showed that C. pacificus lipid levels increased linearly as the copepod was offered increasing concentrations of the diatom Skeletonema costatum (Fig. 20a). A field study of wax ester accumulation by $C$. pacificus in the California Current Province gave results similar to those observed in the experimental study (Håkanson 1987). The wax ester content of the copepods at each collection site closely correlated with the different primary production rates (Fig. 20b). Wax esters are the dominant lipid class in diapausing copepods from upwelling areas, but other zooplankton in this biome often have triacylglycerols as the major storage lipid (Tables 4, 7 \& 8), including lecithotrophic meroplanktonic larvae with large lipid stores (Kattner et al. 2003).

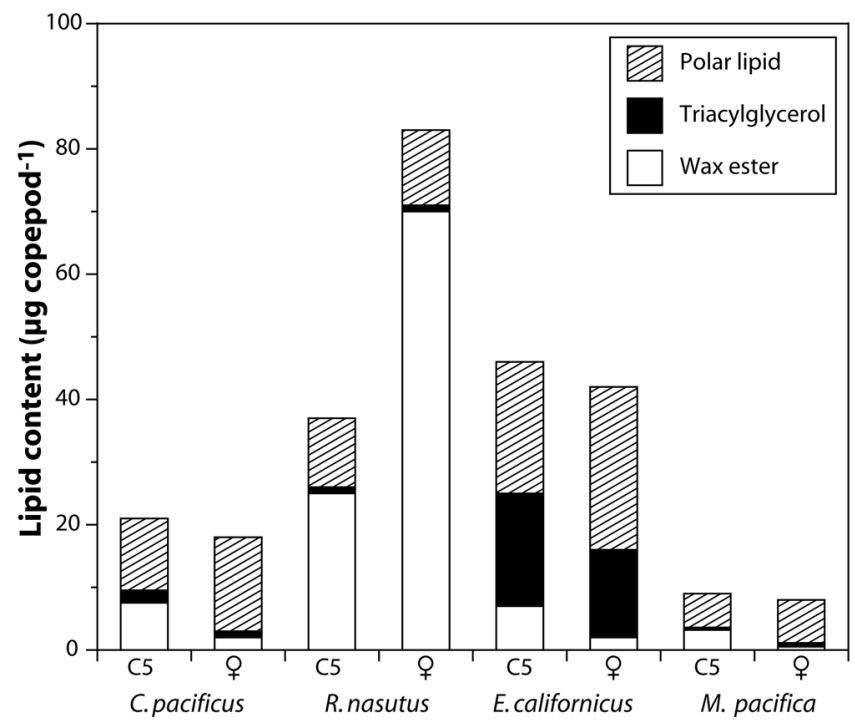

Fig. 19. Wax ester, triacylglycerol and polar lipid levels ( $\mu g$ per stage) of C5 and adults of different copepod species (Calanus pacificus, Rhincalanus nasutus, Eucalanus californicus, Metridia pacifica) from California Current. With permission from Ohman (1988)
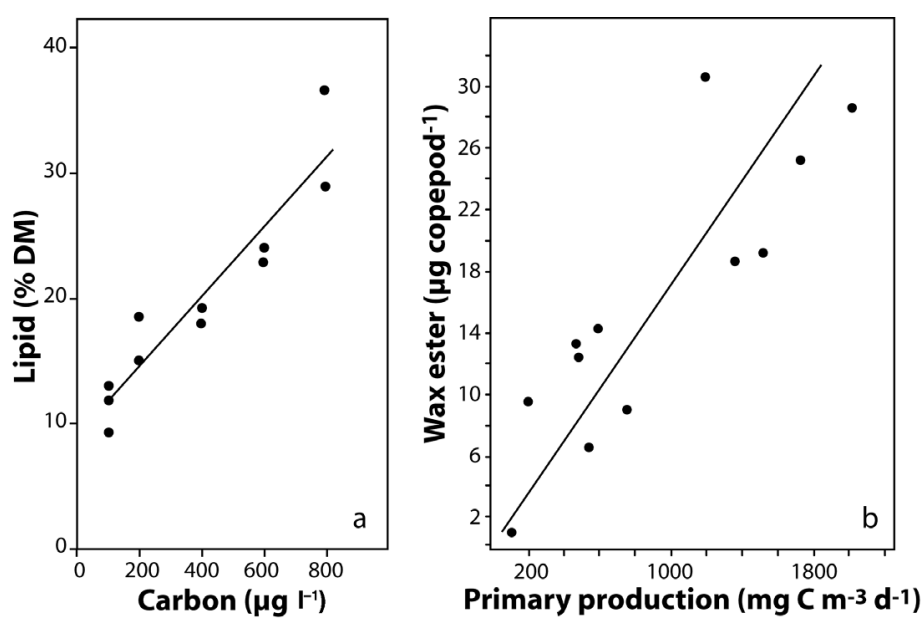

Fig. 20. Calanus pacificus (C5). (a) Lipid content (\%DM) vs. concentration ( $\mu \mathrm{g} \mathrm{C}^{-1}$ ) of food (Skeletonema costatum). With permission from Lee et al. (1971b). (b) Mean wax ester levels vs. integrated primary production $\left(\mathrm{mg} \mathrm{C} \mathrm{m}^{-2} \mathrm{~d}^{-1}\right)$ in California Current. With permission from Håkanson (1987)

Estuaries fit into the coastal boundary zone biome with some unique features with respect to zooplankton and lipid. Estuaries are characterized by 2 groups of zooplankton. The first is holoplanktonic, and the entire life cycle takes place in the plankton. This group is characterized by zooplankton with low amounts of storage lipid, e.g. Acartia sp., Eurytemora affinis (Table 4) (Harris et al. 1977). However, the polar estuarine copepod Limnocalanus macrurus has high lipid levels composed primarily of wax esters (Hirche et al. 2003). The second zooplankton group comprises meroplanktonic larvae of benthic invertebrates. These meroplanktonic species are characterized by larvae with significant energy reserves in the form of lipid globules. They provide the energy required during the settling phase and metamorphosis. Triacylglycerols are the primary form of storage lipid for the estuarine zooplankton (Holland $\&$ Walker 1975). An exception are the lecithotrophic lipid-rich non-feeding planktonic larvae of the sea urchin Heliocidaris erythrogramma, which are high in wax esters (Villinski et al. 2002).

\section{Westerlies biome}

Provinces in this biome have pronounced seasonal cycles in phytoplankton productivity. All of the provinces except subarctic and subantarctic iron-limited HNLC regions (high nutrient, low chlorophyll) are characterized by a spring bloom, after nutrients from deeper waters have been transported to the surface during winter. By summer the nutrients are depleted, and in fall there can be a small autumn bloom as a 
result of the vertical nutrient flux. Spring blooms are associated with zooplankton species that accumulate storage lipid, and some of the copepods descend to depths in summer and fall. These diapausing copepods accumulate wax esters as the principal storage lipid, but many of the other zooplankton groups, including a number of euphausiid and copepod species, store primarily triacylglycerols (Tables 7 \& 8) (Kattner et al. 1981). During summer and winter there are resident species that do not accumulate lipid deposits such as the copepod Centropages typicus (Table 4).

\section{Trade/tropical biome}

This biome is associated with low nutrient concentrations and relatively low primary production rates throughout the year and thus does not have the large blooms found in the polar and westerlies biomes. While larger herbivorous species represent the characteristic feeding type in the polar biome, omnivores and carnivores are dominant in the trade/tropical biome (Longhurst 1998). Zooplankters of this biome tend to be small and lipid-poor with deposits consisting primarily of small amounts of triacylglyerols (Tables 4, $7 \&$ 8) (Lee \& Hirota 1973, Kattner et al. unpubl. data). There is a lipid gradient with maxima in polar species and minima in related tropical species. For example, the subtropical Euchaeta marina has a lipid content of $7.8 \% \mathrm{DM}$ in the Gulf of Mexico (Morris \& Hopkins 1983), while polar Euchaeta species range from 42 to $45 \%$ lipid (Table 7 ). The same holds true for euphausiid and pteropod species, which are lipid-rich in high latitudes but in tropical regions contain only small amounts of lipids. The low proportions of neutral lipids are triacylgycerols, whereas phospholipids, as structural membrane components, are the dominant lipid class (Kattner et al. unpubl. data). Knowledge about lipid and fatty acid compositions of tropical zooplankton is sparse. Based on some unpublished data we assume that the variability in lipid accumulation and lipid class and fatty acid compositions is small. These data must be approached with caution due to extremely high proportions of free fatty acids and sterols (Attwood \& Hearshaw 1992, Yuneva et al. 1993), which point to lyses of lipids during sample preparation due to very active lipases in the animals probably related to the high ambient temperatures.

\section{DISCUSSION AND FUTURE DIRECTIONS}

Many questions remain concerning the role and importance of lipids in marine zooplankton. As noted above, many zooplankton groups, especially a number of copepod species in cold-water habitats, can convert low-lipid phytoplankton into large lipid stores. Few studies have determined the minimum amount of food required before lipid accumulation occurs. Lipid stores allow zooplankton to survive during periods of food scarcity. Copepods, undergoing diapause in cold deep water, often have very low rates of metabolism and often utilize only minor amounts of their large lipid stores during diapause. However, when reproduction takes place at depth in winter, lipid utilization increases, and the energy and materials needed for reproduction are provided by lipid stores. Other species that reproduce during phytoplankton blooms have less need for lipid, but there remains the question as to how these species cope with situations where food levels are inadequate during the reproduction period. Are these species able to interrupt gonad maturation during a period of insufficient food? Some species that reproduce during phytoplankton blooms still contain lipid stores. Perhaps these lipid stores function as a supplement when food quality or quantity is poor. Lipovitellin is an important constituent of most zooplankton eggs, and when there is inadequate food only limited amounts of this compound can be synthesized by the female. Some species can survive by body shrinkage, e.g. krill, utilizing all their biochemical constituents. Other successful zooplankton use all their food for growth and maintence rather than convert excess food into lipid stores. More knowledge about their life history may help in understanding why different zooplankton species employ very different strategies with respect to lipid accumulation.

A long history of controversy concerns the relative importance of lipids in buoyancy and storage in zooplankton. An active discussion on the use of lipids for buoyancy regulation in diapausing copepods is ongoing since both body composition and lipid compressibility may be important factors. Work needs to be carried out on the thermocompressibility of common storage lipids, i.e. triacylglycerols, diacylglycerol ethers and wax esters, to better understand density changes of these different types of lipid in various zooplankton groups and their possible role in buoyancy.

In addition to more chemical characterization of zooplankton storage lipids, more histology work needs to be carried out as well as more work on metabolic pathways involving lipids. It would be useful to isolate and culture copepod oil sac cells to determine their role in the synthesis and utilization of oil sac lipids. More ultrastructural studies of tissues with lipid stores will provide more insight into the various storage sites of zooplankton, for example, a determination of whether phosphatidylcholine in high-latitude euphausiids is stored in lipid micelles, lipoproteins or perhaps unique vesicles. Further work is warranted on the use of phospholipids as energy reserves. 
Besides euphausiids do other zooplankton groups utilize phospholipids for storage? Is the structure of storage phosphatidylcholine different from that of membrane phosphatidylcholine, i.e. fatty acids of the glycerol backbone? What are the essential fatty acids of zooplankton? An unsettled issue concerns the ability of some zooplankton groups, e.g. protozoans, to perform de novo synthesis of the polyunsaturated n-3 fatty acids. Crustacean zooplankton do not synthesize these polyunsaturated acids, which play an important role in zooplankton membranes, but obtain them from their diet. In light of the importance of egg lipovitellin for the survival of many zooplankton embryos more work is needed on the isolation and characterization of lipovitellin from such zooplankton groups as pteropods, chaetognaths and salps.

A future topic that needs to be addressed is the impact of climate change on zooplankton communities, specifically the effects on lipid-storing species. It has been suggested that during warming periods, warmwater species with lower lipid stores invade ocean areas normally inhabited by high-lipid cold-water forms. This will not only impact the plankton community but also affect the energy flux of the entire system. The increase in solar ultraviolet radiation and its effects on surface-living zooplankton is a much discussed topic. The high content of polyunsaturated fatty acids in zooplankton suggests that an increase in ultraviolet radiation would likely lead to increases in the photo-oxidation rates of zooplankton lipids. The toxicity of oxidized polyunsaturated lipids, as well as the damage caused by free radicals produced during lipid photo-oxidation, are well known from the medical literature. Work remains to be done to show that increased ultraviolet exposure results in effects on the zooplankton community due to increased lipid photooxidation rates.

Acknowledgements. This work was supported by a fellowship for R.F.L. through the Hanse-Wissenschaftskolleg/ Hanse Institute of Advanced Study, Delmenhorst, Germany. We thank Hiroaki Saito for sending a photomicrograph of copepod nauplii. We are grateful to 4 reviewers for helpful comments and suggestions.

\section{LITERATURE CITED}

Ackman RG (1981) Problems in introducing new chromatographic techniques for lipid analyses. Chem Ind 20: 715-722

Ackman RG (1999) Comparison of lipids in marine and freshwater organisms. In: Arts MT, Wainman BC (eds) Lipids in freshwater ecosystems. Springer, Berlin, p 263-298

Ackman RG, Eaton CA, Sipos JC, Hooper SN, Castell JD (1970) Lipids and fatty acids of two species of North Atlantic krill (Meganyctiphanes norvegica and Thysa- noessa inermis) and their role in the aquatic food web. J Fish Res Bd Can 27:513-533

Albers CS, Kattner G, Hagen W (1996) The compositions of wax esters, triacylglycerols and phospholipids in Arctic and Antarctic copepods: evidence of energetic adaptations. Mar Chem 55:347-358

Albessard E, Mayzaud P, Cuzin-Roudy J (2001) Variation of lipid classes among organs of the Northern krill Meganyctiphanes norvegica, with respect to reproduction. Comp Biochem Physiol 129A:373-390

Aldredge AL, Robinson BH, Fleminger A, Torres JJ, King JM, Hamner WM (1984) Direct sampling and in situ observation of a persistent copepod aggregation in the mesopelagic zone of the Santa Barbara Basin. Mar Biol 80: 75-81

Al-Mohanna SY, Nott JA (1987) R-cells and the digestive cycle in Penaeus semisulcatus (Crustacea: Decapoda). Mar Biol 95:129-137

Al-Mohanna SY, Nott JA (1989) Functional cytology of the hepatopancreas of Penaeus semisulcatus (Crustacea: Decapoda) during the moult cycle. Mar Biol 101:535-544

Alonzo F, Mayzaud P (1999) Spectrofluorometric quantification of neutral and polar lipids in zooplankton using Nile red. Mar Chem 67:289-301

Alonzo F, Mayzaud P, Razouls S (2000a) Egg production, population structure and biochemical composition of the subantarctic copepod Paraeuchaeta antarctica in the Kerguelen Archipelago. Mar Ecol Prog Ser 205:207-217

Alonzo F, Mayzaud P, Razouls S (2000b) Egg-production dynamics, biochemical composition and hatching success of the subantarctic copepod Paraeuchaeta antarctica: laboratory studies. Mar Ecol Prog Ser 205:219-227

Amsler MO, George RY (1985) Changes in the biochemical composition of Euphausia superba Dana embryos during early development. Polar Biol 4:61-63

Arashkevich EG, Drits AV (1997) Ecological-physiological indices of Calanoides carinatus (Krøyer) from the Benguela upwelling region: biochemical composition, respiration rate, and gonad development of various life stages. Oceanol 37:513-519

Arashkevich EG, Drits AV, Timonin AG (1996) Diapause in the life cycle of Calanoides carinatus (Krøyer) (Copepoda, Calanoida). Hydrobiol 320:197-208

Arashkevich EG, Tande KS, Pasternak AF, Ellertsen B (2004) Seasonal moulting patterns and the generation cycle of Calanus finmarchicus in the NE Norwegian Sea, as inferred from gnathobase structures, and the size of gonads and oil sacs. Mar Biol 146:119-132

Armenta JD (1964) A rapid chemical method for quantification of lipids separated by thin-layer chromatography. J Lipid Res 5:270-273

Arnaud J, Brunet M, Mazza J (1978) Studies on the midgut of Centropages typicus (Copepod, Calanoid). Cell Tissue Res 187:333-353

Arnaud J, Brunet M, Mazza J (1980) Structure et ultrastructure comparees de l'intestin chez plusieurs especes de Copepodes Calanoides (Crustacea). Zoomorphologie 95: 213-233

Arts MT (1999) Lipids in freshwater zooplankton: selected ecological and physiological aspects. In: Arts MT, Wainman BC (eds) Lipids in freshwater ecosystems. Springer, Berlin, p 71-90

Arts MT, Evans MS (1991) Optical-digital measurements of energy reserves in calanoid copepods -intersegmental distributions and seasonal patterns. Limnol Oceanogr 36: 289-298

Atkinson A, Meyer B, Stübing D, Hagen W, Schmidt K, Bath- 
mann UV (2002) Feeding and energy budgets of Antarctic krill Euphausia superba at the onset of winter. II. Juveniles and adults. Limnol Oceanogr 47:953-966

Attwood CG, Hearshaw KD (1992) Lipid content and composition of sub-Antarctic euphausiids and copepods from the Prince Edward Islands. S Afr J Antarct Res 22:3-13

Attwood CG, Peterson WT (1989) Reduction in fecundity and lipids of the copepod Calanus australis (Brodskii) by strongly pulsed upwelling. J Exp Mar Biol Ecol 129: 121-131

Auel H, Harjes M, da Rocha R, Stübing D, Hagen W (2002) Lipid biomarkers indicate different ecological niches and trophic relationships of the Arctic hyperiid amphipods Themisto abyssorum and T. libellula. Polar Biol 25: 374-383

Auel H, Klages M, Werner I (2003) Respiration and lipid content of the Arctic copepod Calanus hyperboreus overwintering $1 \mathrm{~m}$ above the seafloor at 2,300 $\mathrm{m}$ water depth in the Fram Strait. Mar Biol 143:275-282

Båmstedt U (1978) Studies on the deep-water pelagic community of Korsfjorden, western Norway. Seasonal variation in weight and biochemical composition of Chiridius armatus (Copepoda), Boreomysis arctica (Mysidacea), and Eukrohnia hamata (Chaetognatha) in relation to their biology. Sarsia 63:145-154

Båmstedt U (1979) Reproductive bioenergetics within the summer and winter generations of Euchaeta norvegica (Copepoda). Mar Biol 54:135-142

Båmstedt U (1984) Diel variations in the nutritional physiology of Calanus glacialis from Lat. $78^{\circ} \mathrm{N}$ in the summer. Mar Biol 79:257-267

Båmstedt U, Matthews JBL (1975) Studies of the deep-water pelagic community of Korsfjorden, western Norway. The weight and biochemical composition of Euchaeta norvegica Boeck in relation to its life cycle. In: Barnes $\mathrm{H}$ (ed) Proc 9th Eur Mar Biol Symp. Aberdeen University Press, Aberdeen, p 311-327

Båmstedt U, Håkanson JL, Brenner-Parsen J, Björnsen PK, Geertz-Hansen O, Tiselius P (1990) Copepod nutrition and pelagic production during autumn in Kosterfjorden, western Sweden. Mar Biol 104:197-208

Bauermeister AEM, Sargent JR (1979) Wax esters: major metabolites in the marine environment. Trends Biochem Sci 4:209-211

Benson AA, Lee RF, Nevenzel JC (1972) Wax esters: major marine metabolic energy source. In: Ganguly J, Smellie RMS (eds) Current trends in the biochemistry of lipids. Academic, London, p 175-187

Bergen BJ, Quinn JG, Parrish CC (2000) Quality-assurance study of marine lipid-class determination using Chromarod/Iatroscan thin-layer chromatography - flame ionization detector. Environ Toxicol Chem 19:2189-2197

Blades-Eckelbarger PI (1986) Aspects of internal anatomy and reproduction in the Copepoda. National Museum of Canada, Syllogeus 58:26-50

Blades-Eckelbarger PI (1991) Comparative ultrastructure of lipid storage sites in female Euchaeta marina and Pleuromamma xiphias (Copepoda: Calanoida). Mar Biol 108: 49-58

Blades-Eckelbarger PI, Youngbluth MJ (1984) The ultrastructure of oogenesis and yolk formation in Labidocera aestiva (Copepoda: Calanoida). J Morphol 179:33-46

Bligh EG, Dyer WJ (1959) A rapid method of total lipid extraction and purification. Can J Biochem Physiol 37:911-917

Blumer M, Mullin MM (1964) Pristane in the marine environment. Helgoland Wissen Meers 10:187-201

Böer M (2005) Die Flügelschnecke Clione limacina: außer- gewöhnliche Lipide als Anpassungsstrategie an den Lebensraum Arktis. PhD thesis, University of Bremen

Böer M, Gannefors C, Kattner G, Graeve M, Hop H, FalkPetersen S (2005) The Arctic pteropod Clione limacina: seasonal lipid dynamics and life strategy. Mar Biol 147: 707-717

Borchers P, Hutchings P (1986) Starvation tolerance, development time and egg production of Calanoides carinatus in the Southern Benguela Current. J Plankton Res 8:855-874

Boudier AG, Amblard CA (1989) Lipids in Acanthodiaptomus denticornis during starvation and fed on three different algae. J Plankton Res 11:1201-1212

Brett MT, Müller-Navarra DC (1997) The role of highly unsaturated fatty acids in aquatic foodweb processes. Freshw Biol 38:483-499

Butler NM (1994) Lipid storage in Diaptomus kenai (Copepoda: Calanoida): effects of inter- and intraspecific variation in food quality. Hydrobiol 274:9-16

Campbell RW, Dower JF (2003) Role of lipids in the maintenance of neutral buoyancy by zooplankton. Mar Ecol Prog Ser 263:93-99

Campbell RW, Boutillier P, Dower JF (2004) Ecophysiology of overwintering in the copepod Neocalanus plumchrus: changes in lipid and protein contents over a seasonal cycle. Mar Ecol Prog Ser 280:211-226

Carman KR, Thistle D, Ertman SC, Foy M (1991) Nile red as a probe for lipid-storage products in benthic copepods. Mar Ecol Prog Ser 74:307-311

Cavaletto JF, Vanderploeg HA, Gardner WS (1989) Wax esters in two species of freshwater zooplankton. Limnol Oceanogr 34:785-789

Choe N, Deibel D, Thompson RJ, Lee SH, Bushell VK (2003) Seasonal variation in the biochemical composition of the chaetognath Parasagitta elegans from the hyperbenthic zone of Conception Bay, Newfoundland. Mar Ecol Prog Ser 251:191-200

Christie WW (1982) Lipid analysis: isolation, separation, identification and structural analysis of lipids. Pergamon, Oxford

Christie WW (1989) Gas chromatography and lipids: a practical guide. Oily Press, Ayr

Christie WW (1997) Advances in lipid methodology - Four. Oily Press, Dundee

Clarke A (1980) The biochemical composition of krill, Euphausia superba Dana, from South Georgia. J Exp Mar Biol Ecol 43:221-236

Clarke A (1983) Life in cold water: the physiological ecology of polar marine ectotherms. Oceanogr Mar Biol Annu Rev 21:341-453

Clarke A (1984) Lipid content and composition of antarctic krill, Euphausia superba Dana. J Crust Biol 4 (Spec No 1): 285-294

Clarke A, Morris DJ (1983) Towards an energy budget for krill: the physiology and biochemistry of Euphausia superba Dana. Polar Biol 2:69-86

Claus C (1863) Die frei lebenden Copepoden. Engelmann, Leipzig, p 230

Conover RJ (1964) Food relations and nutrition of zooplankton. In: Symposium on experimental marine ecology. Occ Publ 2. University of Rhode Island, Kingston, RI, p 81-91

Conover RJ (1967) Reproduction cycle, early development, and fecundity in laboratory populations of the copepod Calanus hyperboreus. Crustaceana 13:61-75

Conover RJ (1988) Comparative life histories in the genera Calanus and Neocalanus in high latitudes of the northern hemisphere. Hydrobiol 167/168:127-142

Conover RJ, Corner EDS (1968) Respiration and nitrogen 
excretion by some marine zooplankton in relation to their life cycles. J Mar Biol Assoc UK 48:49-75

Conover RJ, Huntley M (1991) Copepods in ice-covered seas - distribution, adaptations to seasonally limited food, metabolism, growth patterns and life cycle strategies in polar seas. J Mar Syst 2:1-41

Conover RJ, Siferd TD (1993) Dark-season survival strategies of coastal zone zooplankton in the Canadian Arctic. Arctic 46:303-311

Corkett CJ, McLaren IA (1969) Egg production and oil storage by the copepod Pseudocalanus in the laboratory. J Exp Mar Biol Ecol 3:90-105

Corkett CJ, McLaren IA (1978) The biology of Pseudocalanus. Adv Mar Biol 15:1-231

Corkett CJ, McLaren IA, Sevigny JM (1986) The rearing of the marine calanoid copepods Calanus finmarchicus (Gunnerus), C. glacialis (Jaschnov) and C. hyperboreus (Krøyer) with comment of the equiproportional rule. In: Schriever G, Schminke HK, Shih CT (eds) Proc 2nd Int Conf Copepoda. National Museum of Canada, Ottawa, Syllogeus 59:539-546

Cosper TC, Reeve MR (1975) Digestive efficiency of the chaetognath Sagitta hispida. J Exp Mar Biol Ecol 17:33-38

Costlow JD (1982) Studies on molting and growth in larval and adult barnacles and larval decapods. In: Oceanic chemistry and biology group (ONR Code 422CB). Program Science Report, Office of Naval Research, Arlington, VA, p V50-V59

Croll NA (1972a) Energy utilization of infective Ancylostoma tubaeforme larvae. Parasitology 64:355-368

Croll NA (1972b) Feeding and lipid synthesis of Ancylostoma tubaeforme preinfective larvae. Parasitology 64:369-378

Cuzin-Roudy J, Amsler MO (1991) Ovarian development and sexual maturity staging in Antarctic krill, Euphausia superba Dana (Euphausiacea). J Crust Biol 11:236-249

Cuzin-Roudy J, Buchholz F (1999) Ovarian development and spawning in relation to the moult cycle in Northern krill, Meganyctiphanes norvegica (Crustacea: Euphausiacea), along a climatic gradient. Mar Biol 133:267-281

Cuzin-Roudy J, Albessard E, Virtue P, Mayzaud P (1999) The scheduling of spawning with the moult cycle in Northern krill (Crustacea: Euphausiacea): a strategy for allocating lipids to reproduction. Invertebr Reprod Dev 36:163-170

Dagg M (1977) Some effects of patchy food environments on copepods. Limnol Oceanogr 22:99-107

Dalsgaard J, St. John M, Kattner G, Müller-Navarra D, Hagen W (2003) Fatty acid trophic markers in the pelagic marine environment. Adv Mar Biol 46:225-340

Daly KL (1990) Overwintering development, growth, and feeding of larval Euphausia superba in the Antarctic marginal ice zone. Limnol Oceanogr 35:1564-1576

Dawson JK (1978) Vertical distribution of Calanus hyperboreus in the central Arctic Ocean. Limnol Oceanogr 23:950-957

deChaffoy D, Kondo M (1980) Lipovitellin from the crustacean, Artemia salina. J Biol Chem 255:6727-6732

Defaye D, Such J, Dussart B (1985) The alimentary canal of a freshwater Copepoda, Macrocyclops albicus, and some other Cyclopoida. Acta Zool 66:119-125

Deibel D, Cavaletto JF, Riehl, Gardner WS (1992) Lipid and lipid class content of the pelagic tunicate Oikopleura vanhoeffeni. Mar Ecol Prog Ser 88:297-302

Diel S, Tande K (1992) Does the spawning of Calanus finmarchicus in high latitudes follow a reproducible pattern? Mar Biol 113:21-31

Dolphin PJ (1985) Lipoprotein metabolism and the role of apolipoproteins as metabolic programmers. Can J Biochem Cell Biol 63:850-869
Evanson M, Bornhold EA, Goldblatt RH, Harrison PJ, Lewis AG (2000) Temporal variation in body composition and lipid storage of the overwintering, subarctic copepod Neocalanus plumchrus in the Strait of Georgia, British Columbia (Canada). Mar Ecol Prog Ser 192:239-247

Falk-Petersen S (1981) Ecological investigations on the zooplankton community of Balsjorden, northern Norway: Seasonal changes in body weight and the main biochemical composition of Thysanoessa inermis (Krøyer), T. raschii (M. Sars) and Meganyctiphanes norvegica (M. Sars) in relation to environmental factors. J Exp Mar Biol Ecol 49: 103-120

Falk-Petersen S, Gatten RR, Sargent JR, Hopkins CCE (1981) Ecological investigation on the zooplankton community in Balsfjorden, northern Norway: Seasonal changes in the lipid class composition of Meganyctiphanes norvegia (M. Sars), Thysanoessa raschii (M. Sars), T. inermis (Krøyer). J Exp Mar Biol Ecol 54:209-224

Falk-Petersen S, Sargent JR, Hopkins CCE, Vaja B (1982) Ecological investigations on the zooplankton community of Balsfjorden, northern Norway: lipids in the euphausiids Thysanoessa raschii and T. inermis during the spring. Mar Biol 68:97-102

Falk-Petersen S, Hopkins CCE, Sargent JR (1990) Trophic relationships in the pelagic arctic food web. In: Barnes $M$, Gibson RN (eds) Trophic relationships in the marine environment. Proc 24th Eur Mar Biol Symp. Aberdeen University Press, Aberdeen, p 315-333

Falk-Petersen S, Sargent JR, Lønne OJ, Timofeev S (1999) Functional biodiversity of lipids in Antarctic zooplankton: Calanoides acutus, Calanus propinquus, Thysanoessa macrura and Euphausia crystallorophias. Polar Biol 21: 32-47

Falk-Petersen S, Hagen W, Kattner G, Clarke A, Sargent J (2000) Lipids, trophic relationships, and biodiversity in Arctic and Antarctic krill. Can J Fish Aquat Sci 57: 178-191

Falk-Petersen S, Sargent JR, Kwasniewski S, Gulliksen B, Millar R-M (2001) Lipids and fatty acids in Clione limacina and Limacina helicina in Svalbard waters and the Arctic Ocean: trophic implications. Polar Biol 24:163-170

Falk-Petersen S, Dahl TM, Scott CL, Sargent JR, Gulliksen B, Kwasniewski S, Hop H, Millar RM (2002) Lipid biomarkers and trophic linkages between ctenophores and copepods in Svalbard waters. Mar Ecol Prog Ser 227:187-194

Feigenbaum DL (1991) Food and feeding behavior. In: Bone Q, Knapp H, Pierrot-Bults AC (eds) The biology of the chaetognaths. Oxford Science, New York, p 45

Feigenbaum DL, Maris RC (1984) Feeding in the Chaetognatha. Oceanogr Mar Biol Ann Rev 22:342-392

Fernandez F (1979) Nutrition studies in the nauplius larva of Calanus pacificus (Copepoda:Calanoida). Mar Biol 53: 131-147

Fevolden SE (1980) Krill off Bouvetoya and in the southern Weddell Sea with a description of larval stages of Euphausia crystallorophias. Sarsia 65:149-162

Fleminger A (1957) New calanoid copepods of Pontella Dana and Labidocera Lubbock with notes on the distribution of the genera in the Gulf of Mexico. Tulane Stud Zool 5: 19-34

Folch JM, Lees M, Sloane-Stanley GH (1957) A simple method for the isolation and purification of total lipides from animal tissues. J Biol Chem 226:497-509

Fraser AJ, Tocher DR, Sargent JR (1985) Thin-layer chromatography - flame ionization detection and the quantification of marine neutral lipids and phospholipids. J Exp Mar Biol Ecol 88:91-100 
Fraser AJ, Sargent JR, Gamble JC (1989) Lipid class and fatty acid composition of Calanus finmarchicus (Gunnerus), Pseudocalanus sp. and Temora longicornis Muller from a nutrient-enriched seawater enclosure. J Exp Mar Biol Ecol 130:81-92

Fulton J (1973) Some aspects of the life history of Calanus plumchrus in the Strait of Georgia. J Fish Res Bd Can 30: 811-815

Gallager SM, Mann R (1981) The use of lipid specific staining to monitor condition in bivalve larvae in large scale cultures. J Shellfish Res 1:69-73

Gallager SM, Mann R (1986) Individual variability in lipid content of bivalve larvae quantified histochemically by absorption photometry. J Plankton Res 8:927-937

Gannefors C, Böer M, Kattner G, Graeve M, Eiane K, Gulliksen B, Hop H, Falk-Petersen S (2005) The Arctic sea butterfly Limacina helicina; lipids and life strategy. Mar Biol 147:169-177

Gardner WS, Paffenhöfer GA (1982) Nitrogen regeneration by the subtropical marine copepod Eucalanus pileatus. J Plankton Res 4:725-734

Gatten RR, Corner EDS, Kilvington CC, Sargent JR (1979) A seasonal survey of the lipids of Calanus helgolandicus Claus from the English channel. In: Naylor E, Hartnoll RG (eds) Cyclic phenomena in plants and animals. Pergamon, Oxford, p 275-284

Gatten RR, Sargent JR, Forsberg TEV, O'Hara SCM, Corner EDS (1980) On the nutrition and metabolism of zooplankton. XIV. Utilization of wax esters by Calanus helgolandicus during maturation and reproduction. J Mar Biol Assoc UK 60:391-399

Gislason A, Astthorsson OS, Petursdottir H (2000) Life cycle of Calanus finmarchicus south of Iceland in relation to hydrography and chlorophyll a. ICES J Mar Sci 57:1619-1627

Goulden CE, Hornig LL (1980) Population oscillations and energy reserves in planktonic cladocera and their consequences to competition. Proc Natl Acad Sci USA 77: 1716-1720

Graeve M (1993) Umsatz und Verteilung von Lipiden in arktischen marinen Organismen unter besonderer Berücksichtigung unterer trophischer Stufen. Reports on Polar Research 124:1-141

Graeve M, Kattner G (1992) Species-specific differences in intact wax esters of Calanus hyperboreus and C. finmarchicus from Fram Strait_-Greenland Sea. Mar Chem 39: 269-281

Graeve M, Hagen W, Kattner G (1994a) Herbivorous or ominivorous? On the significance of lipid compositions as trophic markers in Antarctic copepods. Deep-Sea Res 41: 915-924

Graeve M, Kattner G, Hagen W (1994b) Diet-induced changes in the fatty acid composition of Arctic herbivorous copepods: experimental evidence of trophic markers. J Exp Mar Biol Ecol 182:97-110

Graeve M, Albers C, Kattner G (2005) Assimilation and biosynthesis of lipids in Arctic Calanus species based on feeding experiments with a ${ }^{13} \mathrm{C}$ labelled diatom. J Exp Mar Biol Ecol 317:109-125

Greenberg AS, Egan JJ, Wek SA Garty NB, BainchetteMackie EJ, Londos C (1991) Perlipin, a major hormonally regulated adipocyte-specific phosphoprotein associated with the periphery of lipid storage droplets. J Biol Chem 266:11341-11346

Grice GC, Marcus NH (1981) Dormant eggs of marine copepods. Oceanogr Mar Biol Annu Rev 19:125-140

Hadley NF (1985) The adaptive role of lipids in biological systems. Wiley, New York
Hagen W (1988) On the significance of lipids in Antarctic zooplankton. Ber Polarforsch 49:1-129 \{English version: Can Transl Fish Aquat Sci 5458(1989):1-149]

Hagen W (1999) Reproductive strategies and energetic adaptations of polar zooplankton. Invertebr Reprod Dev 36: $25-34$

Hagen W (2000) Lipids. In: Harris R, Wiebe P, Lenz J, Skjoldal HR, Huntley M (eds) ICES zooplankton methodology manual, Academic, San Diego, CA, p 113-119

Hagen W, Auel H (2001) Seasonal adaptations and the role of lipids in oceanic zooplankton. Zoology 104:313-326

Hagen W, Kattner G (1998) Lipid metabolism of the Antarctic euphausiid Thysanoessa macrura and its ecological implications. Limnol Oceanogr 43:1894-1901

Hagen W, Schnack-Schiel SB (1996) Seasonal lipid dynamics in dominant Antarctic copepods: energy for overwintering or reproduction? Deep-Sea Res 43:139-158

Hagen W, Kattner G, Graeve M (1993) Calanoides acutus and Calanus propinquus, Antarctic copepods with different lipid storage modes via wax esters or triacylglycerols. Mar Ecol Prog Ser 97:135-142

Hagen W, Kattner G, Graeve M (1995) On the lipid biochemistry of polar copepods: Compositional differences in the Antarctic calanoids Euchaeta antarctica and Euchirella rostromagna. Mar Biol 123:451-457

Hagen W, Van Vleet ES, Kattner G (1996) Seasonal lipid storage as overwintering strategy of Antarctic krill. Mar Ecol Prog Ser 134:85-89

Hagen W, Kattner G, Terbrüggen A,Van Vleet ES (2001) Lipid metabolism of the Antarctic krill Euphausia superba and its ecological implications. Mar Biol 139:95-104

Håkanson JL (1984) The long and short term feeding condition in field-caught Calanus pacificus, as determined from the lipid content. Limnol Oceanogr 29:794-804

Håkanson JL (1987) The feeding condition of Calanus pacificus and other zooplankton in relation to phytoplankton pigments in the California Current. Limnol Oceanogr 32: 881-894

Hallberg E, Hirche HJ (1980) Differentiation of mid-gut in adults and over-wintering copepodids of Calanus finmarchicus (Gunnerus) and C. helgolandicus Claus. J Exp Mar Biol Ecol 48:283-293

Harrington GW, Beach DH, Dunham JE, Holz GG (1970) The polyunsaturated fatty acids of dinoflagellates. J Protozool $17: 213-219$

Harris RP, Berdugo V, Corner EDS, Kilvington CC, O'Hara SCM (1977) Factors affecting the retention of a petroleum hydrocarbon by marine planktonic copepods. In: Wolfe DA (ed) Fate and effects of petroleum hydrocarbons in marine ecosystems and organisms. Pergamon, Oxford, p 286-304

Hassett RP, Landry MR (1990) Effects of diet and starvation on digestive enzyme activity and feeding behavior of the marine copepod Calanus pacificus. J Plankton Res 12: 991-1010

Havel R (1987) Lipid transport function of lipoproteins in blood plasma. Am J Physiol 253:E1-E5

Head EJH, Harris LF (1985) Physiological and biochemical changes in Calanus hyperboreus from Jones Sound NWT during the transition from summer feeding to overwintering condition. Polar Biol 4:99-106

Heath MR (1999) The ascent migration of Calanus finmarchicus from overwintering depths in the Faroe-Shetland Channel. Fish Oceanogr 8:84-99

Heath MR, Jónasdóttir SH (1999) Distribution and abundance of overwintering Calanus finmarchicus in the FaroeShetland Channel. Fish Oceanogr 8:61-71 
Heinle DR (1981) Zooplankton. In: Vernberg FI, Vernberg WB (eds) Functional adaptations of marine organisms. Academic, New York, p 85-145

Henderson RJ, Sargent JR (1980) Biosynthesis of neutral lipids by Euchaeta norvegica. Mar Biol 56:1-6

Henderson RJ, Sargent JR, Falk-Petersen S (1981) Lipogenesis in the Arctic euphausiid Thysanoessa inermis. Mar Biol 63:235-240

Hentschel BT (1998) Spectrofluorometric quantification of neutral and polar lipids suggests a food-related recruitment bottleneck for juveniles of a deposit-feeding polychaete population. Limnol Oceanogr 43:543-549

Herring PJ (1973) Depth distribution of the carotenoid pigments and lipids of some oceanic animals. 2. Decapod crustaceans. J Mar Biol Assoc UK 53:539-562

Herring PJ, Morris RJ (1975) Embryonic metabolism of carotenoid pigments and lipid in species of Acanthephyra (Crustacea: Decapoda). In Barnes H (ed) Proc 9th Eur Mar Biol Symp. Aberdeen University Press, Aberdeen, p 299-310

Hilton IF (1931) The oogenesis of Calanus finmarchicus. Q J Micro Sci 74:193-222

Hirche HJ (1989) Egg production of the Arctic copepod Calanus glacialis: laboratory experiments. Mar Biol 103: 311-318

Hirche HJ (1996) The reproductive biology of the marine copepod Calanus finmarchicus - a review. Ophelia 44: 111-128

Hirche HJ (1997) Life cycle of the copepod Calanus hyperboreus in the Greenland Sea. Mar Biol 128:607-618

Hirche HJ, Kattner G (1993) Egg production and lipid content of Calanus glacialis in spring: indication of a food-dependent and food-independent reproductive mode. Mar Biol 117:615-622

Hirche HJ, Niehoff B (1996) Reproduction of the copepod Calanus hyperboreus in the Greeland Sea and laboratory observations. Polar Biol 16:601-612

Hirche HJ, Fetzer I, Graeve M, Kattner G (2003) Limnocalanus macrurus in the Kara Sea (Arctic Ocean): an opportunistic copepod as evident from distribution and lipid patterns. Polar Biol 26:720-726

Hoeger U (1983) Biochemical composition of ctenophores. J Exp Mar Biol Ecol 72:251-261

Holland DL, Hannant PJ (1974) Biochemical changes during growth of the spat of the oyster, Ostrea edulis L. J Mar Biol Assoc UK 54:1007-1016

Holland DL, Spencer BE (1973) Biochemical changes in fed and starved oysters, Ostrea edulis L. during larval development, metamorphosis and early spat growth. J Mar Biol Assoc UK 53:287-298

Holland DL, Walker G (1975) The biochemical composition of the cypris larva of the barnacle Balanus balanoides (L.). J Cons Int Explor Mer 36:162-165

Holtz RB, Marques ED, Benson AA (1973) Wax ester biosynthesis by isolated membrane fractions from calanoid copepods. Comp Biochem Physiol 45B:585-591

Hopkins CCE (1977) The relationship between maternal body size and clutch size, development time and egg mortality in Euchaeta norvegica (Copepoda: Calanoida) from Loch Etive, Scotland. J Mar Biol Assoc UK 57:723-733

Hopkins CCE, Pettersen F, Evans RA, Greenlaw CF (1982) Zoooplankton sound scattering layers in north Norwegian fjords: specifications and function of the acoustical, dataand net-sampling systems. Sarsia 67:187-199

Houde S, Roman MR (1987) Effects of food quality on the functional ingestion response of the copepod Acartia tonsa. Mar Ecol Prog Ser 40:69-77
Hygum BH, Rey C, Hansen BW (2000a) Growth and development rates of Calanus finmarchicus nauplii during a diatom spring bloom. Mar Biol 136:1075-1085

Hygum BH, Rey C, Hansen BW, Carlotti F (2000b) Rearing cohorts of Calanus finmarchicus (Gunnerus) in mesocosms. J Mar Sci 57:1740-1751

Hygum BH, Rey C, Hansen BW, Tande K (2000c) Importance of food quantity to structural growth rate and neutral lipid reserves accumulated in Calanus finmarchicus. Mar Biol 136:1057-1073

Ianora A, Santella L (1991) Diapause embryos in the neustonic copepod Anomalocera patersoni. Mar Biol 108: $387-394$

Ikeda T (1972) Chemical composition and nutrition of zooplankton in the Bering Sea. In: Takenouti AY (ed) Biological oceanography of the northern North Pacific Ocean. Idemitsu Shoten, Tokyo, p 433-442

Ikeda T (1974) Nutritional ecology of marine zooplankton. Mem Fac Fish Hokkaido Univ 22:1-97

Ikeda T (1984) Development of the larvae of the Antarctic krill (Euphausia superba Dana) observed in the laboratory. J Exp Mar Biol Ecol 75:107-117

Ikeda T, Dixon P (1982) Observations on moulting in Antarctic krill (Euphausia superba). Aust J Mar Freshw Res 33: $71-76$

Irigoien X (2004) Some ideas about the role of lipids in the life cycle of Calanus finmarchicus. J Plankton Res 26:259-263

Jillett JB (1968) Calanus tonsus (Copepoda, Calanoida) in southern New Zealand waters with notes on the male. Aust J Mar Freshw Res 19:19-30

Jónasdóttir SH (1999) Lipid content of Calanus finmarchicus during overwintering in the Faroe-Shetland Channel. Fish Oceanogr 8(Suppl 1):61-72

Jónasdóttir SH, Gudfinnsson HG, Gislason A, Astthorsson OS (2002) Diet composition and quality for Calanus finmarchicus egg production and hatching success off southwest Iceland. Mar Biol 140:1195-1206

Ju S-J, Scolardi K, Daly KL, Harvey HR (2004) Understanding the trophic role of the Antarctic ctenophore, Callianira antarctica, using lipid biomarkers. Polar Biol 27:782-792

Kanost MR, Kawooya JK, Law JH, Ryan RO, Van Heuden MC, Ziegler R (1990) Insect haemolymph proteins. Adv Insect Physiol 22:299-396

Kates K, Volcani BE (1966) Lipid components of diatoms. Biochim Biophys Acta 116:264-278

Kattner G (1989) Lipid composition of Calanus finmarchicus from the North Sea and the Arctic. A comparative study. Comp Biochem Physiol 94B:185-188

Kattner G (1991) Marine Lipide nördlicher Meeresgebiete unter besonderer Berücksichtigung der calanoiden Copepoden. Habil thesis, University of Bremen

Kattner G, Fricke HSG (1986) Simple gas-liquid chromatographic method for the simultaneous determination of fatty acids and alcohols in wax esters of marine organisms. J Chromatogr 361:263-268

Kattner G, Hagen W (1998) Lipid metabolism of the Antarctic euphausiid Euphausia crystallorophias and its ecological implications. Mar Ecol Prog Ser 170:203-213

Kattner G, Krause M (1987) Changes in lipids during the development of Calanus finmarchicus s.l. from copepodid I to adult. Mar Biol 96:511-518

Kattner G, Krause M (1989) Seasonal variations of lipids (wax esters, fatty acids and alcohols) in calanoid copepods from the North Sea. Mar Chem 26:261-275

Kattner G, Krause M, Trahms J (1981) Lipid composition of some typical North Sea copepods. Mar Ecol Prog Ser 4: 69-74 
Kattner G, Graeve M, Ernst W (1990) Gas-liquid chromatographic method for the determination of marine wax esters according to the degree of unsaturation. J Chromatogr 513:327-332

Kattner G, Graeve M, Hagen W (1994a) Ontogenetic and seasonal changes in lipid and fatty acid/alcohol compositions of the dominant Antarctic copepods Calanus propinquus, Calanoides acutus and Rhincalanus gigas. Mar Biol 118: 637-644

Kattner G, Werthmann IS, Merck T (1994b) Interannual variations of lipids and fatty acids during larval development of Crangon spp. in the German Bight, North Sea. Comp Biochem Physiol 107B:103-110

Kattner G, Hagen W, Falk-Petersen S, Sargent JR, Henderson RJ (1996) Antarctic krill Thysanoessa macrura fills a major gap in marine lipogenic pathways. Mar Ecol Prog Ser 134: 295-298

Kattner G, Hagen W, Graeve M, Albers C (1998) Exceptional lipids and fatty acids in the pteropod Clione limacina (Gastropoda) from both polar oceans. Mar Chem 61: 219-228

Kattner G, Graeve M, Calcagno JA, Lovrich GA, Thatje S, Anger K (2003) Lipid, fatty acid and protein utilization during lecithotrophic larval development of Lithodes santolla (Molina) and Paralomis granulosa (Jacquinot). J Exp Mar Biol Ecol 292:61-74

Kayama M (1982) Distribution and function of wax in marine ecosystem. Mar Sci 14:26-38

Kayama M, Mankura M (1980) Hydrolysis and synthesis of wax ester by calanoid copepod, Acartia clausi, preparation. Bull Jap Soc Sci Fish 46:1501-1505

Klein Breteler WCM, Gonzalez SR (1988) Influence of temperature and food concentration on body size, weight and lipid content of two calanoid copepod species. Hydrobiol 167/168:201-210

Kobari T, Ikeda T (1999) Vertical distribution, population structure and life cycle of Neocalanus cristatus (Crustacea: Copepoda) in the Oyashio region, with notes on its regional variations. Mar Biol 134:683-696

Køgeler JW, Falk-Petersen S, Kristensen A, Pettersen F, Dalen J (1987) Density- and sound speed contrasts in sub-arctic zooplankton. Polar Biol 7:231-235

Kosobokova KN (1990) Age-related and seasonal changes in the biochemical make-up of the copepod Calanus glacialis as related to the characteristics of its life cycle in the White Sea. Oceanology 30:103-109

Kremer P, Reeve MR (1989) Growth dynamics of a ctenophore (Mnemiopsis) in relation to variable food supply. II. Carbon budgets and growth model. J Plankton Res 11: 553-574

Laabir M, Buttino I, Ianora A, Kattner G, Poulet SA, Romano G, Carotenuto Y, Miralto A (2001) Effect of specific dinoflagellate and diatom diets on gamete ultrastructure and fatty acid profiles of the copepod Temora stylifera. Mar Biol 138:1241-1250

Landry MR (1983) The development of marine calanoid copepods with comment on the isochronal rule. Limnol Oceanog 28:614-624

Larson RJ, Harbison GR (1989) Source and fate of lipids in polar gelatinous zooplankton. Arctic 42:339-346

Lee RF (1974a) Lipids of zooplankton from Bute Inlet, British Columbia. J Fish Res Bd Can 31:1577-1582

Lee RF (1974b) Lipid composition of the copepod Calanus hyperboreus from the Arctic Ocean. Changes with depth and season. Mar Biol 26:313-318

Lee RF (1975) Lipids of Arctic zooplankton. Comp Biochem Physiol 51B:263-266
Lee RF (1991) Lipoproteins from the hemolymph and ovaries of marine invertebrates. In: Gilles R (ed) Advances in comparative and environmental physiology, Vol 7. Springer, Berlin, p 187-207

Lee RF, Barnes AT (1975) Lipids in the mesopelagic copepod, Gaussia princeps. Wax ester utilization during starvation. Comp Biochem Physiol 52B:265-268

Lee RF, Hirota J (1973) Wax esters in tropical zooplankton and nekton and the geographical distribution of wax esters in marine copepods. Limnol Oceanogr 18:227-239

Lee RF, Nevenzel JC (1979) Wax esters in the marine environment: origin and composition of the wax from the Bute Inlet, British Columbia. J Fish Res Bd Can 36:1519-1523

Lee RF, Puppione DL (1988) Lipoproteins I and II from the hemolymph of the blue crab Callinectes sapidus: Lipoprotein II associated with vitellogenesis. J Exp Zool 248: 278-289

Lee RF, Walker A (1995) Lipovitellin and lipid droplet accumulation in oocytes during ovarian maturation in the blue crab, Callinectes sapidus. J Exp Zool 272:401-412

Lee RF, Nevenzel JC, Paffenhöfer GA (1970) Wax esters in marine copepods. Science 167:1510-1511

Lee RF, Hirota J, Barnett AM (1971a) Distribution and importance of wax esters in marine copepods and other zooplankton. Deep-Sea Res 18:1147-1165

Lee RF, Nevenzel JC, Paffenhöfer GA (1971b) Importance of wax esters and other lipids in the marine food chain: phytoplankton and copepods. Mar Biol 9:99-108

Lee RF, Nevenzel JC, Paffenhöfer (1972) The presence of wax esters in marine planktonic copepods. Naturwissenschaften 59:406-411

Lee RF, Nevenzel JC, Lewis AG (1974) Lipid changes during life cycle of marine copepod Euchaeta japonica Marukawa. Lipids 9:891-898

Lindley JA (1990) Distribution of overwintering calanoid copepod eggs in sea-bed sediments around southern Britain. Mar Biol 104:209-217

Littlepage JL (1964) Seasonal variation in lipid content of two Antarctic marine crustacean. In: Carrick R, Holdgate M, Prevost J (eds) Biologie antarctique. Hermann, Paris, p 463-470

Locke A, Sprules WG (1993) Effects of experimental acidification on zooplankton population and community dynamics. Can J Fish Aquat Sci 50:1238-1247

Loeb V, Siegel V, Holm-Hansen O, Hewitt R, Fraser W, Trivelpiece W, Trivelpiece S (1997) Effects of sea-ice extent and krill or salp dominance on the Antarctic food web. Nature 387:897-900

Longhurst AR (1967) Vertical distribution of zooplankton in relation to the eastern Pacific oxygen minimum. Deep-Sea Res 14:51-61

Longhurst AR (1998) Ecological geography of the sea. Academic, San Diego, CA

Lovern JA (1935) Fat metabolism in fishes. VI. The fats of some plankton crustacea. Biochem J 29:847-849

Lucas MI, Walker G, Holland DL, Crisp DJ (1979) An energy budget for the free-swimming and metamorphosing larvae of Balanus balanoides (Crustacea: Cirripedia). Mar Biol 55:221-229

Lundberg M (2003) Mertensia ovum (Ctenophora) in Kongsfjorden, Svalbard - life strategy aspects. MS Thesis, University of Tromsø

Mackas DL (1992) Seasonal cycle of zooplankton off southwestern British Columbia: 1979-89. Can J Fish Aquat Sci 49:903-921

Mackas DL, Tsuda A (1999) Mesozooplankton in the eastern and western subarctic Pacific: community structure, sea- 
sonal life histories, and interannual variability. Prog Oceanogr 43:335-363

Madin LP, Cetta CM, McAlister VL (1981) Elemental and biochemical composition of salps (Tunicata:Thaliacea). Mar Biol 63:217-226

Marcus NH (1989) Abundance in bottom sediments and hatching requirements of eggs of Centropages hamatus (Copepoda:Calanoida) from the Alligator Harbor Region, Florida. Biol Bull 176:142-146

Marcus NH (1996) Ecological and evolutionary significance of resting eggs in marine copepods: past, present, and future studies. Hydrobiology 320:141-152

Marcus NH, Fuller CM (1989) Distribution and abundance of eggs of Labidocera aestiva (Copepoda: Calanoida) in the bottom sediments of Buzzards Bay, Massachusetts, USA. Mar Biol 100:319-326

Marker T, Andreassen P, Arashkewich, Hansen BW (2003) Lipid deposition and sexual maturation in cohorts of Calanus finmarchicus (Gunnerus) originating from Bergen $\left(60^{\circ} \mathrm{N}\right)$ and Troms $\varnothing\left(69^{\circ} \mathrm{N}\right)$ reared in Troms $\varnothing$, Norway. Mar Biol 143:283-296

Marr JEW (1962) The natural history and geography of the Antarctic krill (Euphausia superba Dana). Discovery Rep 32:33-464

Marshall SM, Orr AP (1972) The biology of a marine copepod. Springer, Berlin

Marshall SM, Nicholls AG, Orr AP (1934) On the biology of Calanus finmarchicus. V. Seasonal distribution, size, weight and chemical composition in Loch Striven in 1933, and their relation to the phytoplankton. J Mar Biol Assoc UK 19:793-827

Matsuo Y, Marumo R (1982) Diurnal vertical migration of Pontellid copepods in the Kuroshio. Bull Plankton Soc 29: 89-98

Mayzaud P (1976) The occurrence and distribution of octadecapentaenoic acid in a natural plankton population. A possible food chain index. Lipids 11:858-862

Mayzaud P (1997) Spatial and life-cycle changes in lipid and fatty acid structure of the Antarctic euphausiid Euphausia superba. In: Battaglia B, Valencia J, Walton DWH (eds) Antarctic Communities: species, structure and survival. Proc 6th SCAR Symp on Antarctic Biology, Cambridge University Press, Cambridge, p 284-294

McLaren IA, Corkett CJ (1984) Single, mass-specific P/B ratios cannot be used to estimate copepod production. Can J Fish Aquat Sci 41:829-830

Mensah MA (1974) The reproduction and feeding of the marine copepod Calanoides carinatus (Krøyer) in Ghanaian waters. Ghana J Sci 14:167-191

Meyer B, Atkinson A, Stübing D, Hagen W, Bathmann UV (2002) Feeding and energy budgets of Antarctic krill Euphausia superba at the onset of winter I. Furcilia III larvae. Limnol Oceanogr 47:943-952

Miller CB (1983) The zooplankton of estuaries. In: Ketchum $\mathrm{BH}$ (ed) Estuaries and enclosed seas. Elsevier, Amsterdam, p 103-149

Miller CB, Nielsen RD (1988) Development and growth of large, calanid copepods in the ocean subarctic Pacific, May, 1984. Prog Oceanogr 20:275-292

Miller CB, Frost BW, Batchelder HP, Clemons MJ, Conway RE (1984) Life histories of large, grazing copepods in a subarctic ocean gyre: Neocalanus plumchrus, Neocalanus cristatus, and Eucalanus bungii in the northeast Pacific. Prog Oceanogr 13:201-243

Miller CB, Morgan CA, Prahl FG, Sparrow MA (1998) Storage lipids of the copepod Calanus finmarchicus from Georges Bank and the Gulf of Maine. Limnol Oceanogr 43:488-497
Minoda T (1971) Pelagic Copepoda in the Bering Sea and the north-western North Pacific with special reference to their vertical distribution. Mem Fac Fish Hokkaido Univ 18: $1-74$

Morris MJ, Hopkins TL (1983) Biochemical composition of crustacean zooplankton from the eastern Gulf of Mexico. J Exp Mar Biol Ecol 69:1-19

Nakai Z (1955) The chemical composition, volume, weight, and size of the important marine plankton. Tokai Reg Fish Res Lab Spec Publ 5:12-24

Nakai Z (1969) Notes on mature female, floating egg and nauplius of Calanus cristatus Krøyer (Crustacea, Copepoda). Bull Jpn Soc Fish Oceanogr (Spec. Issue):183-191

Nelson MM, Phleger CF, Mooney BD, Nichols PD (2000) Lipids of gelatinous Antarctic zooplankton: Cnidaria and Ctenophora. Lipids 35:551-559

Nicol S, de la Mare WK, Stolp M (1995) The energetic cost of egg production in Antarctic krill (Euphausia superba Dana). Antarct Sci 7:25-30

Niehoff B (2004) The effect of food limitation on gonad development and egg production of the planktonic copepod Calanus finmarchicus. J Exp Mar Biol Ecol 307:237-259

Nielsen TG, Hansen B (1995) Plankton community structure and carbon cycling on the western coast of Greenland during and after the sedimentation of a diatom bloom. Mar Ecol Prog Ser 125:239-257

Nival P, Malara G, Charra R, Palazzoli, Nival S (1974) Etude de la respiration et de l'excretion de quelques copepodes planctonqiues (Crustacea) dans la zone de remontee d'eau profonde des cotes marocaines. J Exp Mar Biol Ecol 15: 231-260

Nival S, Pagano M, Nival P (1990) Laboratory study of the spawning rate of the calanoid copepod Centropages typicus: effect of fluctuating food concentration. J Plankton Res 12:535-547

Nordbäck J, Lundberg E (1999) High resolution separation of non-polar lipid classes by HPLC-ELSD using alumina as stationary phase. J High Resol Chromatogr 22:483-486

Norrbin ME, Olsen RE, Tande KS (1990) Seasonal variation in lipid class and fatty acid composition of two small copepods in Balsfjorden, northern Norway. Mar Biol 105:205-211

Ohman MD (1987) Energy sources for recruitment of the subantarctic copepod Neocalanus tonsus. Limnol Oceanogr 32:1317-1330.

Ohman MD (1988) Sources of variability in measurements of copepod lipids and gut fluorescence in the California Current coastal zone. Mar Ecol Prog Ser 42:143-153

Ohman MD, Runge JA (1994) Sustained fecundity when phytoplankton resources are in short supply: omnivory by Calanus finmarchicus in the Gulf of St. Lawrence. Limnol Oceanogr 39:21-36

Ohman MD, Bradford JM, Jillett JB (1989) Seasonal growth and lipid storage of the circumglobal, subantarctic copepod, Neocalanus tonsus. Deep-Sea Res 36:1309-1326

Ohman MD, Drits AV, Clarke ME, Plourde S (1998) Differential dormancy of co-occurring copepods. Deep-Sea Res II 45:1709-1740

Olsen RE, Henderson RJ (1989) The rapid analysis of neutral and polar marine lipids using double-development HPTLC and scanning densitometry. J Exp Mar Biol Ecol 129:189-197

Osgood KE, Frost BW (1994) Comparative life histories of three species of planktonic calanoid copepods in Dabob Bay, Washington. Mar Biol 118:627-636

Østvedt OJ (1955) Zooplankton investigations from Weathership M in the Norwegian Sea 1948-1949. Hvalrådets Skr $4: 1-93$ 
Paffenhöfer GA, Harris RP (1976) Feeding, growth and reproduction of the marine planktonic copepod Pseudocalanus elongatus Boeck. J Mar Biol Assoc UK 56:327-344

Parrish CC (1987) Separation of aquatic lipid classes by Chromarod thin-layer chromatography with measurement by Iatroscan flame ionization detection. Can J Fish Aquat Sci 44:722-731

Parrish CC (1999) Determination of total lipid, lipid classes, and fatty acids in aquatic samples. In: Arts MT, Wainman BC (eds) Lipids in freshwater ecosystems. Springer, New York, p 4-20

Parrish CC, Ackman RG (1983) Chromarod separations for the analysis of marine lipid classes by Iatroscan thin-layer chromatography flame ionization detection. J Chromatogr 262:103-112

Parrish CC, Ackman RG (1985) Calibration of the IatroscanChromarod system for marine lipid class analyses. Lipids 20:521-530

Pasternak A, Arashkevich E, Tande K, Falkenhaug T (2001) Seasonal changes in feeding, gonad development and lipid stores in Calanus finmarchicus and C. hyperboreus from Malangen, northern Norway. Mar Biol 138: 1141-1152

Pasternak A, Riser CW, Arashkevich E, Rat'kova T, Wassmann P (2002) Calanus spp. grazing affects egg production and vertical carbon flux (the marginal ice zone and open Barents Sea). J Mar Syst 38:147-164

Pedersen G, Tande KS, Nilssen EM (1995) Temporal and regional variation in the copepod community in the central Barents Sea during spring and early summer 1988 and 1989. J Plankton Res 17:263-282

Peterson WT (1986) Development, growth, and survivorship of the copepod Calanus marshallae in the laboratory. Mar Ecol Prog Ser 29:61-72

Petipa TS (1964a) The diural rhythm in feeding and daily ratio of Calanus helgolandicus (Claus) in the Black Sea. Tr Sevastop Biol Stn 15:69-93 (translation N.S. 71, Min Agr Fish Food, UK)

Petipa TS (1964b) Fat metabolism of Calanus helgolandicus (Claus) under experimental condition. Dokl Acad Sci USSR Biol Sci 155:314-318

Phleger CF, Nichols PD, Virtue P (1997) Lipids and buoyancy in Southern Ocean pteropods. Lipids 32:1093-1100

Phleger CF, Nichols PD, Virtue P (1998) Lipids and trophodynamics of Antarctic zooplankton. Comp Biochem Physiol 120B:311-323

Picaud JL (1980) Vitellogenin synthesis by the fat body of Porcellio dilatus Brandt (Crustacea, Isopoda). Int J Invertebr Reprod 2:341-349

Pond D, Watkins J, Priddle J, Sargent J (1995) Variation in the lipid content and composition of Antarctic krill Euphausia superba at South Georgia. Mar Ecol Prog Ser 117:49-57

Quetin LB, Ross RM (2001) Environmental variability and its impact on the reproductive cycle of Antarctic krill. Am Zool 41:74-89

Ratnayake WN, Ackman RG (1979a) Fatty alcohols in capelin, herring and mackerel oils and muscle lipids: I. Fatty alcohols details linking dietary copepod fat with certain fish depot fats. Lipids 14:795-803

Ratnayake WN, Ackman RG (1979b) Fatty alcohols in capelin, herring and mackerel oils and muscle lipids: II. A comparison of fatty acids from wax esters with those of triglycerides. Lipids 14:804-810

Raymont JEG, Krishnaswamy S, Woodhouse MA, Griffin RL (1974) Studies on the fine structure of Copepoda. Observations on Calanus finmarchicus (Gunnerus). Proc R Soc Lond 185B:409-424
Reeve MR, Raymont JEG, Raymont JKB (1970) Seasonal biochemical composition and energy sources of Sagitta hispida. Mar Biol 6:357-364

Reiss CS, McLaren IA, Avendaño PA (1999) Utility of storage lipid volumes in inferring recent trophic history of copepods. Can J Fish Aquat Sci 56:2444-2449

Richardson K, Jónasdóttir SH, Hay SJ, Christoffersen A (1999) Calanus finmarchicus egg production and food availability in the Faroe-Shetland Channel and northern North Sea: October-March. Fish Oceanogr 8(Suppl):153-162

Ringuette M, Fortier L, Fortier M, Runge JA, Belanger S, Larouche P, Weslawski JM, Kwasniewski S (2002) Advanced recruitment and accelerated population development in Arctic calanoid copepods of the North Water. Deep-Sea Res II 49:5081-5099

Robinson AG, Dillaman RM (1985) The effects of naphthalene on the ultrastructure of the hepatopancreas of the fiddler crab, Uca minax. J Invertebr Reprod 45:311-323

Ross RM, Quetin LB (1991) Ecological physiology of larval euphausiids, Euphausia superba (Euphausiacea). Mem Queensl Mus 31:321-333

Ross RM, Daly KL, English TS (1982) Reproductive cycle and fecundity of Euphausia pacifica. Limnol Oceanogr 27: 304-314

Runge JA (1984) Egg production of the marine, planktonic copepod, Calanus pacificus. Limnol Oceanogr 25:134-145

Saether O, Ellingsen TE, Mohr V (1983) The distribution of lipid in the tissues of Antarctic krill, Euphausia superba. Comp Biochem Physiol 81B:609-614

Saether O, Ellingsen TE, Mohr V (1986) Lipids of North Atlantic krill. J Lipid Res 27:274-285

Sagrista E, Durfort M (1991) Membranous tubular system in R-cells of decapod hepatopancreas investigated using electron-opaque tracers. Cell Tissue Res 266:585-590

Saito H, Kotani Y (2000) Lipids of four boreal species of calanoid copepods: origin of monoene fats of marine animals at higher trophic levels in the grazing food chain in the subarctic ocean ecosystem. Mar Chem 71:69-82

Saito H, Tsuda A (2000) Egg production and early development of the subarctic copepods Neocalanus cristatus, $N$. plumchrus and $N$. flemingeri. Deep-Sea Res I 47: 2141-2158

Sargent JR, Falk-Petersen SF (1981) Ecological investigations on the zooplankton community in Balsfjorden, northern Norway: Lipids and fatty acids in Meganyctiphanes norvegia, Thysanoessa raschi, and T. inermis during midwinter. Mar Biol 62:131-137

Sargent JR, Henderson RJ (1986) Lipids. In: Corner EDS, O'Hara SCM (eds) The biological chemistry of marine copepods. Clarendon, Oxford, p 59-108

Sargent JR, Lee RF (1975) Biosynthesis of lipids in zooplankton from Saanich Inlet, British Columbia, Canada. Mar Biol 31:15-23

Sargent JR, Gatten RR, McIntosh R (1974) Biosynthesis of wax esters in cell-free preparations of Euchaeta norvegica. Comp Biochem Physiol 47B:217-227

Sargent JR, Gatten RR, Corner EDS, Kilvington CC (1977) On the nutrition and metabolism of zooplankton. XI. Lipids in Calanus helgolandicus grazing Biddulphia sinensis. J Mar Biol Ass UK 57:525-533

Sargent JR, Gatten RR, Henderson RJ (1981) Lipid biochemistry of zooplankton from high latitudes. Oceanis 7: $623-632$

Sargent JF, Eilertsen HC, Falk-Petersen S, Tassen JP (1985) Carbon assimilation and lipid production in phytoplankton in northern Norwegian fjords. Mar Biol 85:109-116

Schnack-Schiel SB, Hagen W (1994) Life cycle strategies and 
seasonal variations in distribution and population structure of four dominant calanoid copepod species in the eastern Weddell Sea, Antarctica. J Plankton Res 16: 1543-1566

Schnack-Schiel SB, Hagen W (1995) Life-cycle strategies of Calanoides acutus, Calanus propinquus and Metridia gerlachei (Copepoda: Calanoida) in the eastern Weddell Sea, Antarctica. ICES J Mar Sci 52:541-548

Schnack-Schiel SB, Hagen W, Mizdalski E (1991) Seasonal comparison of Calanoides acutus and Calanus propinquus (Copepoda: Calanoida) in the southeastern Weddell Sea, Antarctica. Mar Ecol Prog Ser 70:17-27

Schnack-Schiel SB, Thomas D, Dieckmann GS, Eicken H and 5 others (1995) Life cycle strategy of the Antarctic calanoid copepod Stephos longipes. Prog Oceanogr 36:45-75

Scott CL (2000) Calanoid copepods and ice fauna in Arctic fjords and regions of the marginal ice zone around Svalbard: lipids; stage distributions; trophic interactions and life strategies. PhD thesis, University of Stirling

Scott CL, Falk-Petersen S, Sargent JR, Hop H, Lonne OJ, Poltermann M (1999) Lipids and trophic interactions of ice fauna and pelagic zooplankton in the marginal ice zone of the Barents Sea. Polar Biol 21:65-70

Scott CL, Kwasniewski S, Falk-Petersen S, Sargent JR (2000) Lipids and life strategies of Calanus finmarchicus, Calanus glacialis and Calanus hyperboreus in late autumn, Kongsfjorden, Svalbard. Polar Biol 23:510-516

Scott CL, Falk-Petersen S, Gulliksen B, Lønne OJ, Sargent JR (2001) Lipid indicators of the diet of the sympagic amphipod Gammarus wilkitzkii in the Marginal Ice Zone and in open waters of Svalbard (Arctic). Polar Biol 24:572-576

Scott CL, Kwasniewski S, Falk-Petersen S, Sargent JR (2002) Lipids and fatty acids in the copepod Jaschnovia brevis (Jaschnov) and in particulates from Arctic waters. Polar Biol 25:65-71

Slagstad D, Tande KS (1990) Growth and production dynamics of Calanus glacialis in an arctic pelagic food web. Mar Ecol Prog Ser 63:189-199

Smith SL (1984) Biological indications of active upwelling in the northwestern Indian Ocean in 1964 and 1979, and a comparison with Peru and northwest Africa. Deep-Sea Res 31:951-967

Smith SL (1988) Copepods in the Fram Strait in summer: distribution, feeding and metabolism. J Mar Res 46:145-181

Smith SL (1990) Egg production and feeding by copepods prior to the spring bloom of phytoplankton in the Fram Strait area of the Greenland Sea. Mar Biol 106:189-199

Smith SL (2001) Understanding the Arabian Sea: Reflections on the 1994-1996 Arabian Sea expedition. Deep-Sea Res II 48:1385-1402

Smith SL, Vidal J (1986) Variations in the distribution, abundance and development of copepods in the southeastern Bering Sea in 1980 and 1981. Continental Shelf Res 5: 215-239

Sommer U, Berninger UG, Böttger-Schnack R, Cornils A and 8 others (2002) Grazing during early spring in the Gulf of Aqaba and the northern Red Sea. Mar Ecol Prog Ser 239: 251-261

Stübing D (2004) Lipid biochemistry of Antarctic euphausiids - energetic adaptations and a critical appraisal of trophic biomarkers. PhD thesis, University of Bremen

Sullivan BK, McManus LT (1986) Factors controlling seasonal succession of the copepods Acartia hudsonica and A. tonsa in Narragansett Bay, Rhode Island: temperature and resting egg production. Mar Ecol Prog Ser 28: $121-128$

Sun S, Zhang G, Yang B, Li C, Pu X, Zhang Y, Wang X (2002)
Study on the over summer strategy of Calanus sinicus. In: Book of abstracts, 2nd GLOBEC Open Science Meeting. Yellow Sea Fisheries Research Institute, Quingdao, p 145

Swadling KM, Nichols PD, Gibson JAE, Ritz DA (2000) Role of lipid in the life cycles of ice-dependent and ice-independent populations of the copepod Paralabidocera antarctica. Mar Ecol Prog Ser 208:171-182

Tande KS, Henderson RJ (1988) Lipid composition of copepodite stages and adult females of Calanus glacialis in Arctic waters of the Barents Sea. Polar Biol 8:333-339

Tessier AJ, Goulden CE (1982) Estimating food limitation in cladoceran populations. Limnol Oceanogr 27:707-717

Timonin AG, Arashkevich EG, Drits AV, Semenova TN (1992) Zooplankton dynamics in the northern Benguela ecosystem, with special reference to the copepod Calanoides carinatus. S Afr J Mar Sci 12:545-560

Tourangeau S, Runge JA (1991) Reproduction of Calanus glacialis under ice in spring in southeastern Hudson Bay, Canada. Mar Biol 108:227-233

Uchima M, Hirano R (1986) Food of Oithona davisae (Copepoda: Cyclopoida) and the effect of food concentration at first feeding on the larval growth. Bull Plankton Soc Jpn $33: 21-28$

Uye SI (1981) Fecundity studies of neritic calanoid copepods Acartia clausi Giesbrecht and A. steueri Smirnov: a simple empirical model of daily egg production. J Exp Mar Biol Ecol 50:255-271

Uye SI (1985) Resting egg production as life history strategy of marine planktonic copepods. Bull Mar Sci 37:440-449

Uye SI, Kasahara S, Onbe T (1979) Calanoid copepod eggs in sea-bottom muds. IV. Effects of some environmental factors on the hatching of resting eggs. Mar Biol 51:151-156

Vanderploeg HA, Cavaletto JF, Liebig JR, Gardner WS (1998) Limnocalanus macrurus (Copepoda: Calanoida) retains a marine arctic lipid and life cycle strategy in Lake Michigan. J Plankton Res 20:1581-1597

Verheye HM, Hagen W, Auel H, Ekau W, Loick N, Rheenen I, Wencke P, Jones S (2005) Life strategies, energetics and growth characteristics of Calanoides carinatus (Copepoda) in the Angola-Benguela Front region. S Afr J Mar Sci 27:641-652

Villinski JT, Villinski JC, Byrne M, Raff RA (2002) Convergent maternal provisioning and life-history evolution in echinoderms. Evolution 56:1764-1775

Vinogradov ME (1968) Vertical distribution of the oceanic zooplankton. Israel Program for Scientific Translations, 1970. (Original: Academia Nauk SSSR, Institute Okeanologii)

Virtue P, Nicol S, Nichols PD (1993) Changes in the digestive gland of Euphausia superba during short-term starvation: lipid class, fatty acid and sterol content and composition. Mar Biol 117:441-448

Visser AW, Jónasdóttir SH (1999) Lipids, buoyancy and the seasonal vertical migration of Calanus finmarchicus. Fish Oceanogr 8:100-106

Vogt G (1994) Life-cycle and functional cytology of the hepatopancreastic cells of Astacus astacus (Crustacea, Decapoda). Zoomorphol 114:83-101

Volkman JK, Everitt DA, Allen DI (1986) Some analyses of lipid classes in marine organisms, sediments and seawater using thin-layer chromatography - flame ionization detection. J Chromatogr 356:147-162

Walker A, Ando S, Lee RF (2003) Synthesis of a high-density lipoprotein in the developing blue crab (Callinectes sapidus). Biol Bull 204:50-56

Ward P, Shreeve RS, Cripps GC (1996) Rhincalanus gigas and Calanus simillimus: Lipid storage patterns of two species 
of copepod in the seasonally ice free zone of the Southern Ocean. J Plankton Res 18:1439-1454

Williams R, Conway DVP (1988) Vertical distribution and seasonal numerical abundance of the Calanoidae in oceanic waters southwest of the British Isles. Hydrobiology 167/168:259-266

Williams R, Conway DVP, Collins NR (1987) Vertical distributions of eggs, nauplii and copepodites of Calanus helgolandicus (Copepoda: Crustacea) in the Celtic Sea. Mar Biol 96:247-252

Wright SH, Ahearn GA (1997) Nutrient absorption in invertebrates. In: Dantzler WH (ed) Handbook of physiology, Vol II. Oxford University Press, New York, p 1137-1205

Yayanos AA, Benson AA, Nevenzel JC (1978) The pressurevolume-temperature (PVT) properties of a lipid mixture from a marine copepod Calanus plumchrus: implications

Editorial responsibility: Otto Kinne (Editor-in-Chief), Oldendorf/Luhe, Germany for buoyancy and sound scattering. Deep-Sea Res 25: $257-268$

Yuneva TV, Shchepkina AM, Schul'man G, Mel'nikov VV (1993) Lipid composition of euphausiids in the Equatorial Atlantic Ocean. Hydrobiologia 29:61-67

Youngbluth MJ, Kremer P, Bailey TH, Jacoby CA (1988) Chemical composition, metabolic rates and feeding behavior of the midwater ctenophore Bathocyroe fosteri. Mar Biol 98:87-94

Zhou S, Ackman RG, Morrison C (1996) Adipocytes and lipid distribution in the muscle tissue of Atlantic salmon (Salmo salar). Can J Fish Aquat Sci 53:326-332

Zillioux EJ, Gonzalez JG (1972) Egg dormancy in a neritic calanoid copepod and its implications to overwintering in boreal water. In: Battaglia B (ed) Proc 5th Eur Mar Biol Symp. Piccin Editore, Padova, p 217-230

Submitted: March 8, 2005; Accepted: August 4, 2005

Proofs received from author(s): December 23, 2005 